\title{
Assessing the contribution of simultaneous heat and power generation from geothermal plants in off-grid municipalities
}

Weinand, Jann Michael; McKenna, Russell; Kleinebrahm, Max; Mainzer, Kai

Published in:

Applied Energy

Link to article, DOI:

10.1016/j.apenergy.2019.113824

Publication date:

2019

Document Version

Peer reviewed version

Link back to DTU Orbit

Citation (APA):

Weinand, J. M., McKenna, R., Kleinebrahm, M., \& Mainzer, K. (2019). Assessing the contribution of simultaneous heat and power generation from geothermal plants in off-grid municipalities. Applied Energy, 255, [113824]. https://doi.org/10.1016/j.apenergy.2019.113824

\section{General rights}

Copyright and moral rights for the publications made accessible in the public portal are retained by the authors and/or other copyright owners and it is a condition of accessing publications that users recognise and abide by the legal requirements associated with these rights.

- Users may download and print one copy of any publication from the public portal for the purpose of private study or research.

- You may not further distribute the material or use it for any profit-making activity or commercial gain

- You may freely distribute the URL identifying the publication in the public portal 


\title{
Assessing the contribution of simultaneous heat and power generation from geothermal plants in off-grid municipalities
}

\author{
Jann Michael Weinand ${ }^{1}$, Russell McKenna ${ }^{2}$, Max Kleinebrahm ${ }^{1}$, Kai Mainzer ${ }^{1}$ \\ ${ }^{1}$ Chair of Energy Economics, Karls ruhe Institute for Technology, Germany \\ 2 DTU Management Engineering, Technical University of Denmark, Denmark \\ Corresponding author: Jann Michael Weinand, jann.weinand@kit.edu, +49 72160844444
}

\begin{abstract}
A growing number of German municipalities are striving for energy autonomy. Geothermal plants are increasingly constructed in municipalities in order to exploit the high hydrothermal potential. This paper analyses the potential contribution of simultaneous geothermal power and heat generation in German municipalities to achieving energy autonomy. A linear regression estimates the achievable hydrothermal temperatures and the required drilling depths. Technical restrictions and cost estimations for geothermal plants are implemented within an existing linear optimisation model for municipal energy systems. Novel modelling approaches, such as optimisation with variable drilling depths, are developed. The new approach is validated with data from existing geothermal plants in Germany, demonstrating a Root Mean Squared Error of about $15 \%$. Eleven scenarios show that achieving energy autonomy is associated with at least $4 \%$ additional costs, compared to scenarios without it. The crucial role of geothermal plants in providing base load heat and power to achieve energy autonomy is demonstrated. The importance of simultaneous modelling of electricity and heat generation in geothermal plants is also evident, as district heating plants reduce the costs, especially in municipalities with high hydrothermal potential. Further work should focus on the optimal spatial scale of the system boundaries and the impact of the temporal resolution of the analysis on the costs for achieving energy autonomy.
\end{abstract}

\section{Highlights}

- Analysis of hydrothermal potential in German municipalities

- Optimisation of simultaneous geothermal heat and electricity generation

- Drilling depth and hydrothermal temperature are implemented endogenously

- Integration of geothermal plants in a holistic energy system optimisation

- Geothermal plants reveal a potential for cost reduction in off-grid municipalities

Keywords: mixed-integer linear optimisation, geothermal plant, hydrothermal potential, variable drilling depth, energy autonomy 


\section{Nomenclature}

\begin{tabular}{|c|c|c|}
\hline $\begin{array}{l}\text { Variable/ } \\
\text { Parameter }\end{array}$ & Description & Unit \\
\hline$A_{D}$ & Area for the w ell site & $\mathrm{m}^{2}$ \\
\hline$A_{e l}$ & Area for the ORC plant & $\mathrm{m}^{2}$ \\
\hline As & Area for the 3D seismology & $\mathrm{m}^{2}$ \\
\hline$A_{t h}$ & Area for the district heating plant & $\mathrm{m}^{2}$ \\
\hline$b D, 1900$ & w hether the drilling depth is betw een $0 \mathrm{~m}$ and $1900 \mathrm{~m}$ (binary) & - \\
\hline$b D, 3250$ & w hether the drilling depth is betw een $1900 \mathrm{~m}$ and $3250 \mathrm{~m}$ (binary) & - \\
\hline$b D, 3850$ & w hether the drilling depth is larger than $3250 \mathrm{~m}$ (binary) & - \\
\hline$b D, i$ & w hether the drilling depth is betw een $(\mathrm{i}-1) \cdot 1000 \mathrm{mand} \mathrm{i} \cdot 1000 \mathrm{~m}$ (binary) & - \\
\hline bDHP & whether the district heating plant is built (binary) & - \\
\hline bDHP,op & whether the district heating plant is in operation or not (binary) & - \\
\hline$b D H, S, i$ & w hether district heating should cover up to $\mathrm{i} \cdot 10 \%$ of the heat demand of the municipality (binary) & - \\
\hline$b G P$ & whether the geothermal plant is built (binary) & - \\
\hline$b P P$ & whether the ORC plant is built (binary) & - \\
\hline$C_{1}$ & Investment for feasibility study and preliminary planning & $€$ \\
\hline $\mathrm{C}_{2}$ & Tnvestment for properties and infrastructure & $€$ \\
\hline $\mathrm{C}_{3}$ & Tnvestment for exploration of the reservoir & $€$ \\
\hline $\mathrm{C}_{4}$ & Investment for production w ell pump & $€$ \\
\hline $\mathrm{C}_{5}$ & Tnvestment for thermal w ater system(above-ground) & $€$ \\
\hline$C_{6}$ & Investment for pow er generation plant & $€$ \\
\hline$C_{7}$ & Investment for district heating system & $€$ \\
\hline C8 & Investment for project management, control and finance planning as w ell as other investments & $€$ \\
\hline$C_{D}$ & Costs for the drilling w ork and the construction and recultivation of the w ell site & $€$ \\
\hline$C_{D R}$ & Annual costs for working fluid and other demand related-resources & $€ / a$ \\
\hline CDW & Costs for the drilling w ork & $€$ \\
\hline CFS & Costs for the feasibility study & $€$ \\
\hline$C_{G I}$ & Costs for geochemical investigations & $€$ \\
\hline CHT & Costs for hydraulic tests & $€$ \\
\hline$C L$ & Annuallabour costs & $€ / a$ \\
\hline COP & Annual other operating costs, e.g. costs for operating of seismic monitoring & $€ / a$ \\
\hline Cov & Annual variable costs for insurance and legal assistance & $€ / a$ \\
\hline$C_{P}$ & Cost for properties in German municipalities & $€$ \\
\hline$C_{P P}$ & $\begin{array}{l}\text { Costs for the preliminary planning of the pow er generation plant and the above-ground plant } \\
\text { components }\end{array}$ & $€$ \\
\hline$C p, w$ & Mean heat capacity of the geothermal w ater & $\frac{\mathrm{kJ}}{\mathrm{kg} \cdot \mathrm{K}}$ \\
\hline CST & Costs for stimulation & $€$ \\
\hline CuP & Costs for the underground planning & $€$ \\
\hline$d D$ & Distance betw een the production and the injection w ell & $\mathrm{m}$ \\
\hline Del & Electricity demand in the municipality & $\mathrm{kW}$ \\
\hline Del,total & Sum of electricity demand in the municipality and electricity consumption of the feed pump & $\mathrm{kW}$ \\
\hline Dheat, total & Total heat demand of the municipality in a time step & $\mathrm{kW}$ \\
\hline$D_{p}$ & Percentage of electricity consumption of the feed pump in geothermal pow er plants & $\%$ \\
\hline Dpump & Eectricity consumption of the feed pump & $\mathrm{kW}$ \\
\hline$M$ & Large number & - \\
\hline$P_{e l}$ & Pow er generation of the geothermal ORC plant in a time step & $\mathrm{kW}$ \\
\hline$P_{e l, \max }$ & Nominal pow er of the ORC plant & $\mathrm{kW}$ \\
\hline Ppump & Nominal pow er of the feed pump & \\
\hline$\dot{Q}_{t h}$ & Heat generation of the geothermal district heating plant in a time step & $\mathrm{kW}$ \\
\hline$\dot{Q}_{t h, \max }$ & Nominal pow er of the district heating plant & $\mathrm{kW}$ \\
\hline$r z$ & Range of a section for the drilling depth & $\mathrm{m}$ \\
\hline$\Delta T$ & Temperature gradient & ${ }^{\circ} \mathrm{C} / \mathrm{m}$ \\
\hline$T_{a}$ & Annual mean ambient temperature & ${ }^{\circ} \mathrm{C}$ \\
\hline TDHP, return & Temperature of the geothermal $w$ ater after the heat transfer to the district heating system & ${ }^{\circ} \mathrm{C}$ \\
\hline TDH, return, min & Minimum return temperature of the district heating system & ${ }^{\circ} \mathrm{C}$ \\
\hline$T D H, \min$ & Minimum forward temperature of the district heating system & ${ }^{\circ} \mathrm{C}$ \\
\hline$T D H$,pinch & Pinch temperature of the heat exchange to the district heating system & ${ }^{\circ} \mathrm{C}$ \\
\hline
\end{tabular}




\begin{tabular}{|c|c|c|}
\hline TORC, $\min$ & Minimum temperature of the geothermal w ater after the heat transfer to the ORC plant & ${ }^{\circ} \mathrm{C}$ \\
\hline TORC, out & $\begin{array}{l}\text { Temperature of the geothermal } w \text { ater after the heat transfer to the ORC plant and before the heat } \\
\text { transfer to the district heating system }\end{array}$ & ${ }^{\circ} \mathrm{C}$ \\
\hline TPW & Hydrothermal temperature in the production w ell in a time step & ${ }^{\circ} \mathrm{C}$ \\
\hline$T P W, \max$ & Maximum hydrothermal temperature in the production w ell (wellhead temperature) & ${ }^{\circ} \mathrm{C}$ \\
\hline$\dot{V}_{B}$ & Mean volumetric flow rate in the production w ell & $1 / \mathrm{s}$ \\
\hline$Z D$ & Drilling depth & $\mathrm{m}$ \\
\hline$Z D, 1900$ & Drilling depth, if drilling is up to $1900 \mathrm{~m}$ at maximum & $\mathrm{m}$ \\
\hline$Z D, 3250$ & Drilling depth, if drilling is up to $3250 \mathrm{~m}$ at maximum & $\mathrm{m}$ \\
\hline$Z D, 3850$ & Drilling depth, if drilling is above $3250 \mathrm{~m}$ & $\mathrm{~m}$ \\
\hline$Z D, 1$ & Drilling depth, if drilling is up to $1000 \mathrm{~m}$ at maximum & $\mathrm{m}$ \\
\hline$Z D, 2$ & Drilling depth, if drilling is up to $2000 \mathrm{~m}$ at maximum & $\mathrm{m}$ \\
\hline$Z D, 3$ & Drilling depth, if drilling is up to $3000 \mathrm{~m}$ at maximum & $\mathrm{m}$ \\
\hline$Z D, 4$ & Drilling depth, if drilling is up to $4000 \mathrm{~m}$ at maximum & $\mathrm{m}$ \\
\hline$Z D, 5$ & Drilling depth, if drilling is up to $5000 \mathrm{~m}$ at maximum & $\mathrm{m}$ \\
\hline$\rho w$ & Mean density of the geothermal $w$ ater & $\mathrm{kg} / \mathrm{l}$ \\
\hline$\eta$ el & Efficiency of the ORC plant & - \\
\hline$\eta$ pump & Efficiency of the feed pump & - \\
\hline$\eta$ th & Efficiency of the geothermal district heating plant & - \\
\hline
\end{tabular}




\section{Introduction}

The radical change in the energy sector due to ambitious national targets in energy policy is characterised in particular by the expansion of renewable energies. Renewable energies are mainly utilised decentrally due to their characteristics. Therefore, municipalities are often referred to as the driving force behind the energy transition. This particularly applies to Germany, where the decentralised structure also applies to the owners and operators of energy plants: private individuals increasingly invest in renewable energy systems or form so-called citizen-energy cooperatives (McKenna 2018). The majority of regenerative plants in Germany are actually owned and operated by private individuals, farmers and communities (trend:research 2017). This development is due to various motivations: among other things, citizens intend to play an active role in energy supply and to be less dependent on central markets and structures (e.g. Boon \& Dieperink 2014). For homeowners, energy autonomy is one of the main factors that drives them to install renewable energies (Engelken et al. 2018).

Besides energy autonomy for homeowners, the concept of municipal energy autonomy (McKenna et al. 2017) has become established, which is employed here to also include energy autarky (Müller et al. 2011), self-sufficiency (Balcombe et al. 2015) and integrated community energy systems (Koirala et al. 2016). Alone the number of terms for this concept illustrates the diversity within the literature, which also extends to its definition. Three rough distinctions are made between complete energy autonomy (i.e. off-grid), net or balanced energy autonomy, whereby local supply equals or exceeds demand on an annual basis, and a tendency towards higher energy autonomy through decentralised renewables (McKenna et al. 2015). The extensive survey of Engelken et al. (2016) shows that the majority of municipalities with energy autonomy aspirations strive for balanced energy autonomy and the focus is usually on electrical energy. This can also be observed by analysing the energy project "100\%Renewable-Energy-Communities", in which the participating municipalities strive for energy autonomy ${ }^{1}$. The exponential development of those projects since 1995 indicates that an increasing number of German municipalities is striving for energy autonomy. The 1,300 municipalities of the project correspond to $12 \%$ of all municipalities in Germany and account for $15 \%$ of the population.

According to the authors' knowledge, only one entire municipality in Germany strives for complete energy autonomy, namely Bordelum in Schleswig Holstein (Alt 2017). Another example for complete energy autonomy is the village Feldheim, which is a part of the municipality Treuenbrietzen. A study of the impacts of autonomy in this village showed that, after the energy system transition every inhabitant was in an "economically more favourable situation" than before (Mundaca et al. 2018). However, balanced energy autonomy could make network expansion even more essential and also make new allocation systems for grid fees necessary (McKenna 2018). This could result in economic inefficiencies compared to the established system of centralised generation, transmission and distribution (Jägemann et al. 2013). The present study therefore considers complete energy autonomy, as this state could be advantageous for the energy system. In other words, no imports are possible and the electricity and heat demand must be covered by local renewable energies.

These renewable energies already account for 33\% of electricity generation in Germany in 2017 (Statistisches Bundesamt 2017a). In contrast, the proportion of renewable heat supply is much lower at around 13\% (UBA 2018a). The renewable energies include around $55 \mathrm{GW}$ of wind energy (on- and offshore), $42 \mathrm{GW}$ photovoltaic (PV) systems, about $7 \mathrm{GW}$ of bioenergy (BMWi 2017) and $39 \mathrm{MW}$ of deep geothermal energy (UBA 2018a). In comparison to the other renewable energies, relatively little electricity is generated by geothermal plants (GTPs) despite the fact that deep geothermal energy could make a major contribution to reducing greenhouse gas emissions. However, the relative growth from $7 \mathrm{MW}_{\text {el }}$ to $39 \mathrm{MW}_{\text {el }}(+450 \%)$ in geothermal power generation in Germany between 2010 and 2017 is one

\footnotetext{
${ }^{1}$ Own determination with data from the websites of the municipalities as well as the following websites, among others: http://www.kommunal-erneuerbar.de/startseite.html and http://www.100-ee.de/.
} 
of the highest in the world (Bertani 2016). The currently (2017) installed 30 GTPs in Germany generate about 155 GWh of electricity (UBA 2018a) and 1.3 TWh of heat (Agemar et al. 2018) annually, which is generally used for district heating (DH) applications (Weber et al. 2016). The locations of the 30 GTPs are shown in Figure 2. The electricity generation is still very low compared to the available resources with a technical potential of 4,155 TWh per year (Jain et al. 2015). This potential is significantly higher than the 654 TWh of gross electricity generated in 2017 in Germany (UBA 2018b).

The use of GTPs could be relevant for municipal energy autonomy efforts due to the following advantages: on the one hand, in contrast to many alternative renewable energy plants, the plants are able to provide heat and electricity as base load. As the Literature Review in section 2 demonstrates, the costs of energy autonomy are very high due to the volatile generation of electricity by PV and wind and the resulting need for high storage capacities. In addition, resources for the use of biomass or gas networks are not available in every municipality. In this case, the use of the DH generated by the GTPs would be particularly important. Furthermore, GTPs emit the lowest amount of pollutants during the life cycle of the plant after hydropower (Purkus \& Barth 2011).

The objective of this study is to answer the following research questions, developed from an analysis of existing literature (cf. section 2):

- Could the high costs for off-grid municipal energy systems be reduced through the use of geothermal plants?

- Is it sufficient to consider only the electricity generation of the geothermal plant or would the use of the geothermal heat in district heating networks create an additional benefit?

To answer these research questions, a generic approach for the modelling of GTPs in municipalities is developed, which is included in a holistic ${ }^{2}$ energy system optimisation. In order to ensure the transferability of the method, a novel modelling approach for the simultaneous generation of electricity and heat as well as the calculation of costs for GTPs is demonstrated. Furthermore, a basis for the assessment of the hydrothermal potential in each German municipality is provided, which also serves as input for the optimisation model. The hydrothermal potential is determined by the achievable temperature of the water in aquifers at depths of up to $5 \mathrm{~km}$. The hydrothermal potential therefore also determines the geothermal potential (i.e. electricity or heat generation potential), since the temperature of the hydrothermal fluid serves as a heat source for the geothermal plants in the present study. The approach is not intended to replace the detailed assessment of the hydrothermal potential on site, but is suitable to demonstrate a possible utilisation of this potential. In addition to the transferability of the approach, the effect of GTPs on the costs and emissions of energy autonomous municipal energy systems is investigated in several municipalities by energy system optimisations. Thereby the focus is on the residential sector. On the one hand, the focus of the energy projects mentioned above is on this sector. On the other hand, this sector can be implemented most precisely due to the comprehensive data availability.

The paper is structured as follows. Section 2 provides an overview of the literature and clarifies the context of this paper. Section 3 then explains the methodology, before sections 4 and 5 present and discuss the results. The paper concludes with a summary and conclusions in section 6 .

\section{Literature review}

In this section, the novelty of the study is demonstrated by discussing peer-reviewed literature on energy autonomy in municipalities (section 2.1) and on the optimisation of GTPs (section 2.2).

\footnotetext{
2 We mean by "holistic" that not only the geothermal plant its elf is optimised. Instead, the geothermal plant is onlya small part of the overall optimisation, in which the costs for energy supply in municipalities are minimised and other technologies and measures can be applied alongside / instead of the geothermal plant.
} 


\subsection{Municipal energy autonomy}

Several case studies have already examined the feasibility of municipal energy autonomy (cf. Table 1). In this context, only studies in which at least balanced autonomy is investigated are referred to. Balanced autonomy of a region is examined in Scheffer (2008), Schmidt et al. (2012), Peura et al. (2018) and Burgess et al. (2012). Scheffer (2008) focuses on a rural model region with 10,000 inhabitants and agriculture as well as trade and commerce, but without large-scale industry. High investments are necessary for the balanced energy autonomy and storable biomass is highlighted as the most important energy source for achieving this status. Schmidt et al. (2012) investigate the advantages and disadvantages of energy autonomy compared to conventional energy supply in Sauwald, a rural region with 21,000 inhabitants in Austria. The study comes to the conclusion that attaining energy autonomy implies a decline in local production of food and feed as well as high costs for consumers. Peura et al. (2018) investigate the potential economic effects of balanced energy autonomy in the municipalities of Perho and Jepua in Finland and take into account the consumption sectors of households, industry, transport and commerce. The study finds that energy autonomy can be technically feasible and economically advantageous in rural areas. Finally, the study by Burgess et al. (2012) explores the Marston Vale region in the UK, which in particular would have to import heat energy and fuels, while a large proportion of its electricity needs could be covered by energy from the region itself.

Complete municipal energy autonomy, on the other hand, is investigated in Peter (2013), Jenssen et al. (2014) and Woyke \& Forero (2014).The suitability of a rural settlement structure for complete energy autonomy is analysed in Peter (2013), who demonstrates that renewable energies could cover the electricity demand of an "example village" with 3,850 inhabitants but with tremendous storage costs. Jenssen et al. (2014) conclude that complete energy autonomy is technically achievable in an "average" German municipality through the "Bioenergy Village" approach, albeit at high costs. Woyke \& Forero (2014) assess complete energy autonomy in Pellworm, an island municipality in Germany with 1,100 inhabitants, which has been regarded as a model location for the construction of renewable energies. Despite the fact that energy supply exceeds demand, complete energy autonomy is not possible with the current energy system in Pellworm due to grid restrictions.

Overall, it appears that energy autonomy can only be achieved at high cost. In the case of complete energy autonomy, this is related to high storage costs. The present study considers all energy supply technologies applied in the presented literature except for solar thermal (cf. Table 1). So far, none of the studies on municipal energy autonomy includes a possible contribution from GTPs, which could reduce the high storage costs through base load capacity.

Table 1: Municipal energy autonomy studies and the considered energy supply technologies (BE = Bioenergy, WE $=$ Wind energy, $P V=$ Photovoltaics, $S T=$ Solar thermal energy, $G E=$ Geothermal energy, $A H P=$ Air-source heat pump, $G H P=$ Ground-source heatpump).

\begin{tabular}{|c|c|c|c|c|c|c|c|}
\hline \multirow[t]{2}{*}{ Study } & \multicolumn{5}{|c|}{$\begin{array}{c}\text { Considered energy supply } \\
\text { technologies }\end{array}$} & \multirow[t]{2}{*}{$\begin{array}{l}\text { Type of energy } \\
\text { autonomy }\end{array}$} & \multirow[t]{2}{*}{ Context } \\
\hline & $\mathrm{BE}$ & WE & PV & ST & GE & & \\
\hline Burgess etal. (2012) & $\checkmark$ & $\sqrt{ }$ & $\sqrt{ }$ & $\sqrt{ }$ & $\mathrm{GHP}$ & Balanced & Region in UK \\
\hline Jenssen etal. (2014) & $\checkmark$ & $x$ & $x$ & $x$ & $x$ & Complete & German "Bioenergyvillage" \\
\hline Peter (2013) & $x$ & $\bar{\checkmark}$ & $\sqrt{ }$ & $\checkmark$ & GHP & Balanced and complete & German village \\
\hline Peura et al. (2018) & $\checkmark$ & $\sqrt{ }$ & $x$ & $x$ & $x$ & Balanced & Finnish municipalities \\
\hline Scheffer (2008) & $\checkmark$ & $\sqrt{ }$ & $\sqrt{ }$ & $\sqrt{ }$ & $x$ & Balanced & Rural German region \\
\hline Schmidtet al. (2012) & $\checkmark$ & $x$ & $\checkmark$ & $\checkmark$ & GHP & Balanced & Rural Austrian region \\
\hline Woyke \& Forero (2014) & $\checkmark$ & $\sqrt{ }$ & $\bar{\checkmark}$ & $x$ & $x$ & Balanced and complete & German Island \\
\hline This study & $\checkmark$ & $\checkmark$ & $\checkmark$ & $x$ & $\begin{array}{l}\text { AHP/GHP } \\
\text { and GTPs }\end{array}$ & Complete & German municipalities \\
\hline
\end{tabular}




\subsection{Geothermal plant optimisation}

In most studies on GTPs, process parameters are optimised, such as power output or various efficiencies of the plant (cf. 43 summarised studies in Table $A 1^{3}$ in the Appendix). Usually only electricity generation is considered. Van Erdeweghe et al. (2018) and Marty et al. (2018) alone consider a combined power and heat production, whereby in Van Erdeweghe et al. (2018) the focus is on the optimisation of the power generation as well. Furthermore, in most cases low brine temperatures are investigated, which are also present in Germany. Only in very few cases the investigated energy system includes not only the GTP but a more extensive system with other energy supply technologies. These cases of interest are examined in more detail in the following.

Østergaard et al. (2010) investigate the feasibility of supplying the municipality of Aalborg in Denmark with renewable energy through a combination of deep geothermal heat, wind power plants and biomass. GTPs are used for heat generation only. The results of the simulations show that these technologies cannot cover the demand of Aalborg in every hour and that energy has to be imported instead. The study of Østergaard \& Lund (2011) on Frederikshavn in Denmark, in which the city's energy demand should be $100 \%$ renewable, also takes deep geothermal energy into account as a heat generation plant with a district heating network (DHN). The simulation includes wind turbines to cover the electricity demand, therefore a balanced electricity autonomy is considered. The study shows that the operation of the GTP and the DHN reduces the energy imports of Frederikshavn. In the study of Sveinbjörnsson et al. (2017), the municipality of Sønderberg in Denmark is considered, which is aiming for zero net $\mathrm{CO}_{2}$ emissions by 2029. Exactly as in Østergaard \& Lund (2011), the GTP is combined with an absorption heat pump. The mixed-integer linear optimisation shows that by supplementing combustion with modern energy conversion technologies, the climate targets can be achieved in a cost- and energy-efficient manner. The most relevant paper for the analysis carried out in the present study is Marty et al. (2018). They highlight the relevance of a simultaneous optimisation of the DHN and the organic rankine cycle (ORC) of a GTP. However, the model in their study is not automatically applicable to any location, as hydrothermal temperatures as well as distances to heat consumers have to be specified manually and geographical conditions are not considered. Furthermore, only parts of the GTP are optimised and not the entire plant. For example, fixed drilling costs are specified in the optimisation and it is not possible to optimise the depth of the boreholes. Beyond that, the greatest need for improvement lies in the fact that the GTP is optimised without being in an energy system context with competition from other technologies such as $\mathrm{PV}$, wind turbines and biomass plants.

Table 2 summarises the main characteristics of the discussed studies. In the 39 other studies on GTP energy systems from Table A1, only those properties are given for which a clear statement was possible. More detailed information can be found in Table A1. As a summary, the evaluation of the studies demonstrates that GTPs are usually optimised with regard to power generation. This is justified as most studies are technical analyses to optimise parameters of the ORC plant. On the other hand, the ORC system is neglected and only the DH supply is considered when optimising municipal energy systems. Furthermore, only specific municipalities were examined and no attempt was made to generate transferable methods. The following gaps were identified in the review of the literature, which the authors fill with the present study:

1) Development of a generic optimisation model for the optimisation of a GTP, which simultaneously generates electricity and heat. The model also optimises the drilling depth and the related hydrothermal temperature (cf. section 3).

\footnotetext{
${ }^{3}$ Tables, figures and sections in the Appendix are marked with an A before the numbering.
} 
2) Integration of the GTP model in a holistic and transferable 4 energy system optimisation model applicable to every German municipality (cf. section 3.5).

3) Investigation of the economic feasibility of complete municipal energy autonomy including GTPs (cf. section 4).

Table 2: Main characteristics of the geothermal plantoptimisation studies.

\begin{tabular}{|c|c|c|c|c|c|c|}
\hline Study & Methodology & $\begin{array}{l}\text { Focus on } \\
\text { DH and / } \\
\text { or power }\end{array}$ & $\begin{array}{l}\text { Variable } \\
\text { temperature } \\
\text { and drilling } \\
\text { depth }\end{array}$ & $\begin{array}{l}\text { Optimisation } \\
\text { of the district } \\
\text { heating } \\
\text { network }\end{array}$ & $\begin{array}{l}\text { Easily } \\
\text { transfer- } \\
\text { able? }\end{array}$ & $\begin{array}{l}\text { Investigated } \\
\text { energy } \\
\text { system }\end{array}$ \\
\hline 39 other studies (section A1) & $\begin{array}{l}\text { Mainly } \\
\text { optimisation }\end{array}$ & Power & $x$ & $x$ & - & GTP \\
\hline Østergaard et al. (2010) & Simulation & DH & $x$ & $x$ & $x$ & Municipality \\
\hline Østergaard \& Lund (2011) & Simulation & $\mathrm{DH}$ & $x$ & $x$ & $x$ & Municipality \\
\hline Sveinbjörnsson et al. (2017) & Optimisation & DH & $x$ & $x$ & $x$ & Municipality \\
\hline Marty et al. (2018) & Optimisation & Both & $x$ & $\checkmark$ & $x$ & $\begin{array}{l}\text { GTP and few } \\
\text { consumers }\end{array}$ \\
\hline This study & Optimisation & Both & $\checkmark$ & $\checkmark$ & $\checkmark$ & Municipality \\
\hline
\end{tabular}

\section{Methodology}

Energy system analyses in municipalities usually require a lot of data. In addition, the possible measures have to be adapted to the individual municipality. The methodology in this study aims to be transferable and applicable to each municipality without further effort ${ }^{4}$. This means that no data needs to be collected. Instead, only the name of the municipality needs to be provided and all required input data are determined automatically. This approach enables the investigation of several municipalities and the identification of the impacts of different prerequisites in the municipalities on the optimal energy systems. First of all, this methodological section gives an overview of the general approach (section 3.1). In section 3.2 the achievable hydrothermal temperatures at certain locations in Germany as well as the varying depths at which these temperatures can be found, depending on the location, are demonstrated. Afterwards, the most important model equations for representing a GTP are presented in section 3.3 before the economic assessment of a GTP is considered in section 3.4. Finally, section 3.5 explains the integration of the developed GTP model into the holistic energy system model. An overview of the existing methodology and the extensions presented in this study are given in Figure 1.

\subsection{General approach}

For the determination of the optimal municipal energy system design in this study, the "Renewable Energies and Energy Efficiency Analysis and System OptimisatioN" (RE $\left.{ }^{3} A S O N\right)$ model is used and further extended (Mainzer 2019, cf. Figure 1). In the first step of the model ("Input data determination") the required input data are calculated with the use of a Java model (Eclipse). The input data are applied in the second step, the actual optimisation model, which is implemented by using the General Algebraic Modeling System (GAMS). The RE ${ }^{3} A S O N$ model consists of several parts, which provide transferable methods for determining the existing technologies, infrastructure, the heat and electricity demand of residential buildings as well as the potential and associated costs for energy supply from photovoltaic (PV), wind and biomass in an arbitrary location. Due to the transferability, this model is applied in the

\footnotetext{
4 This refers to the developed methods. Some assumptions, especially about certain parameter values, are not necessarily transferable to every municipality (cf. section 5 ).
} 
present study, as various municipalities in different locations are investigated. RE ${ }^{3} A S O N$ further provides a deterministic model of optimal investment and dispatch for new energy conversion technologies at the community level. In the mixed integer linear program (MLP), the optimal technology investment and unit commitment of all technologies as well as energy flows between districts is identified. The model serves to cope with the complexity resulting from the number and combinations of the individual measures and their dependencies that would otherwise not be feasible. Included in the model are the above-mentioned energy supply technologies as well as measures such as insulation, heating technologies or appliances. The municipality under consideration is divided into districts, in which buildings are grouped into building types according to the TABULA building typology (IWU 2015). The spatial resolution consists of these districts as nodes to which the input, like heat and power demand, is assigned. In addition, the existing infrastructure such as gas and electricity grids are identified. However, no DHNs could be built in the old version of the model. Therefore, it is extended for the utilisation of district heat from the GTP (cf. section 3.5). In the present study, the model is used to perform a long-term energy system optimisation (from 2015 to 2030), whereby each 5 th year is modelled explicitly and divided into 108 time slices (4 seasons, 3 day types, 9 time slices within each day). An energy system must ensure security of supply even under extreme conditions of energy demand and climatic conditions (Petrakopoulou et al. 2016). Therefore, one extreme day is designed for every season. In the extreme days, the energy demands in the residential buildings reach the maximum values of the originally determined demand load profiles for the respective season and no solar radiation or wind is present.

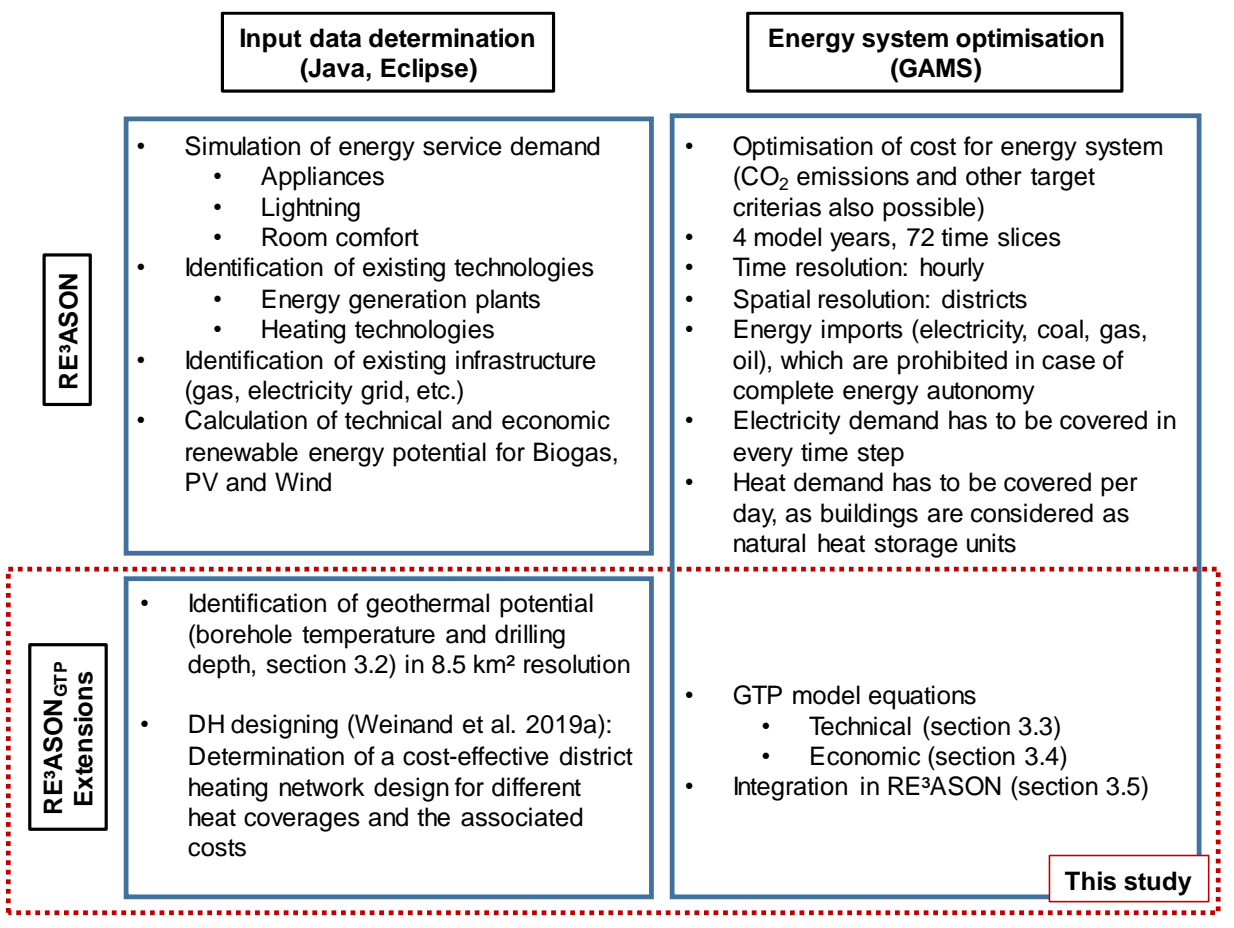

Figure 1: Overview of $R E^{3} A S O N$ and the extensions developed in the present study.

The model can be used to minimise total discounted system costs, $\mathrm{CO}_{2}$ emissions or energy imports of the municipal energy system. The calculation of the potential of PV, wind and biomass is briefly explained in the following, for further information about the model including the mathematical model formulation the reader is referred to McKenna et al. (2018) and Mainzer (2019). In order to determine the PV potential, OpenStreetMap is used to identify building data and roof areas (OpenStreetMap contributors 2018). Satellite data is used to detect roof type and orientation. In addition, a methodology based on neural networks detects already installed PV modules. More information about the PV potential calculation can be found in Mainzer et al. (2017). The potential calculation of wind turbines uses minimum distance specifications to, for example, settlements or airports to determine the number of wind turbines that can be placed in the municipality. Based on the minimum levelized cost of electricity 
(LCOE), the wind turbine type is selected. For wind and PV potential determination, different local climates are also included in the calculation. In the case of biomass plants, the maximum amount of substrates that can be produced on the agricultural and forest areas of the municipality is determined for different types of plants. Implemented plants are waste-to-energy plants, woody biomass combustion plants and biogas plants. The LCOE calculation includes investments as well as transport costs. The amount of energy that can be supplied using the substrates can be divided arbitrarily over the year. The biomass plants, therefore, can be used flexible and can serve peak loads as well as base loads. Results of the input determination for photovoltaics, wind power and biomass as well as for the district heating network for an exemplary municipality can be found in the electronic Appendix. The RE ${ }^{3} A S O N$ model extensions shown in Figure 1 are explained hereafter. The extensions are implemented within the program environment of the existing $\mathrm{RE}^{3} \mathrm{ASON}$ model.

\subsection{Achievable hydrothermal temperature and required drilling depth}

The achievable hydrothermal temperature $T_{P W, \max }$ (wellhead temperature) is based on the values of the Geothermal Information System GeotlS (Agemar et al. 2014). For the present study, the data from the geographical map of Germany in GeotIS were transferred to a CSV file in $8.5 \mathrm{~km}^{2}$ resolution and the vertices of the grid now serve as input for the optimisation model. Figure 2 shows the geographical map of the 11,100 German municipalities with achievable temperatures at a depth of up to $5 \mathrm{~km}$ resulting from the data transfer. The achievable temperatures reach up to $190^{\circ} \mathrm{C}$ and the prevailing pressure conditions in the brine are assumed to be high enough, so that the water does not boil below this temperature. If more than one point of the $8.5 \mathrm{~km}^{2}$ grid is located in the municipality, the mean value of the achievable temperatures is employed. Since the transfer of the data to create the grid with the hydrothermal temperatures required a substantial amount of work, the CSV is provided as supplementary material.

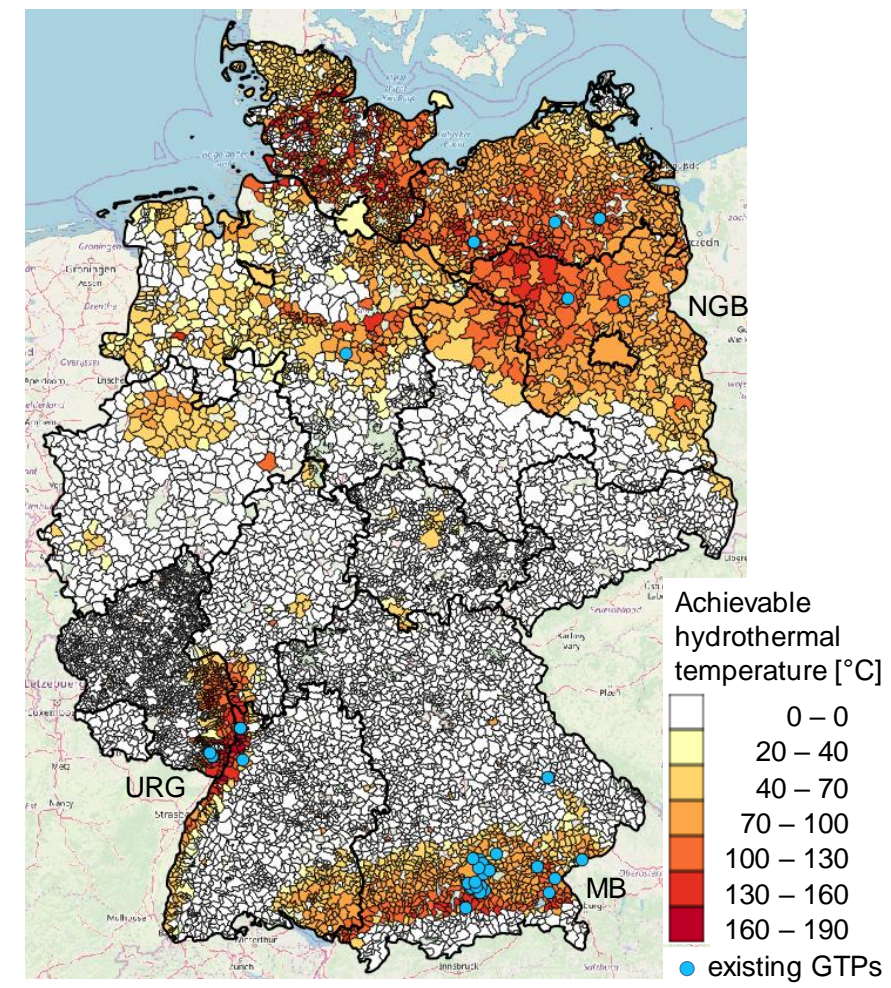

Figure 2: Achievable average hydrothermal temperature $\left({ }^{\circ} \mathrm{C}\right)$ at a depth of up to $5 \mathrm{~km}$ in German municipalities according to Agemar el al. (2014) and locations of GTPs in Germany (blue circles). The background map in this figure and in all of the following figures with background maps is from OpenStreetMap contributors (2018). For a better analysis of the colours in this figure, please refer to the online version of the paper.

As soon as the hydrothermal temperature is known, the required drilling depth $z_{D}$ can be determined. For this purpose, according to Bauer et al. (2014), the mean German temperature gradient of $32{ }^{\circ} \mathrm{C} / \mathrm{km}$ 
is assumed for the South German Molasse Basin (MB) and $35^{\circ} \mathrm{C} / \mathrm{km}$ for the North German Basin (NGB). In the Upper Rhine Graben (URG), on the other hand, the temperature gradients are much higher with $43^{\circ} \mathrm{C} / \mathrm{km}$ on average (locally up to $110^{\circ} \mathrm{C} / \mathrm{km}$, Bauer et al. (2014)), especially in the area up to $3 \mathrm{~km}$ (Agemar et al. 2012). MB, NGB and URG are shown in Figure 2. In order to be able to determine the temperature gradient more precisely, the temperature gradient resulting from the drillings for the GTP in Landau are taken over for the entire URG (Frey \& Milles 2007), but adjusted in such a way that the mean value is $43{ }^{\circ} \mathrm{C} / \mathrm{km}$. This results in the three temperature sections in Figure 3. The temperature gradient $\Delta T$ decreases with depth and adapts to the German average. Above $3,250 \mathrm{~m}$, a constant temperature gradient is assumed.

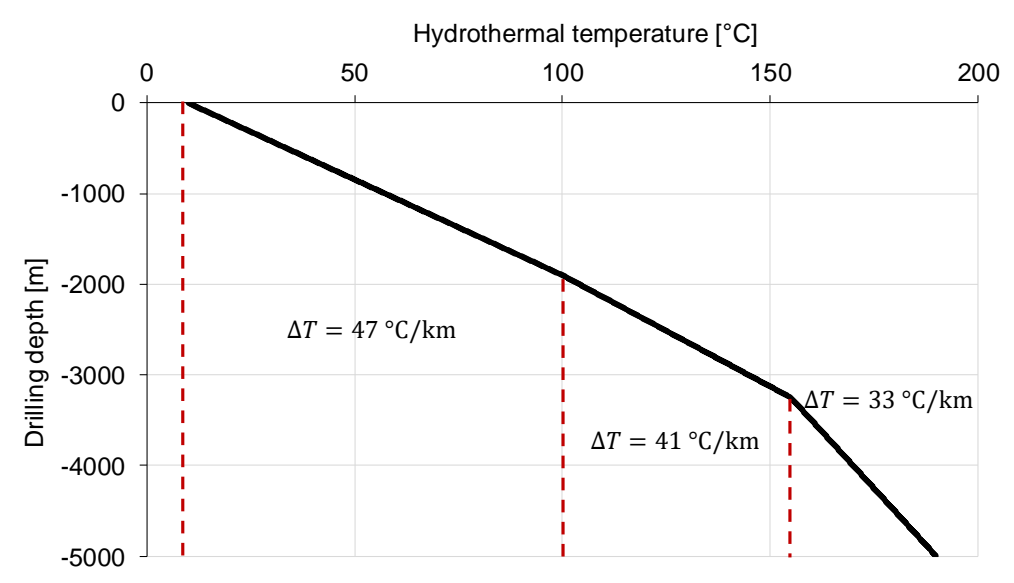

Figure 3: Assumed temperature sections as a function of the drilling depth in the Upper Rhine Graben.

\subsection{GTP model for simultaneous heat and electricity generation}

This section describes the equations used to implement the GTP model. In the equations, variables are shown in bold, the other terms are parameters. Thereby the most important model equations will be described. The authors could provide the complete modeling equations upon request. The schematic illustration of the GTP in Figure 4 is intended to help identify the most important variables and parameters of the model, which are introduced in this section. Since existing DHNs in Germany cannot be identified without further research, it is assumed that no DHN already exists in the municipalities (green field approach).

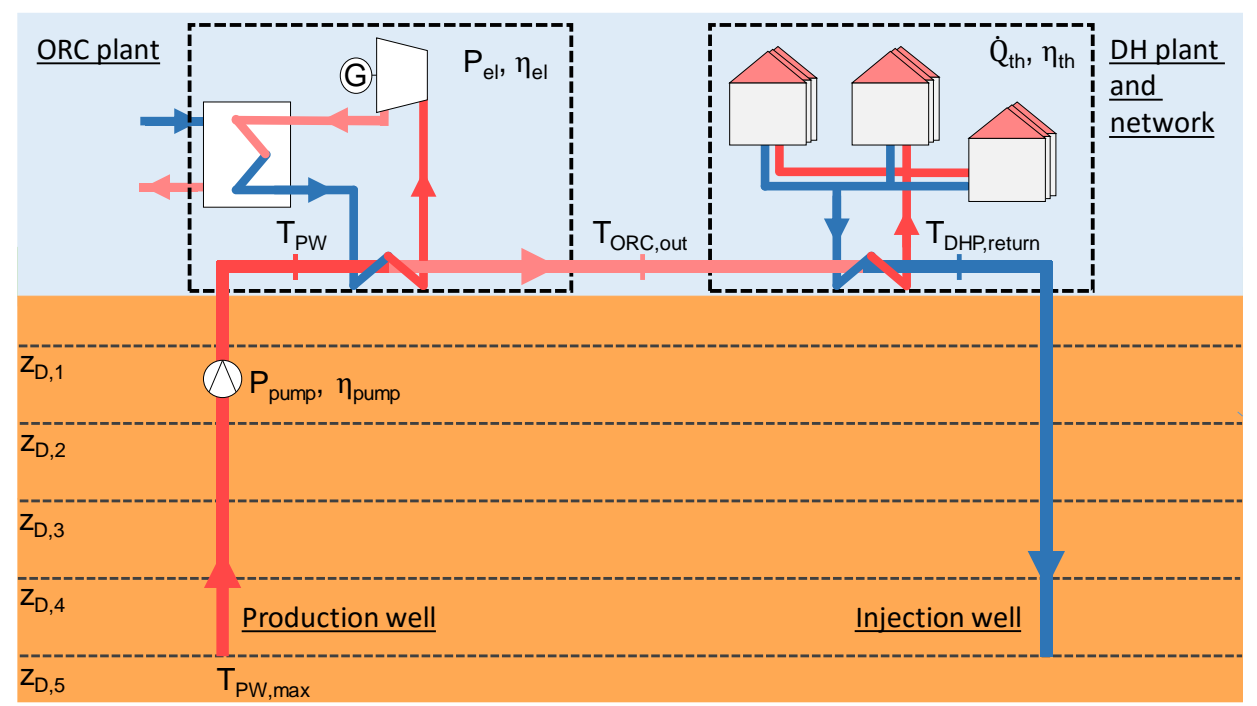

Figure 4: Schematic illustration of the GTP considered in this study. The heat flow in the condenser of the ORC process could be water or air. For a better analysis of the colours in this figure, please refer to the online version of the paper. 
The power generation $P_{e l}$ of the ORC plant and heat generation $\dot{Q}_{t h}$ of the district heating plant (DHP) per time step t can be determined using Eqs. 1-2.

$$
\begin{array}{ll}
\dot{V}_{B} \cdot \rho_{w} \cdot c_{p, w} \cdot\left(\boldsymbol{T}_{\boldsymbol{P W}}(t)-\boldsymbol{T}_{\boldsymbol{O R C}, \boldsymbol{o u t}}(t)\right)=\boldsymbol{P}_{\boldsymbol{e l}}(t) / \eta_{\text {el }} & \forall t \\
\dot{V}_{B} \cdot \rho_{w} \cdot c_{p, w} \cdot\left(\boldsymbol{T}_{\boldsymbol{O R C}, \boldsymbol{o u t}}(t)-\boldsymbol{T}_{\boldsymbol{D H P}, \text { return }}(t)\right)=\dot{\boldsymbol{Q}}_{\boldsymbol{t h}}(t) / \eta_{t h} & \forall t
\end{array}
$$

The maximum possible volumetric flow rate depends on the local geological conditions. Furthermore, in most GTPs the economically and energetically optimal volumetric flow rate is significantly below the maximum possible flow rate, since the installation depth and design of the feed pump depend on the flow rate (Rohloff \& Kather 2011). Therefore, the mean flow rate of the existing deep geothermal projects in Germany of $75 \mathrm{l} / \mathrm{s}$ is used as the volumetric flow rate $\dot{V}_{B}$ in the model (cf. Table A2). The heat capacity $c_{p, w}$ of geothermal water increases from approximately $4.18 \mathrm{~kJ} \cdot \mathrm{kg}^{-1} \cdot \mathrm{K}^{-1}$ at $20^{\circ} \mathrm{C}$ to about $4.45 \mathrm{~kJ} \cdot \mathrm{kg}^{-1} \cdot \mathrm{K}^{-1}$ at $190^{\circ} \mathrm{C}$. In the same temperature interval the water density $\rho_{w}$ decreases from approximately $1 \mathrm{~kg} / \mathrm{l}$ to about $0.9 \mathrm{~kg} / \mathrm{l}$ (Schröder et al. 2015). In this temperature interval, the product of these two coefficients differ by $4 \%$. Therefore, a constant mean heat capacity of $4.31 \mathrm{~kJ}^{\mathrm{kg}} \mathrm{kg}^{-1} \cdot \mathrm{K}^{-1}$ and a mean density of $0.95 \mathrm{~kg} / \mathrm{l}$ are assumed in the following. The GTP is assumed to operate in base load, therefore $P_{e l}$ and $\dot{Q}_{t h}$ are limited in such a way that these take constant values in a season, i.e. four different values per year.

The injection temperatures are known for the power plants Insheim, Dürnhaar and Kirchstockach. No heat is generated in these plants (cf. Table A2). Thus, the efficiency of the ORC plants could be determined with the help of Eq. 1 . The resulting mean value $13 \%$ is assumed for the electrical efficiency $\eta_{e l}$ in the following, which is a relatively high value for binary ORC plants and almost corresponds to the typical efficiency of ORC plants of $16 \%$ (Quoilin et al. 2013). In accordance with Ozgener \& Ozgener (2009), 65\% is assumed for the efficiency $\eta_{\text {th }}$ of the geothermal DH system, including heat exchange and heat losses in the DHN. Thus, the power and heat generation depends only on the temperature in the production well $\mathrm{TPw}_{\mathrm{PW}}$ and the temperature after the heat transfer to the ORC process

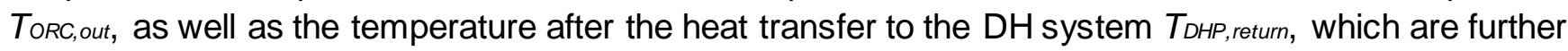
constrained in the following. Based on the values from Zarrouk \& Moon (2014), a minimum output temperature $T_{O R C, \min }$ of $50^{\circ} \mathrm{C}$ is assumed after the heat transfer to the binary power plant. To avoid that the ORC plant is necessarily built, this condition only applies if the binary variable bPp equals 1 (cf. Eq. 3).

$$
\boldsymbol{b}_{\boldsymbol{P P}} \cdot T_{O R C, \min } \leq \boldsymbol{T}_{\boldsymbol{O R C}, \text { out }}(t) \quad \forall t
$$

The same applies to heat extraction for $\mathrm{DH}$ purposes. A conventional DHN is assumed here with a minimum forward temperature $T_{D H, \text { min }}$ of $65^{\circ} \mathrm{C}$ (Lindenberger et al. 2000), a pinch temperature $T_{D H, \text { pinch }}$ of $5{ }^{\circ} \mathrm{C}$ at the heat exchanger and a return temperature $T_{D H P, \text { return of }} T_{D H, \text { return,min }}=55^{\circ} \mathrm{C}$ (Elmegaard et al. 2016). This condition also only applies if the DHP is built $\left(b_{D H P}=1\right)$. In order to ensure that $T_{\text {ORC, out }}$ is not always at least $T_{D H, m i n}+T_{D H, \text { pinch }}=70^{\circ} \mathrm{C}$ in this case, the time-dependent variable $b_{D H P, o p}$ is introduced, which indicates whether heat is generated in a time step or not (cf. Eqs. 4 and 5).

$$
\begin{gathered}
\left(T_{D H, \text { return,min }}+T_{D H, \text { pinch }}\right) \cdot \boldsymbol{b}_{\boldsymbol{D H P , \boldsymbol { p }}}(t) \leq \boldsymbol{T}_{\boldsymbol{D H P}, \text { return }}(t) \quad \forall t \\
\boldsymbol{b}_{\boldsymbol{D H P}, \boldsymbol{o p}}(t) \cdot\left(T_{D H, \text { min }}+T_{D H, \text { pinch }}\right) \leq \boldsymbol{T}_{\boldsymbol{O R C}, \boldsymbol{o u t}}(t) \quad \forall t \\
\boldsymbol{b}_{\boldsymbol{D H} \boldsymbol{P}, \boldsymbol{o p}}(t) \cdot M \geq \boldsymbol{T}_{\boldsymbol{D H P}, \text { return }}(t) \quad \forall t
\end{gathered}
$$

Eq. 6 is introduced to ensure that the temperature $T_{D H, \text { return,min }}$ is maintained. $M$ is a large number which should be as small as possible and at least as large as the maximum value of the restricted variable (Griva et al. 2009), in this case $190^{\circ} \mathrm{C}$. The injection temperature is at least $50^{\circ} \mathrm{C}$ if no energy is used for $\mathrm{DH}$ purposes and $60^{\circ} \mathrm{C}$ otherwise. As described in more detail in section 3.4 , the drilling cost function 
is divided into five sections, to obtain a linear function. Only one of the sections may be selected with the binary variable $b_{D, i}$ (cf. Eq. 7):

$$
\sum_{i=1}^{5} \boldsymbol{b}_{D, i} \leq 1
$$

The selected range then determines the possible minimum and maximum value of the drilling depth $Z D, i$. The range of a section $r_{z}$ in Eqs. 8-10 is set to $1,000 \mathrm{~m}$.

$$
\begin{gathered}
\boldsymbol{b}_{\boldsymbol{D}, \boldsymbol{i}} \cdot(i-1) \cdot r_{z} \leq \boldsymbol{z}_{\boldsymbol{D}, \boldsymbol{i}} \quad \forall i \\
\boldsymbol{b}_{\boldsymbol{D}, \boldsymbol{i}} \cdot i \cdot r_{z} \geq \boldsymbol{z}_{\boldsymbol{D}, \boldsymbol{i}} \quad \forall i \\
\mathbf{z}_{\boldsymbol{D}} \leq 5 * r_{z}
\end{gathered}
$$

For example, if $b_{D, 2}$ is set to 1 , then the drilling depth is in the range of $1,000 \mathrm{~m}$ to $2,000 \mathrm{~m}$. However, since there are now five cost functions for the different sections of the drilling depth $Z D$, only the cost function that has been selected may be used. Therefore, the drilling depth $Z_{D, i}$ is determined for each section, which is zero if the section is not selected (cf. Eq. 11).

$$
z_{D, i}=z_{D} \cdot b_{D, i} \quad \forall i
$$

In the following, the costs can be assigned to the variables $Z_{D, i}$ and $b_{D, i}$ (see section 3.4). The achievable temperature is in turn determined via $Z_{D}$. To avoid that all $b_{D, i}$ and $Z D, i$ are set to zero, the following equation must be added:

$$
\boldsymbol{z}_{\boldsymbol{D}}=\sum_{i=1}^{5} \mathbf{z}_{\boldsymbol{D}, \boldsymbol{i}}
$$

The equation and the defined temperature sections from section 3.2 are used to determine the temperature $T_{\mathrm{PW}, \max }$ of the water in the production well if the investigated municipality is located in the Upper Rhine Graben (cf. Eq. 13).

$$
\begin{gathered}
\left(\frac{\boldsymbol{Z}_{\boldsymbol{D}, \mathbf{1 9 0 0}}}{1,900 \mathrm{~m}}\right) \cdot\left(100{ }^{\circ} \mathrm{C}-T_{a}\right)+T_{a} \cdot \boldsymbol{b}_{\boldsymbol{D}, \mathbf{1 9 0 0}}+\left(\frac{\boldsymbol{Z}_{\boldsymbol{D}, \mathbf{3 2 5 0}}-1,900 \mathrm{~m} \cdot \boldsymbol{b}_{\boldsymbol{D}, \mathbf{3 2 5 0}}}{1,350 \mathrm{~m}}\right) \cdot 55^{\circ} \mathrm{C}+100{ }^{\circ} \mathrm{C} \cdot \boldsymbol{b}_{\boldsymbol{D}, \mathbf{3 2 5 0}} \\
+\left(\frac{\boldsymbol{z}_{\boldsymbol{D}, \mathbf{3 8 5 0}}-3,250 \mathrm{~m} \cdot \boldsymbol{b}_{\boldsymbol{D}, \mathbf{3 8 5 0}}}{600 \mathrm{~m}}\right) \cdot 20^{\circ} \mathrm{C}+155^{\circ} \mathrm{C} \cdot \boldsymbol{b}_{\boldsymbol{D}, \mathbf{3 8 5 0}} \geq \boldsymbol{T}_{\boldsymbol{P} W, \text { max }}
\end{gathered}
$$

The sections of the drilling depth $Z D, 1900, Z D, 3250$ and $Z D, 3850$ to determine the temperature do not correspond to the sections of the drilling depths $Z D, i$ to determine the drilling costs. Therefore, the Eqs. 712 from above have to be replicated for these drilling depth sections as well. To limit the temperature $T_{P W, \max }$ to the maximum values of the ranges from Eq. 13, Eq. 14 must be implemented:

$$
\boldsymbol{T}_{\boldsymbol{P W}, \boldsymbol{m a x}} \leq 100^{\circ} \mathrm{C} \cdot \boldsymbol{b}_{D, \mathbf{1 9 0 0}}+155^{\circ} \mathrm{C} \cdot \boldsymbol{b}_{D, 3250}+190^{\circ} \mathrm{C} \cdot \boldsymbol{b}_{D, 3850}
$$

For the North German Basin and the South German Molasse Basin, the temperature linear depends on the drilling depth (cf. section 3.2). In addition, equations are needed to ensure that the GTP has to be built $\left(b_{G P}=1\right)$ if a power plant $\left(b_{P P}=1\right)$ or DHP is built and to limit the nominal power of ORC and DH plant, $P_{e l, m a x}$ and $\dot{Q}_{t h, \max }$, to zero if not. The operating life of the plant is assumed to be 30 years based on Budisulistyo et al. (2017).

\subsection{Economic assessment}

In GTP projects, four main phases occur to which costs can be allocated. The four phases are resource identification, resource exploration, drilling and energy production (Clauser \& Ewert 2018). The costs for GTPs are subject to uncertainties. As an extreme example, investments in the Sauerlach project have 
increased from the original estimate of $25 \mathrm{M} €$ to $90 \mathrm{M} €$ (cf. Table A2, Zeitungsverlag tz 2014). The costfunctions in this section are mainly based on Schlagermann (2014). Three of the eight components of the investment in Table 3 that are particularly relevant for this study are explained in this section. An explanation of the remaining cost functions can be found in section A4.

Table 3: Components of the investment for the GTP and their dependence on variables of the GTP model.

\begin{tabular}{|c|c|c|}
\hline Variable of the component & Description of component & Depending on the following variables \\
\hline$C_{1}$ & Feasibilitystudy and preliminaryplanning & $\mathrm{b}_{\mathrm{GP}}, \mathrm{z}_{\mathrm{D}}$ \\
\hline $\mathrm{C}_{2}$ & Properties and infrastructure & $\mathrm{b}_{\mathrm{GP}}, \mathrm{b}_{\mathrm{PP}}, \mathrm{b}_{\mathrm{DHP}}, \mathrm{P}_{\mathrm{el}, \mathrm{max}}, \dot{\mathrm{Q}}_{\mathrm{th}, \max }$ \\
\hline$C_{3}$ & Exploration of the reservoir & $\mathrm{b}_{\mathrm{GP}}, \mathrm{b}_{\mathrm{W}, 1}, \mathrm{~b}_{\mathrm{W}, 2, \mathrm{ZD}_{\mathrm{D}}}$ \\
\hline$C_{4}$ & Production well pump & $\mathrm{b}_{\mathrm{W}, 1}, \mathrm{P}_{\mathrm{el}}, \dot{\mathrm{Q}}_{\mathrm{th}}$ \\
\hline$C_{5}$ & Thermal water system (above-ground) & $\mathrm{b}_{\mathrm{GP}}$ \\
\hline$C_{6}$ & Powergeneration plant & $P_{\text {el, } \max ,} b_{P P}$ \\
\hline$C_{7}$ & District heating system & $\mathrm{b}_{\mathrm{DH}, \mathrm{S}, \mathrm{i}}$ \\
\hline$C_{8}$ & $\begin{array}{l}\text { Project management, control and finance } \\
\text { planning as well as other investments }\end{array}$ & All variables from $\mathrm{C}_{1}-\mathrm{C}_{7}$ \\
\hline
\end{tabular}

The costs $C_{1}$ are divided into the costs for the feasibility study $C_{F S}$, the preliminary underground planning Cup as well as the preliminary planning of the power generation plant and the above-ground plant components $C_{P P}($ Schlagermann 2014):

$$
\begin{gathered}
\boldsymbol{C}_{\mathbf{1}}=\boldsymbol{C}_{\boldsymbol{F} \boldsymbol{S}}+\boldsymbol{C}_{\boldsymbol{U P}}+\boldsymbol{C}_{\boldsymbol{P P}}=\left(180,000 € \cdot \boldsymbol{b}_{\boldsymbol{G P}}\right)+\left(100,000 € \cdot \boldsymbol{b}_{\boldsymbol{G P}}+25,000 € / \mathrm{km}^{2} \cdot \boldsymbol{A}_{\boldsymbol{S}}\right)+\left(150,000 € \cdot \boldsymbol{b}_{\boldsymbol{G P}}\right) \\
\quad \text { with } \quad \boldsymbol{A}_{\boldsymbol{S}}=\left(\boldsymbol{z}_{\boldsymbol{D}}+4 \mathrm{~km}+d_{D}\right) \cdot\left(\mathbf{z}_{\boldsymbol{D}}+4 \mathrm{~km}\right)=\mathbf{z}_{\boldsymbol{D}}^{2}+9,5 \mathrm{~km} \cdot \boldsymbol{z}_{\boldsymbol{D}}+22 \mathrm{~km}^{2}
\end{gathered}
$$

The preliminary underground planning includes a 3D seismology for which the area As must be known. The vertical depth of the drillings $Z_{D}$ and the distance between the two drillings $d_{D}$ is required to calculate As. For $d D$, deflections of the drillings are also taken into account. According to Stober \& Bucher (2014), the distance in the underground, in the area of the working horizon, is usually $1,000-2,000 \mathrm{~m}$. Therefore $d_{D}$ is assumed to be 1,500 $\mathrm{m}$ in the following. In order to use Eq. 15 in the linear optimisation problem, the function must be linearised. This was achieved by dividing the function into five sections in 1,000 $\mathrm{m}$ steps. Now the costs can be calculated using the linearised cost functions (cf. Equations in red boxes in Figure 5).

The costs for the exploration of the reservoir $C_{3}$ are divided into costs for drilling $C_{D}$, stimulation $C_{S T}$, hydraulic tests $C_{H T}$ and geochemical investigations $C_{G I}$ (Schlagermann 2014). With a share of up to $70 \%$ of the capital costs, drilling costs account for the largest share of the investment for a GTP (Leipziger Institut für Energie 2007). The drilling costs are estimated according to the following equation (Eyerer et al. 2017):

$$
\boldsymbol{C}_{\boldsymbol{D}}=610,000 € * \boldsymbol{b}_{G P}+1.015 \cdot \boldsymbol{C}_{\boldsymbol{D} W}=610,000 € * \boldsymbol{b}_{\boldsymbol{G P}}+1.015 *\left[1.198 \cdot e^{0.00047894 \cdot \sqrt{z_{D}^{2}+d_{D}^{2}}} \cdot 10^{6} €\right]
$$

The term in the square brackets covers the costs of the actual drilling work $C_{D W}$, the rest is for the construction and recultivation of the well site, among other things. This study assumes that all drilling is done at one well site. Therefore, the costs of $610,000 €$ are only charged for the first well.

The drilling costs are assumed to be subject to economies of scale and the costs of the second well is only $90 \%$ of the costs of the first well. The same applies to the hydraulic tests with $67 \%$ as well as the geochemical investigations of the wells with $70 \%$ for the second well. The costs for the exploration of the reservoir can therefore be calculated using the following equations (Schlagermann 2014):

$$
\begin{aligned}
C_{3} & =C_{D}+C_{S T}+C_{H T}+C_{G I} \\
\text { with } \quad C_{D} & =610,000 € \cdot b_{G P}+1.015 \cdot C_{D W} \cdot(1+0.9) \\
C_{S T} & =450,000 € \cdot(1+0.67) \cdot \boldsymbol{b}_{G P}
\end{aligned}
$$




$$
\begin{aligned}
& \boldsymbol{C}_{\boldsymbol{H} T}=500,000 € \cdot \boldsymbol{b}_{\boldsymbol{G P}} \\
& \boldsymbol{C}_{\boldsymbol{G I}}=65 \frac{€}{\mathrm{~m}} \cdot \sqrt{\mathbf{z}_{\boldsymbol{D}}^{2}+d_{D}^{2}} \cdot(1+0.7)
\end{aligned}
$$

The investment for exploration of the reservoir $C_{3}$ thus depend on the vertical drilling depth according to the function in Figure 5. The deviations of the linearised curves from the actual costs $C_{1}$ and $C_{3}$ are between $-2 \%$ and $+1 \%$.

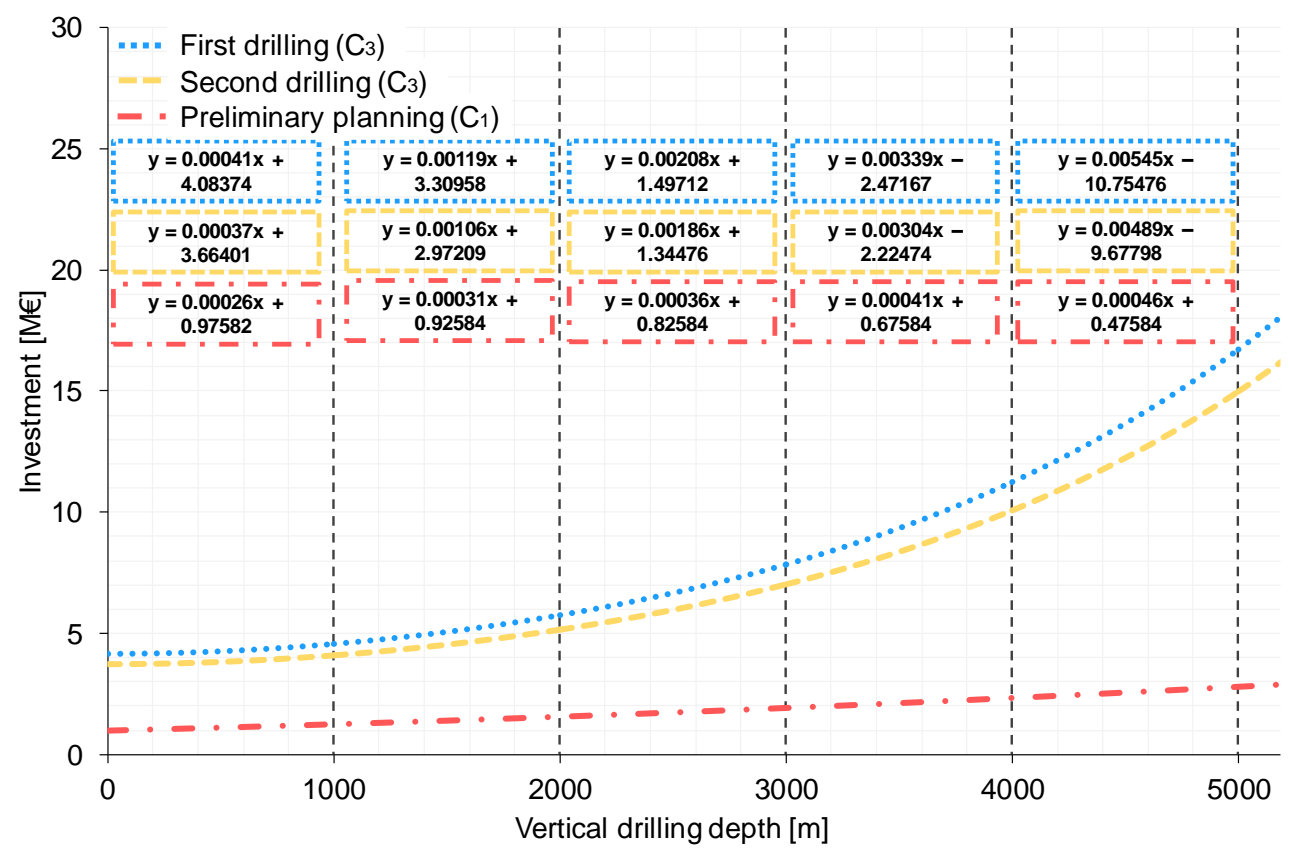

Figure 5: The costs for the feasibility study and the preliminary planning $C_{1}(r e d)$ and the costs for exploration of the reservoir $\mathrm{C}_{3}$ as a function of vertical drilling depth as well as linearization of the functions. The costs $\mathrm{C}_{3}$ are shown for the first (blue) and second (yellow) drilling. For a better analysis of the colours in this figure, please refer to the online version of the paper.

\subsection{Integration in $\mathrm{RE}^{3} \mathrm{ASON}$}

The entire GTP model presented above is integrated in the optimisation model of the RE ${ }^{3}$ ASON model, as explained in the following using the three model extensions.

1) Determination of the hydrothermal potential in a municipality (cf. section 3.2)

The achievable hydrothermal temperature serves as input for the optimisation model and is determined within the scope of the input calculation. The basin is also transferred to the model in order to determine the required drilling depth.

2) GTP model equations for simultaneous heat and electricity generation (cf. section 3.3) and

3) GTP cost determination (cf. section 3.4)

The technical and economic model equations are integrated into the $\mathrm{RE}^{3} \mathrm{ASON}$ optimisation model. The total costs for the GTP are determined as the sum of all individual costs $C_{1}$ to $C_{8}$. These total costs and the variable costs of the GTP are part of the objective function to calculate the total discounted system costs for the entire energy system (cf. Eqs. A.1-A.2 in the Appendix of McKenna et al. (2018)).

At this point it is necessary to clarify the consideration of the construction of a new DHN for the utilisation of the geothermal heat. The spatial resolution of the model is that of the district as a node (cf. 3.1). The costs for the DHN are calculated in several percentage steps of heat supply based on the heuristic developed in Weinand et al. (2019a). In the following a segmentation into ten steps is chosen, i.e. costs for the supply of $10 \%, 20 \%, 30 \%$ etc. up to $100 \%$ of the municipal heat demand. This also includes determining which buildings should optimally be connected to the DHN in the various steps. Therefore, 
the investigated municipality has to be divided into districts to also take account of energy flows in the optimisation process. For this purpose, a Voronoi clustering is performed on the basis of the settlements in the municipality. The resulting Voronoi cluster for an example municipality can be found in the electronic Appendix. For a given number of points in a plane, a Voronoi diagram divides the plane according to the rule of the nearest neighbour: each point is associated to the region closest to it (Aurenhammer 1991). The resulting districts are used to determine which settlements will be connected to the geothermal-based DHN. The investment for the DHN in the different steps serves as input for the optimisation model in $\mathrm{RE}^{3} \mathrm{ASON}$. In the optimisation model, the $\mathrm{DH}$ connections and costs then depend on the choice of the binary variable bDH,S,i (cf. Eq. 23).

$$
\sum_{i=1}^{10} \boldsymbol{b}_{D H, S, i} \leq 1
$$

For example, if all buildings/settlements in a municipality should be supplied with $\mathrm{DH}$, then $b_{D H},{ }_{10}$ has to be set to 1 . If only $70 \%$ of the heat demand should be covered by $\mathrm{DH}$, then $b_{D H, S, 7}=1$ applies. The DHN that results in this latter case can be found in the electronic Appendix for an example municipality. By selecting the binary variables, the output $\dot{Q}_{t h}$ of the $\mathrm{DH}$ plant is limited by a proportion of the heat demand of the municipality $D_{\text {neat,total }}$ (cf. Eq. 24).

$$
\dot{\boldsymbol{Q}}_{\boldsymbol{t h}}(\boldsymbol{t}) \leq \sum_{i=1}^{9}\left(\boldsymbol{b}_{\boldsymbol{D H}, \boldsymbol{S}, \boldsymbol{i}} \cdot 10 \% \cdot i \cdot D_{\text {heat }, \text { total }}(t)\right)+\left(\boldsymbol{b}_{\boldsymbol{D H}, \boldsymbol{S}, \mathbf{1 0}} \cdot M\right)
$$

The case with $100 \%$ is not included in the sum so that more $\mathrm{DH}$ can be generated than required. Therefore, the binary variable is multiplied by a large number $M$. In addition, the investment for the district heating system $C_{7}$ for the $\mathrm{DHN}$ can be specified with the binary variable $b_{D H}, S, i$.

\section{Results}

First, the GTP model is validated in section 4.1. Subsequently, in section 4.2, general information on the energy system optimisations are given and the results are presented in detail.

\subsection{Validation}

Validations are performed for the achievable hydrothermal temperatures and associated drilling depths as well as for the costcalculations (investment and LCOE). Table A2 shows a list of 31 deep geothermal projects in Germany, with corresponding data. The findings of this section can be analysed in more detail by examining the columns Temperature deviation, Temperature gradient and Depth deviation of Table A2 as well as the figures A1-A3. Since the drilling depths as well as the achieved temperatures are indicated in the projects, the model can be validated with the data from Table A2. For this purpose, the temperatures in the model are calculated on the basis of the actual drilling depths of the projects. The locations show deviations from the real achievable temperatures in the existing geothermal projects. The deviation could occur due to the fact that locations with above-average temperature gradients have been chosen for the geothermal projects realised so far. Furthermore, the hydrothermal temperatures could only be transferred as point coordinates of an $8.5 \mathrm{~km}^{2}$ grid. The root-mean-squared-error (RMSE) between the real and calculated temperature values is $27^{\circ} \mathrm{C}$. Actually, the RMSE calculated with the model equations would be only $16^{\circ} \mathrm{C}$, however, the calculated temperatures are limited by the maximum achievable temperatures from Figure 2. At 17 of the 31 locations, the deviations are less than 15\%, all deviations are on average 19\%. Apart from a few municipalities in the North German Basin, the accuracy of the model is considered sufficient for generic application and identification of municipalities with potential geothermal exploitation. For a detailed planning of a GTP plant, specific measurements have to be performed. Since hydrothermal temperature and drilling depth are directly interdependent in the model, the deviations are the same for both parameters. The validation of the investment for the GTP 
can be found in section A4.1 of the Appendix. All in all, the validation shows satisfactory results for the model. Due to the lack of data, however, it is not possible to predict the exact hydrothermal temperature and temperature gradient at a specific location. As already mentioned in the objectives in section 1, the applied methods are sufficient to estimate the geothermal potential for the energy system optimisations, since this study is intended to demonstrate possible utilisation of this potential.
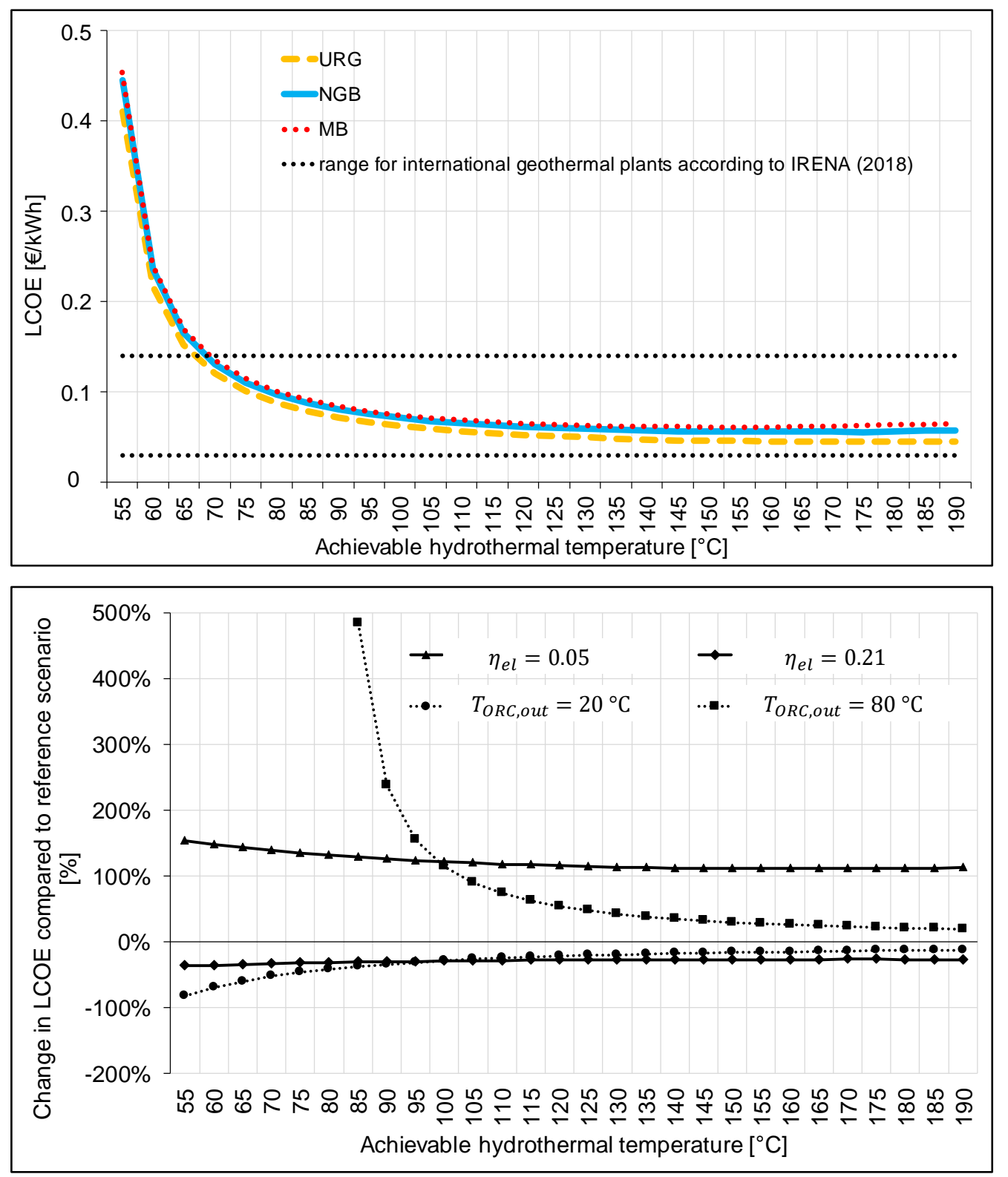

Figure 6: LCOE of geothermal power plants calculated by the model presented in this study using different achievable temperatures for the three large basins in Germany (upper part). The dotted black horizontal lines mark the area in which the $L C O E$ of real deep geothermal projects fall according to IRENA (2018). As a sensitivity analysis, the change in LCOE for the NGB are shown with parameter values deviating from the reference case (lower part). For a better analysis of the colours in this figure, please refer to the online version of the paper.

Figure 6 shows the calculated LCOE for geothermal power plants using the model equations developed

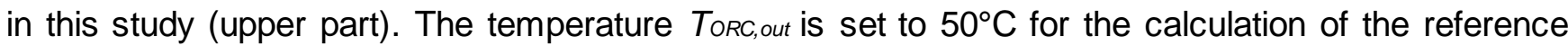
cases. Based on the achievable temperature, the LCOE are given for all three large basins in Germany. Values between $0.05 € / \mathrm{kWh}$ and $0.5 € / \mathrm{kWh}$ are reached. In 2017 the LCOE of selected international geothermal projects ranged between $0.03 € / \mathrm{kWh}$ and $0.14 € / \mathrm{kWh}$ (cf. area between black dotted lines in Figure 6, IRENA 2018). The range is given in general, not depending on the hydrothermal temperature. Since only projects with achievable temperatures of over $80^{\circ} \mathrm{C}$ are usually realised, the model can be assessed as plausible in this respect. For the NGB, four scenarios with changed 
parameter values compared to the reference case are also shown as sensitivities in the lower part of Figure 6. If the ORC efficiency $\eta_{e l}$ is reduced or TORC, out is increased, the LCOE increase. Thereby the deviation of the LCOE in comparison to the reference case decreases the higher the achievable hydrothermal temperature is. Furthermore, the deviation for parameter changes that reduce electricity production $\left(\eta_{e l}=5 \%\right.$ and TORC, out $\left.=80^{\circ} \mathrm{C}\right)$ is higher due to the high fixed costs of GTP. Since the LCOE deviation is largest in the scenario with an efficiency of $5 \%$ (in the relevant temperature range above $100{ }^{\circ} \mathrm{C}$ ), this sensitivity is also investigated in the optimisations in section 4.2.2. A validation of the $\mathrm{RE}^{3} \mathrm{ASON}$ model can be found in Mainzer (2019).

\subsection{Results of the energy system optimisation case studies}

Three German municipalities are selected as case studies. These municipalities are taken from three different municipality clusters (Weinand et al. 2019b), so that they differ considerably in terms of relevant indicators. The indicators of the municipalities important for the analyses are listed in Table 4. Westheim is selected to examine a densely populated municipality in the URG in which the maximum hydrothermal temperature of $190{ }^{\circ} \mathrm{C}$ can be reached. The case of Prinzenmoor, on the other hand, should show how the energy system changes, if a sparsely populated municipality is investigated. Furthermore, Groß Kreutz is chosen to investigate whether geothermal plants are also installed in municipalities with a large population and widely dispersed settlements in various districts as well as low hydrothermal potential.

Table 4: Characteristics of the municipalities Westheim, Prinzenmoor and Groß Kreutz examined in this study.

\begin{tabular}{|l|l|l|l|}
\hline Municipality & Westheim (Pfalz) & Prinzenmoor & Groß Kreutz (Havel) \\
\hline Cluster (Weinand et al. 2019b) & 3 & 4 & 8 \\
\hline Basin (Agemar et al. 2014) & URG & NGB & NGB \\
\hline Area [km ${ }^{2}$ ] & 7 & 6 & 99 \\
\hline Population & 1,731 & 179 & 8,133 \\
\hline Population density in municipality [1/km $\left.{ }^{2}\right]$ & 243 & 32 & 82 \\
\hline Number of districts & 1 & 1 & 12 \\
\hline Maximum hydrothermal temperature $\left[{ }^{[} \mathbf{C}\right]$ & 190 & 175 & 80 \\
\hline
\end{tabular}

The objective value of the optimisations are the total discounted system costs (TDSC). The energy systems are optimised for the period between 2015 and 2030. In addition, the majority of the optimisations consider complete municipal energy autonomy (CMEA), i.e. the demand must be met by local regenerative energy and no energy imports are allowed. In all optimisations, the MIP-Gap, the relative tolerance on the gap between the best integer objective and the objective of the best node remaining, is set to $5 \%$. The maximum capacity for the electricity storage per district is given as $20 \mathrm{MWh}$. Optimisation times depend largely on the number of districts in a municipality, as more energy flows need to be optimised in cases with many districts. In addition, the optimisations for Westheim lasted longer than for Prinzenmoor since Westheim is located in the Upper Rhine Graben and therefore Eqs. 13-14 become relevant. The calculation times ranged from a few hours to seven days. More information about the optimisation problem and the computation is given in Table 5. The number of variables and equations depends on the number of districts, therefore the optimisation problem for Groß-Kreutz is considerably larger. In addition, more equations and variables are contained for Westheim than for Prinzenmoor, due to the different modelling of the drilling depth (cf. Eq. 13). 
Table 5: Structure of the optimisation problem as well as properties and hardware for solving the model.

\begin{tabular}{|l|r|r|r|}
\hline Case study & Westheim (Pfalz) & Prinzenmoor & Groß Kreutz (Havel) \\
\hline Number of variables & 602,619 & 573,177 & $5,945,481$ \\
\hline Number of binary variables & 3,235 & 3,180 & 6,724 \\
\hline Number of equations & $1,074,006$ & $1,031,469$ & $8,484,842$ \\
\hline Programming language & General Algebraic Modeling System (GAMS) \\
\hline Solver & CPLEX (branch \& cut) \\
\hline Hardware properties & Intel Xeon E-1650 v2; 3.5 GHz; 12 Threads; 128 GB RAM \\
\hline
\end{tabular}

Further input data, including energy carrier price developments and techno-economic assumptions, can be found in the electronic Appendix.

Whilst scenario specifications and the optimisation results concerning the geothermal plant can be found in Table 6, the resulting TDSC and their development are shown in Figure 7. Before presenting specific results in detail in sections 4.2.1 and 4.2.2, the following list gives an overview of the most important results, as well as in which section and by which scenarios these results can be explained:

- Achieving CMEA is associated with a significant increase in TDSC and is never achieved unless it is enforced (all scenarios).

- The construction of a GTP is not worthwhile, if CMEA does not have to be achieved (W1, P1, GK1 in sections 4.2.1 - 4.2.2).

- The construction and operation of a GTP can significantly reduce the TDSC, if CMEA has to be achieved (W2 and GK2 in comparison with W5 and GK3 in section 4.2.1).

- The previous statement also applies to the case with significantly lower ORC efficiency (W3 in section 4.2.2).

- Neglecting the district heating option of a GTP by only considering the ORC could lead to higher TDSC (W2 in comparison with W4 in section 4.2.2).

- In municipalities with low population, the installation of a GTP is not worthwhile due to high fixed costs (P2 in comparison with P3 in section 4.2.2).

- In contrast, the TDSC can be significantly reduced, even at low hydrothermal potential, if the fixed costs of the GTP are distributed over a large population (GK2 in comparison with GK3 in section 4.2.2).

In the description of the results, the focus is on the GTP and electricity.

\subsubsection{Impact of geothermal plants on complete municipal energy autonomy}

Scenario W2 demonstrates on the one hand the importance of a GTP in achieving CMEA and on the other hand the importance of considering the heat side and the electricity side of the GTP. In comparison to scenario W5, in which the installation of a GTP is prohibited (cf. Table 6), the use of the GTP saves $1.6 \mathrm{k} €$ per inhabitant for the energy supply system until 2030 (cf. Figure 7). Thus, the use of a GTP can significantly reduce the cost of achieving CMEA. In scenario W2, only one biomass plant with a capacity of $225 \mathrm{~kW}$ el is built in addition to the GTP to cover the demand. Due to the base-load operation of the 1.1 $\mathrm{MW}_{\text {el }}$ ORC plant, the electricity demand is exceeded in some time steps (cf. Figure 8). In these cases, the excess energy is temporarily stored in a 1.3 MWh battery storage and reused as required. Scenario W5, on the other hand, requires an 18.2 MWh storage capacity in order to achieve CMEA using biomass and the volatile energy supply technologies PV and wind. This clarifies the high increase of the costs for CMEA through the use of large storage capacities which was already found in the literature in section 2.1. By the use of the GTP in scenario W2, these costs can be lowered, however, the TDSC increase by $70 \%$ in comparison to the reference scenario $\mathrm{W} 1$ without CMEA. 
Table 6: Scenarios including specifications as well as the results for the geothermal plant in the individual scenarios.

\begin{tabular}{|c|c|c|c|c|c|c|c|c|c|}
\hline \multirow[t]{2}{*}{ Scenario } & \multicolumn{4}{|c|}{ Scenario specifications } & \multicolumn{5}{|c|}{ GTP results } \\
\hline & $\begin{array}{l}\text { CMEA } \\
\text { forced? }\end{array}$ & $\begin{array}{l}\text { ORC } \\
\text { allowed? }\end{array}$ & $\begin{array}{l}\text { DH } \\
\text { allowed? }\end{array}$ & $\begin{array}{l}\text { Special } \\
\text { characteristics }\end{array}$ & $\begin{array}{l}\text { Drilling } \\
\text { depth [m] }\end{array}$ & $\begin{array}{l}\text { Tempera- } \\
\text { ture }\left[{ }^{\circ} \mathrm{C}\right]\end{array}$ & $\begin{array}{l}\text { ORC capac- } \\
\text { ity [kW] }\end{array}$ & $\begin{array}{l}\text { DH capac- } \\
\text { ity }[\mathrm{kW}]\end{array}$ & $\begin{array}{l}\text { GTP invest- } \\
\text { ment [M€] }\end{array}$ \\
\hline Westheim 1 (W1) & $x$ & $\checkmark$ & $\checkmark$ & & - & - & - & - & - \\
\hline Westheim 2 (W2) & $\checkmark$ & $\checkmark$ & $\checkmark$ & & 1,850 & 98 & 1,100 & 1,970 & 22 \\
\hline Westheim 3 (W3) & $\checkmark$ & $\checkmark$ & $\checkmark$ & $5 \%$ ORC efficiency & 2,130 & 109 & 610 & 1,920 & 22 \\
\hline Westheim 4 (W4) & $\checkmark$ & $\checkmark$ & $x$ & ORC forced & 1,580 & 85 & 1,390 & - & 18 \\
\hline Westheim 5 (W5) & $\checkmark$ & $x$ & $x$ & & - & - & - & - & - \\
\hline Prinzenmoor $1(\mathrm{P} 1)$ & $x$ & $\checkmark$ & $\checkmark$ & & - & - & - & - & - \\
\hline Prinzenmoor 2 (P2) & $\checkmark$ & $\checkmark$ & $\checkmark$ & & - & - & - & - & - \\
\hline Prinzenmoor 3 (P3) & $\checkmark$ & $\checkmark$ & $\checkmark$ & ORC forced & 1,590 & 56 & 230 & - & 15 \\
\hline Groß Kreutz 1 (GK1) & $x$ & $\checkmark$ & $\checkmark$ & & - & - & - & - & - \\
\hline Groß Kreutz 2 (GK2) & $\checkmark$ & $\checkmark$ & $\checkmark$ & & 2,290 & 80 & 1,200 & - & 20 \\
\hline Groß Kreutz 3 (GK3) & $\checkmark$ & $x$ & $x$ & & - & - & - & - & - \\
\hline
\end{tabular}

Since almost all heat demand is covered by the GTP via DH in scenario W2, only a few power-operated heat generators (e.g. electric storage heaters) are operated. The electric storage heaters are only needed for peak loads, which cannot be covered by the $\mathrm{DH}$ base load. A large part of the municipal power consumption is caused by the pump in the production well of the GTP. For further information on the distribution of the consumption patterns, please refer to the electronic Appendix.

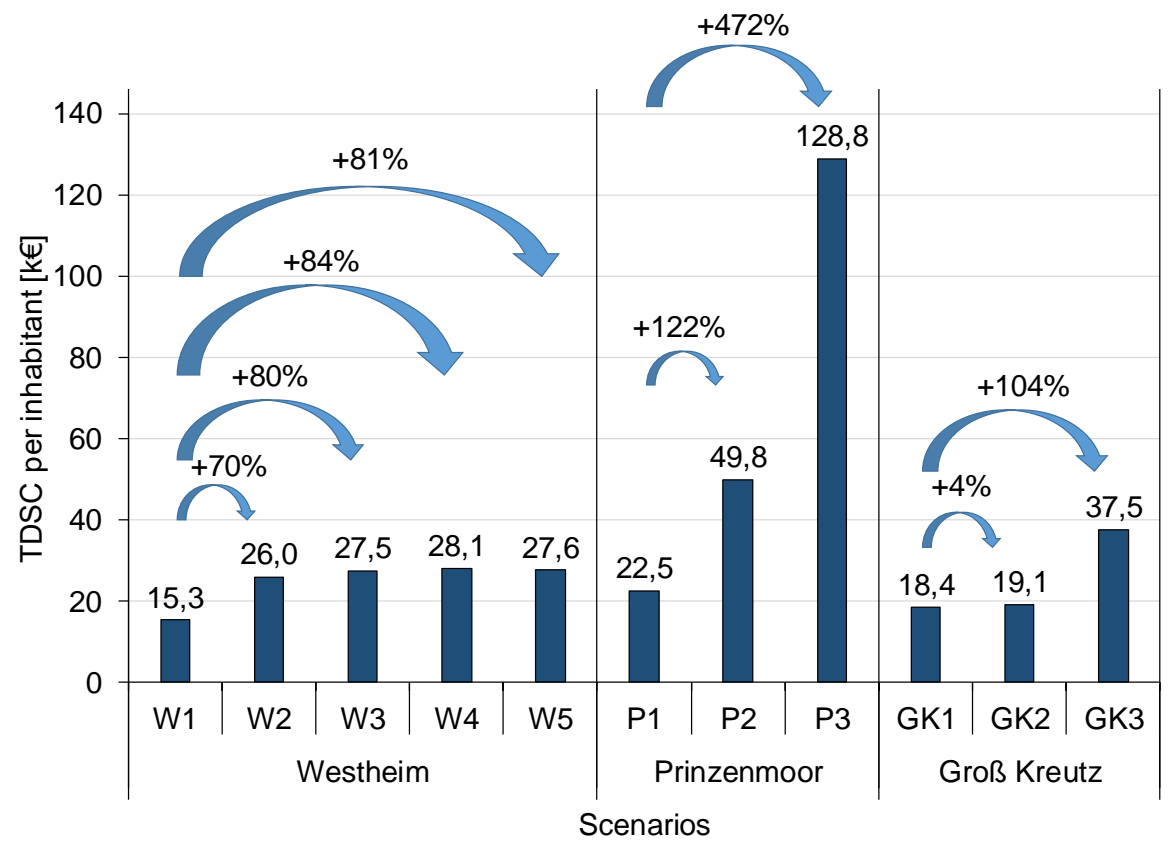

Figure 7: TDSC per inhabitant for the energy supply between 2015 and 2030 in various scenarios for the municipalities Westheim, Prinzenmoor and Groß Kreutz.

The preference for biomass plants and the GTP in scenario W2 over the volatile energy from wind and PV can be explained by the base load capability of the plants. However, it is not so obvious why the GTP is preferred instead of biomass plants, which can be operated flexibly in addition to the base load. On the one hand this is due to the low technical biomass potential in Westheim. On the other hand, the average LCOE of the potential biomass plants of $0.25 € / \mathrm{kWh}$ is significantly higher than that of the GTP amounting to (at least) $0.07 € / \mathrm{kWh}$ with a hydrothermal temperature of $98^{\circ} \mathrm{C}$. Even with assumptions that would reduce the performance of the GTP, the LCOE would still be below $0.25 € / \mathrm{kWh}$ (cf. section 4.1). 

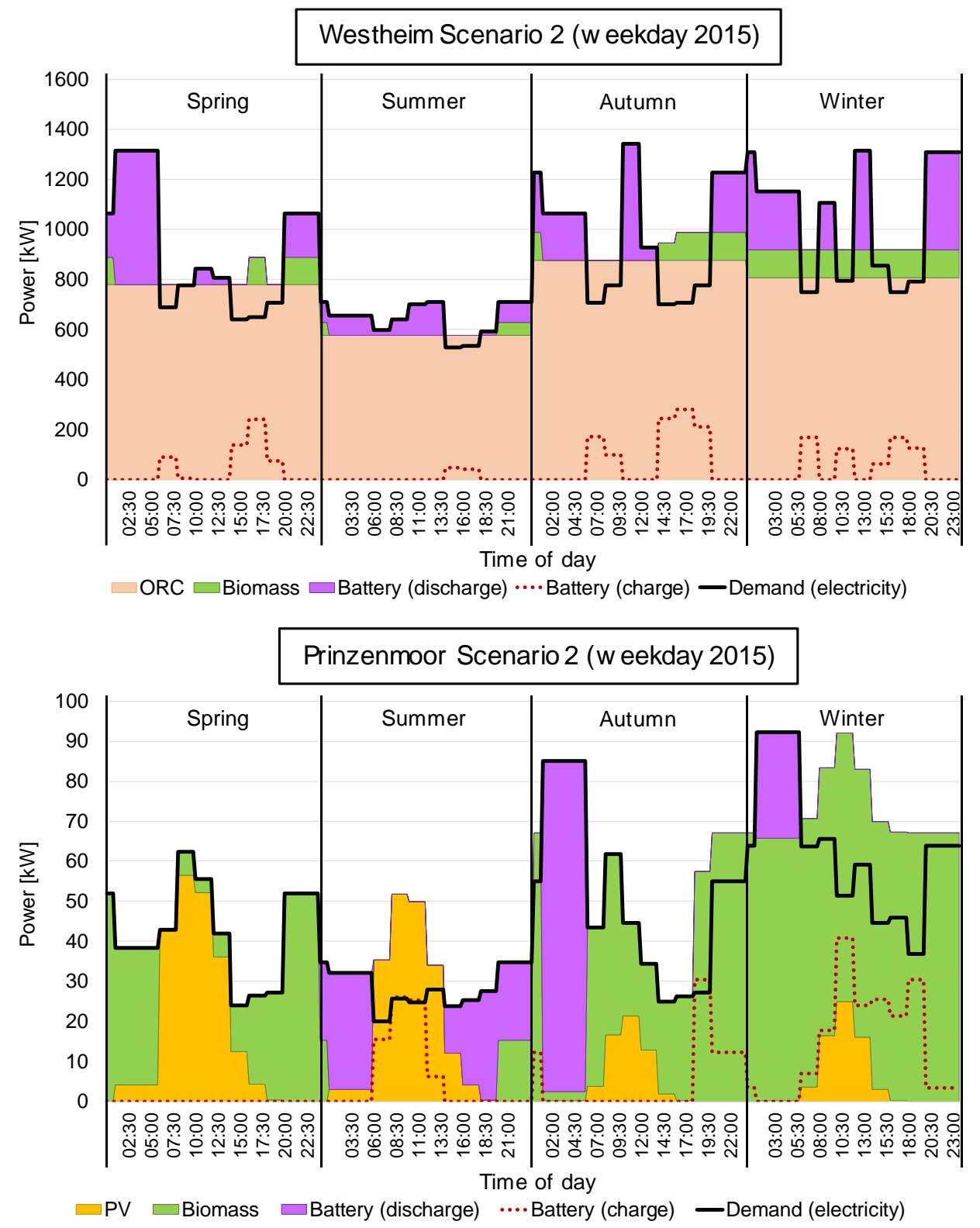

Figure 8: Optimised energy supply patterns (upperpart) - divided into energy supply technologies - on a typical weekday for all seasons in 2015 for the municipalities of Westheim (upper part) and Prinzenmoor (lower part). For a better analysis of the colours in this figure, please refer to the online version of the paper.

\subsubsection{Sensitivity analysis}

A particularly critical assumption in the modelling of the GTP in section 3.3 is the assumption of a constant ORC efficiency of $13 \%$. For this reason, scenario W2 is changed in scenario W3 in such a way that the efficiency is only $5 \%$. As shown in Table 6 , even in this case, an ORC plant and a DH system are built. The $1.5 \mathrm{k} €$ higher TDSC per inhabitant result primarily from the larger biomass plant and battery storage. An ORC plant is therefore constructed even with very low efficiency. The TDSC with the real efficiency would most likely be between the TDSC of scenarios W2 and W3.

The literature review in section 2.2 shows that GTPs are usually investigated with regard to electricity generation and not with regard to simultaneous electricity and heat generation. The results of scenario W4 demonstrate that simultaneous electricity and heat optimisation could create added value. The TDSC in scenario W4, in which no DH system may be installed, are $2.1 \mathrm{k} €$ higher per inhabitant than in scenario W2 (cf. Figure 7). The ORC system in scenario W4 has a higher capacity than in scenario W2, since more of the generated electricity has to be used for heat supply with heat pumps and electric storage heaters. Furthermore, the different drilling depths and the resulting hydrothermal 
temperatures in scenarios W2, W3 and W4 show the added value which results from the novel modelling of the drilling depth as a variable.

For the municipality Prinzenmoor, the costs in the scenarios with CMEA show a significant increase compared to the reference scenario P1 without CMEA (cf. Figure 7). This indicates that the small rural municipalities which are mainly examined in the literature are not necessarily more suitable for achieving CMEA than larger municipalities (cf. section 2.1), as will be clarified further below using scenario P3.

As Table 6 shows, no GTP is built to achieve CMEA in scenario P2. The energy demand is covered by PV rooftop modules, biomass plants and a battery storage. The largest peak loads, which are mainly caused by heat pumps, are covered by biomass and the battery (cf. Figure 8 ). If the construction of a GTP is forced (scenario P3), the TDSC increase by $472 \%$ compared to the reference scenario P1. This is due to the high fixed costs of the GTP, whose investment is not much lower than in the other scenarios despite significantly lower capacity (cf. Table 6). The two drillings alone account for $10 \mathrm{M} €$, corresponding to $66 \%$ of the total investment, which is distributed among significantly fewer inhabitants than in Westheim. This demonstrates that in smaller municipalities the fixed costs of the energy plants in particular lead to high TDSC per inhabitant. Therefore, economies of scale lead to lower TDSC in larger municipalities. Furthermore, the disadvantage of the lower temperature gradient in the NGB is evident, since the depth of the drillings in the URG would have to be only $970 \mathrm{~m}$ in order to reach the $56^{\circ} \mathrm{C}$, instead of $1,590 \mathrm{~m}$ in the NGB.

The dependence of the TDSC per inhabitant on the number of inhabitants is further confirmed in Groß Kreutz. Since the costs of the GTP are distributed among significantly more inhabitants than in the other two municipalities, CMEA only leads to a $4 \%$ increase in costs in scenario GK2 compared to reference scenario GK1. The increase in TDSC per inhabitant is significantly lower than in Prinzenmoor and Westheim (cf. Figure 7). Thus, in the case of CMEA, the construction of a geothermal plant is worthwhile even with a low hydrothermal potential. However, the construction of a $\mathrm{DH}$ plant is probably prevented by the low achievable temperature. A comparison of scenario GK2 with scenario GK3, in which no GTP may be installed, shows this again. The cost to achieve CMEA without GTP almost doubles in GK3 (cf. Figure 7). In GK3, wind turbines, PV modules, biomass plants and battery storages are installed.

\section{Critical appraisal}

This study is not without weaknesses which should be addressed in future work. While the developed model provides transferability to any German municipality ${ }^{4}$, the geological conditions on site must always be considered when planning a GTP. As shown in the previous sections, the model cannot guarantee $100 \%$ accuracy in the calculation of achievable hydrothermal temperatures, drilling depths and associated costs. This probably results from the average temperature gradients assumed for the different basins. The geothermal projects with which the model was compared were probably realised at sites with exceptionally high temperature gradients.

In addition, GTPs are sensitive to various types of scaling, including carbonate minerals, amorphous silicates, metal oxides and sulphides. Silica ( $\mathrm{SiO} 2)$, and calcite (CaCO3) are the most common. One result of the scaling is the degradation of plant components, which requires their premature replacement (Gunnlaugsson et al. 2014). In addition, the scaling reduces the diameter of the pipes and thus increases the total pressure drop and the friction factor in the pipe (Zarrouk et al. 2014). In the water of lowtemperature GTPs $\left(T<150{ }^{\circ} \mathrm{C}\right.$ at $1 \mathrm{~km}$ depth) there is no silica saturation even when cooling to approximately $20^{\circ} \mathrm{C}$ in DH systems (Gunnlaugsson et al. 2014). This would therefore be applicable to all locations in Germany. Problems caused by the high salt content in the water of the North German 
Basin are avoided by the relatively high injection temperature of at least $50{ }^{\circ} \mathrm{C}$, which is applied in this study (Magri et al. 2009).

Furthermore, some assumptions about parameters like constant efficiencies, temperatures and flow rates were necessary to represent the GTP in a linear optimisation model. The temperature dependent ORC efficiency is one of the most critical assumptions and has been investigated in the sensitivity analysis (cf. section 4.2.2). The ORC efficiency did not have a significant impact: although the TDSC have increased while the efficiency was considerably lower (+7\%), the GTP has been built nevertheless to achieve CMEA. For the other parameters, the assumptions are rather conservative, but the impacts should also be further examined in the future. Due to the employed assumptions, the statement that a simultaneous optimisation of heat and electricity of the geothermal plant is recommended has to be critically evaluated. The fact that the installation and operation of the district heating system in scenarios W2 and W3 leads to lower TDSC could be explained by the uncertainties of the model. On the other hand, the efficiency of the competing ORC plant is overestimated. Since the district heating option is applied nevertheless, district heating should also be considered in future modelling of geothermal plants.

In addition, the GTP is assumed to operate without outages. This leads to a moderate underestimation of the LCOE of the GTP. A possible improvement of this weakness could be to create redundancy, which still allows the operation of the plant in the case of a pump outage. To this end, the model could be extended by the option to build a triplet instead of a doublet (Baasch 2011), which consists of an injection well and two production wells (Majorowicz \& Grasby 2010). The heat from the reservoir could be used for up to ten years longer with a triplet well layout in comparison to a doublet well layout due to improved system performance (Jiang et al. 2014).

Another important issue for future studies is the investigation of the influence of the time series structure on the results. In the $\mathrm{RE}^{3} \mathrm{ASON}$ model an hourly resolution is used. A higher resolution would involve higher peak loads, which could make CMEA no longer achievable in municipalities, or with greater effort. Furthermore, only extreme days were considered in this study. In future analyses longer extreme periods could be considered to take periods of very low solar and wind production into account. However, even with only one extreme day per season, geothermal plants were built in the cases considered in this study.

Furthermore, the fact already mentioned in the literature was confirmed: the total costs to achieve CMEA increase very much, if large battery storage capacities are required (cf. section 4.2.2). Besides battery storages for short-term purposes, it would also be sensible to include seasonal storages, such as hydrogen storages, in upcoming analyses.

Finally, the choice of the system boundaries must also be considered. The analysis of the municipality of Prinzenmoor showed that CMEA in small municipalities is associated with high additional costs due to the high fixed costs of the energy supply technologies. These municipalities could therefore be analysed together with smaller neighbouring municipalities. Since the municipality Groß Kreutz with the least TDSC in a CMEA scenario is the largest of the investigated municipalities with regard to the population, the conclusion is obvious that there could be an optimal municipality scale for CMEA. All of the aspects mentioned in this section will be the focus of forthcoming contributions.

\section{Conclusions}

The objective of this paper is the investigation of the economic feasibility of complete municipal energy autonomy in an energy system including geothermal plants. Therefore, a generic optimisation model of a geothermal plant, which simultaneously generates electricity and heat, is developed and integrated into an existing holistic energy system optimisation model. Variable drilling depths and thus hydrothermal temperatures represent one of the novel modelling approaches. As input for the optimisation, a linear regression estimates the achievable hydrothermal temperatures and the required 
drilling depths in the municipalities. Some cost estimations for the geothermal plant, such as drilling costs, had to be linearised for this purpose. A validation of the cost and the input determination with data from actual plants shows that the model presented in this work can reasonably be applied to any municipality in Germany without additional efforts ${ }^{4}$.

Related to the above objective, the specific research questions addressed in this paper are as follows. Could the high costs for off-grid municipal energy systems be reduced through the use of geothermal plants? Is it sufficient to consider only the electricity generation of the geothermal plant or would the use of the geothermal heat in district heating networks create an additional benefit? In order to answer these questions, the developed optimisation model was applied to three different municipalities from different municipal clusters. Eleven scenarios demonstrated that achieving energy autonomy is associated with high additional costs. Compared to the scenarios without energy autonomy, total discounted system costs for the period between 2015 and 2030 have increased by at least 4\%. Thereby, the utilisation of geothermal plants can significantly reduce the costs for achieving energy autonomy, which answers the first research question above. The electricity generation is preferred to heat generation in geothermal plants, which is related to the high costs for the district heating network. However, the importance of simultaneous modelling of electricity and heat generation in geothermal plants is evident, as district heating plants reduce the costs, especially in municipalities with high hydrothermal potential. This provides an answer to the second research question, i.e. that in the context of municipal energy system planning it is not sufficient to only consider the electricity side of the plant. Therefore, the installation of geothermal plants could help to decarbonise the energy system through energy autonomy.

This paper has developed a generally-applicable method for the optimal setup of a GTP within or near a residential area and considering both heat and electricity generation. Together with the related contribution for optimally locating the GTP plant within an existing or new district heating network (Weinand et al. 2019a), the consideration of the heat side represents a significant step forward. Compared to previous studies that focussed on a detailed GTP system setup, typically optimised for power generation, the present paper adopts a more holistic approach. The current and the above cited paper together provide a methodological framework for the economically effective and energetically efficient integration of GTPs into local energy systems. In the context of renewable energy system planning this therefore represents an invaluable tool in the context of the energy transition. Furthermore, the employed method is intended to be highly transferable, both within Germany and, by employing additional data sources, beyond. It can provide decision support to local energy planners and other relevant stakeholders when considering the renewable energy options at their disposal.

Due to the fact that the employed methodology is intended as an early-stage planning tool, it has several uncertainties, however. Hence the authors emphasize the need for a more detailed energy system planning, especially but not only relating to the GTP, before entering the implementation phase. Most importantly, the costs of geothermal plants are very uncertain and depend on local geological conditions. Whilst the model presented provides a good estimate of the hydrothermal temperatures, the investment can rise due to uncertain incidents. Further work should also include the investigation of the impact of a higher temporal resolution as well as the identification of the optimal spatial scale for energy autonomy.

\section{Acknowledgement}

The authors gratefully acknowledge funding by the German Federal Ministry of Education and Research (BMBF) within the Kopernikus Project ENSURE 'New ENergy grid StructURes for the German Energiewende' (funding reference: FKZ 03SFK1N0) as well as the financial support of the PhD College "Energy and Resource Efficiency" (ENRES), from the Federal State of Baden-Wuerttemberg, for funding the first author's PhD studentship. The contribution of the second author (RM) was supported by the Heat 4.0 project from the Danish Innovation Fund (Reference 8090-00046B). The contribution of the third author (MK) was supported by the Helmholtz Association under the Joint initiative "Energy Systems 
Integration" (funding reference: ZT-0002). The authors also thank five anonymous reviewers and the editor, who provided valuable comments on earlier versions of this manuscript. The usual disclaimer applies.

\section{References}

Aali, A.; Pourmahmoud, N.; Zare, V. (2017): Exergoeconomic analys is and multi-objective optimization of a novel combined flash-binary cycle for Sabalan geothermal power plant in Iran. In Energy Conversion and Management 143, pp. 377-390. DOI: 10.1016/j.enconman.2017.04.025.

Agemar, Thorsten; Schellschmidt, Rüdiger; Schulz, Rüdiger (2012): Subsurface temperature distribution in Germany. In Geothermics 44, pp.65-77. DOI: 10.1016/j.geothermics.2012.07.002.

Agemar, Thorsten; Weber, Josef; Schulz, Rüdiger (2014): Deep Geothermal Energy Production in Germany. In Energies 7 (7), pp. 4397-4416. DOI: 10.3390/en7074397.

Agemar, T.; Weber, J.; Moeck, I. (2018): Assessment and Public Reporting of Geothermal Resources in Germany. Review and Outlook. In Energies 11 (2), p. 332. DOI: 10.3390/en11020332.

Astolfi, Marco; Romano, Matteo C.; Bombarda, Paola; Macchi, Ennio (2014): Binary ORC (organic Rankine cycles) power plants for the exploitation of medium-low temperature geothermal sources - Part A. Thermodynamic optimization. In Energy 66, pp. 423-434. DOI: 10.1016/j.energy.2013.11.056.

Alt, B. (2017): Norddeuts che Gemeinde stellt komplett auf erneuerbare Energien um (Northern German community switches completely to renewable energies). Available online at http://www.sonnens eite.com/de/energie/norddeutsche-gemeinde-stelltkomplett-auf-erneuerbare-energien-um.html, checked on 5/9/2018.

Aurenhammer, Franz (1991): Voronoi diagrams---a survey of a fundamental geometric data structure. In ACM Comput. Surv. 23 (3), pp. 345-405. DOI: 10.1145/116873.116880.

Baasch, R. (2011): Pullach schlägt neues Kapitel in der Geothermiegeschichte a uf (Pullach opens new chapter in geothermal history). In Geothermische Energie 1 (70), pp. 10-11.

Balcombe, Paul; Rigby, Dan; Azapagic, Adisa (2015): Energy self-sufficiency, grid demand variability and consumer costs. Integrating solar PV, Stirling engine CHP and battery storage. In Applied Energy 155, pp. 393-408. DOI: 10.1016/j.apenergy.2015.06.017.

Bauer, Mathias; Freeden, Willi; Jacobi, Hans; Neu, Thomas (2014): Handbuch Tiefe Geothermie. Prospektion, Exploration, Realisierung, Nutzung (Handbook Deep Geothermal Energy. Prospecting, Exploration, Realization, Use). Berlin, Heidelberg: Springer Spektrum (SpringerLink Bücher). Available online at http://dx.doi.org/10.1007/978-3-642-54511-5.

Bertani, Ruggero (2016): Geothermal power generation in the world 2010-2014 update report. In Geothermics 60, pp. 31-43. DOI: 10.1016/j.geothermics.2015.11.003.

BMWi (2017): Erneuerbare Energien in Zahlen. Nationale und internationale Entwicklung im Jahr 2016 (Renewable energies in figures. National and international development in 2016). Available online at https://www.bmwi.de/Redaktion/DE/Publikationen/Energie/erneuerbare-energien-in-zahlen-

2016.pdf?_blob=publicationFile\&v=8, checked on 5/9/2018.

Boon, Frank Pieter; Dieperink, Carel (2014): Local civil society based renewable energy organisations in the Netherlands. Exploring the factors that stimulate their emergence and development. In Energy Policy 69, pp. 297-307. DOI: 10.1016/j.enpol.2014.01.046.

Budisulistyo, Denny; Wong, Choon Seng; Krumdieck, Susan (2017): Lifetime design strategy for binary geothermal plants considering degradation of geothermal resource productivity. In Energy Conversion and Management 132, pp. 1-13. DOI: 10.1016/j.enconman.2016.10.027.

Bundesverband Geothermie (2013): Neue Projektliste: Tiefe Geothermie schreitet voran (New project list: Deep geothemal energy is progressing). Available online at http://www.geothermie.de/news-anzeigen/2013/07/02/neue-projektliste-tiefegeothermie-schreitet-voran.html, checked on 3/20/2018.

Bundesverband Geothermie (2018): Tiefe Geothermieprojekte in Deutschland (Deep geothermal projects in Germany). Available online at http://www.geothermie.de/fileadmin/useruploads/wissenswelt/Projektliste_Tiefe_Geothermie_2018.pdf, checked on $3 / 20 / 2018$

Burgess, Paul J.; Rivas Casado, Monica; Gavu, Jerry; Mead, Andrew; Cockerill, Tim; Lord, Richard; van der Horst, Dan; Howard, David C. (2012): A framework for reviewing the trade-offs between, renewable energy, food, feed and wood production at a local level. In Renewable and Sustainable Energy Reviews 16 (1), pp. 129-142. DOI: 10.1016/j.rser.2011.07.142.

Campos Rodríguez, Carlos Eymel; Escobar Palacio, José Carlos; Venturini, Osvaldo J.; Silva Lora, Electo E.; Cobas, Vladimir Melián; Marques dos Santos, Daniel; Lofrano Dotto, Fábian R.; Gialluca, V. (2013): Exergetic and economic comparison of ORC and Kalina cycle for low temperature enhanced geothermal system in Brazil. In Applied Thermal Engineering 52 (1), pp. 109-119. DOI: 10.1016/j.applthermaleng.2012.11.012.

Chagnon-Lessard, Noémie; Mathieu-Potvin, François; Gosselin, Louis (2016): Geothermal power plants with maximized specific power output. Optimal working fluid and operating conditions of subcritical and transcritical Organic Rankine Cycles . In Geothermics 64,pp. 111-124. DOI: 10.1016/j.geothermics.2016.04.002.

Clarke, Joshua; McLay, Laura; McLeskey, James T. (2014): Comparis on of genetic algorithm to particle swarm for constrained simulation-based optimization of a geothermal power plant. In Advanced Engineering Inform atics 28 (1), pp. 81-90. DOI: 10.1016/j.aei.2013.12.003. 
Clarke, Joshua; McLeskey, James T. (2015): Multi-objective particle swarm optimization of binary geothermal power plants. In Applied Energy 138, pp. 302-314. DOI: 10.1016/j.apenergy.2014.10.072.

Clauser, Christoph; Ewert, Markus (2018): The renewables cost challenge. Levelized cost of geothermal electric energy compared to other sources of primary energy - Review and case study. In Renewable and Sustainable Energy Reviews 82 , pp. 3683-3693. DOI: 10.1016/j.rser.2017.10.095.

Elmegaard, Brian; Ommen, Torben Schmidt; Markussen, Michael; Iversen, Johnny (2016): Integration of space heating and hot water supply in low temperature district heating. In Energy and Buildings 124, pp. 255-264. DOI: 10.1016/j.enbuild.2015.09.003.

Enerchange (2009): Sauberes Jubiläum: 15 Jahre Geothermie in Neustadt-Glewe (Clean anniversary: 15 years of geothermal energy in Neustadt-Glewe). Available online at http://www.tiefegeothermie.de/top-themen/sauberes-jubilaeum-15-jahregeothermie-in-neustadt-glewe, checked on 3/20/2018.

Enerchange (2018): Projekte Tiefe Geothermie (Projects Deep Geothermal Energy). Available online at http://www.tiefegeothermie.de/projekte, checked on 3/20/2018.

Engelken, Maximilian; Römer, Benedikt; Drescher, Marcus; Welpe, Isabell (2016): Transforming the energy system. Why municipalities strive for energy self-sufficiency. In Energy Policy 98, pp. 365-377. DOI: 10.1016/j.enpol.2016.07.049.

Engelken, Maximilian; Römer, Benedikt; Drescher, Marcus; Welpe, Isabell (2018): Why homeowners strive for energy selfsupplyand how policy makers can influence them. In Energy Policy 117, pp. 423-433. DOI: 10.1016/j.enpol.2018.02.026.

Erdwärme Grünwald GmbH (2013): Erdwärme Grünwald: „Hinter dem Mehr an Kosten steckt ein Mehr an Leistung.“ (Geothermal energy Grünwald: "There is more power behind the extra costs."). Available online at http://www.erdwaermegruenwald.de/_URL/E1086.htm, checked on 3/20/2018.

Eyerer, Sebastian; Schifflechner, Christopher; Hofbauer, Sebastian; Wieland, Christoph; Zosseder, Kai; Bauer, Wolfgang Baumann, Thomas; Heberle, Florian; Hackl, Chris toph; Irl, Matthäus; Spliethoff, Hartmut (2017): Potential der hydrothermalen Geothermie zur Stromerzeugung in Deutschland (Potential of hydrothermal geothermal energy for power generation in Germany). Bayerisches Staatsministerium für Bildung und Kultus, Wissenschaft und Kunst. Available online at https://www.es.mw.tum.de/fileadmin/w00bhq/www/pdf/Potential_der_hydrothermalen_Geothermie_zur_Stromerzeugung_in_ Deutschland.pdf, checked on 10/2/2017.

Frey, M.; Milles, U. (2007): Geothermische Stromerzeugung in Landau (Geothermal power generation in Landau). Edited by FIZ Karlsruhe. Available online at http://www.bine.info/fileadmin/content/Publikationen/Projekt-Infos/2007/Projekt-Info_142007/projekt_1407internet-x.pdf, checked on 1/16/2018.

Geothermie Unterhaching (2017): Datenblatt: Geothermie Unterhaching (Data sheet: Geothermal Unterhaching). Available online at https://www.geothermieunterhaching.de/cms/geothermie/web.nsf/gfx/0189A5952BAEB5E8C1258183003FA71A/\$file/Datenblatt\%20Geothermie\%20 Unterhaching\%202017.pdf, checked on 3/20/2018.

Ghaebi, Hadi; Namin, Amin Shekari; Rostamzadeh, Hadi (2018): Exergoeconomic optimization of a novel cascade Kalina/Kalina cycle using geothermal heat source and LNG cold energy recovery. In Journal of Cleaner Production. DOI: 10.1016/j.jclepro.2018.04.049.

Ghasemi, Hadi; Paci, Marco; Tizzanini, Alessio; Mitsos, Alexander (2013): Modeling and optimization of a binary geothermal power plant. In Energy 50, pp. 412-428. DOI: 10.1016/j.energy.2012.10.039.

Griva, Igor; Nash, Stephen G.; Sofer, Ariela (2009): Linear and nonlinear optimization. 2. ed. Philadelphia, PA: Society for Indus trial and Applied Mathematics (OT / SIAM, Society of Indus trial and Applied Mathematics, 108)

GTN (2012a): Geothermie Groß Schönebeck. Vorbereitung des Kommunikationsexperimentes und Einbindung der ORCAnlagen (Geothermal energy Groß Schönebeck. Preparation of the communication experiment and integration of the ORC systems). Edited by Geothermie Neubrandenburg GmbH. Available online at http://www.gtnonline.de/media/PDF/GTN_Tiefe_Geothermie_Kommunikationsexperiment_Gro\%C3\%9F_Schonebeck_052012.pdf, checked on 3/20/2018.

GTN (2012b): Geothermisches Heizwerk Neustadt-Glewe (Geothermal heating plant Neustadt-Glewe). Edited by Geothermie Neubrandenburg GmbH. Available online at http://www.gtnonline.de/media/PDF/GTN_Tiefe_Geothermie_Geothermisches_Heizwerk_Neustadt_Glewe_052012.pdf, checked on 3/20/2018.

Gunnlaugsson, E.; Ármannsson, H.; Thorhallsson, S.; Steingrimsson, B. (2014): Problems in Geothermal operaton - scaling and corrosion. Santa Tecla, El Salvador (Short Course VI on Utilization of Low-and Medium-Enthalpy Geothermal Resources and Financial). Available online at https ://orkustofnun.is/gogn/unu -gtp-sc/UNU-GTP-SC-18-19.pdf, checked on 3/9/2018.

Guzović, Z.; Majcen, B.; Cvetković, S. (2012): Possibilities of electricity generation in the Republic of Croatia from mediumtemperature geothermal sources. In Applied Energy 98, pp. 404-414. DOl: 10.1016/j.apenergy.2012.03.064.

Huster, Wolfgang R.; Bongartz, Dominik; Mitsos, Alexander (2017): Deterministic Global Optimization of the Design of a Geothermal Organic Rankine Cycle. In Energy Procedia 129, pp. 50-57. DOI: 10.1016/j.egypro.2017.09.181.

IRENA (2018): Renewable power generation costs in 2017. Edited by International Renewable Energy Ag ency. Abu Dhabi. Available online at

https://www.irena.org//media/Files/IRENA/Agency/Publication/2018/Jan/IRENA_2017_Power_Costs_2018.pdf, checked on 9/5/2018.

IWU (Ed.) (2015). Deutsche Wohngebäudetypologie. Beispielhafte Maßnahmen zur Verbesserung der Energieeffizienz von typischen Wohngebäuden (zweite erweiterte Auflage). (German domestic building typology. Exemplary measures to improve the energy efficiency of typical domestic buildings). With assistance of Tobias Loga, Britta Stein, Nikolaus Diefenbach, Rolf Born, IWU, Darmstadt, Accessed 21 January 2016. 
Jägemann, C., Hagspiel, S., Lindenberger, D. (2013): The economic inefficiency of grid parity: The case of German photovoltaics. EWI Working Paper No 13/19, December 2013.

Jain, Charitra; Vogt, Christian; Clauser, Christoph (2015): Maximum potential for geothermal power in Germany based on engineered geothermal systems. In Geotherm Energy 3 (1), p. 655. DOI: 10.1186/s40517-015-0033-5.

Jancik, S.; Kupfermann, G. A. (2014): Vorhaben Ilb. Stromerzeugung aus Geothermie (Project llb. Power generation from geothermal energy). Available online at https://www.clearingstelle-eeg-kwkg.de/files/zwischenbericht-vorhaben-2b.pdf, checked on 3/21/2018.

Jenssen, Till; König, Andreas; Eltrop, Ludger (2014): Bioenergy villages in Germany. Bringing a low carbon energy supply for rural areas into practice. In Renewable Energy61, pp. 74-80. DOI: 10.1016/j.renene.2012.08.014.

Jiang, Fangming; Chen, Jiliang; Huang, Wenbo; Luo, Liang (2014): A three-dimensional transient model for EGS subsurface thermo-hydraulic process. In Energy 72, pp. 300-310. DOI: 10.1016/j.energy.2014.05.038.

Karimi, Shahram; Mansouri, Sima (2018): A comparative profitability study of geoth ermal electricity production in developed and developing countries. Exergoeconomic analysis and optimization of different ORC configurations. In Renewable Energy 115, pp. 600-619. DOI: 10.1016/j.renene.2017.08.098.

Koirala, Binod Prasad; Koliou, Elta; Friege, Jonas; Hakvoort, Rudi A.; Herder, Paulien M. (2016): Energetic communities for community energy. A review of key issues and trends shaping integrated community energy systems. In Renewable and Sustainable Energy Reviews 56, pp. 722-744. DOI: 10.1016/j.rser.2015.11.080.

Kolahi, Mohammad-Reza; Nemati, Arash; Yari, Mortaza (2018): Performance optimization and improvement of a flash -binary geothermal power plant using zeotropic mixtures with PSO algorithm. In Geothermics 74, pp. 45-56. DOI: 10.1016/j.geothermics.2018.02.004.

KramI, M.; Walzer, M. (2008): Geothermie. Wertschöfpfung und Wirtschaftlichkeit von Geothermieprojekten in Deutschland (Geothermal energy. Value creation and profitability of geothermal projects in Germany). Edited by forseo $\mathrm{GmbH}$. Available online at http://www.endura-kom munal.de/uploads/media/Geothermie_in_Deutschland_18.pdf, checked on 4/10/2018.

Lazzarin, Nicolò; Zanellato, Luca; Frassinetti, Marco (2017): Cycle and turbine re-optimization on geothermal resources significantly deviating from the expected conditions. In Energy Procedia 129, pp.615-620. DOI: 10.1016/j.egypro.2017.09.219. Leipziger Institut für Energie (2007): Tiefe Geothermie in Deutschland (Deep geothermal energy in Germany). Edited by Bundesministerium für Umwelt, Naturschutz und Reaktorsicherheit. Available online at https://www.magsprojekt.de/MAGS/DE/Downloads/BMU_TiefeGeothermie.pdf?_blob=publicationFile\&v=1, checked on 1/18/2018.

Lindenberger, D.; Bruckner, T.; Groscurth, H.-M; Kümmel, R. (2000): Optimization of solar district heating systems. Seasonal storage, heat pumps, and cogeneration. In Energy 25 (7), pp. 591-608. DOI: 10.1016/S0360-5442(99)00082-1.

Liu, Q.; Shen, A.; Duan, Y. (2015): Parametric optimization and performance analyses of geothermal organic Rankine cycles using R600a/R601a mixtures as working fluids. In Applied Energy 148, pp. 410-420. DOI: 10.1016/j.apenergy.2015.03.093.

Liu, Q.; Shang, L.; Duan, Y. (2016): Performance analyses of a hybrid geothermal-fossil power generation system using lowenthalpy geothermal resources. In Applied Energy 162, pp. 149-162. DOI: 10.1016/j.apenergy.2015.10.078.

Liu, Xiaomin; Wei, Ming; Yang, Luona; Wang, Xing (2017): Thermo-economic analysis and optimization selection of ORC system configurations for low temperature binary-cycle geothermal plant. In Applied Thermal Engineering 125, pp. $153-164$. DOI: 10.1016/j.applthermaleng.2017.07.016.

Lu, X.; Zhao, Y.; Zhu, J.; Zhang, W. (2018): Optimization and applicability of compound power cycles for enhanced geothermal systems. In Applied Energy 229, pp. 128-141. DOI: 10.1016/j.apenergy.2018.07.033.

Magri, Fabien; Bayer, Ulf; Pekdeger, Asaf; Otto, Roland; Thomsen, Claudia; Maiwald, Ulrike (2009): Salty groundwater flow in the shallow and deep aquifer systems of the Schleswig-Holstein area (North German Basin). In Tectonophysics 470 (1-2), pp. 183-194. DOI: 10.1016/j.tecto.2008.04.019.

Mainzer, Kai; Killinger, Sven; McKenna, Russell; Fichtner, Wolf (2017): Assessment of rooftop photovoltaic potentials at the urban level using publicly available geodata and image recognition techniques. In Solar Energy 155, pp. 561-573. DOI: 10.1016/j.solener.2017.06.065.

Mainzer, K. (2019): Analyse und Optimierung urbaner Energiesysteme: Entwicklung und Anwendung eines übertragbaren Modellierungswerkzeugs zur nachhaltigen Systemgestaltung. (Analysis and optimisation of urban energy systems: development and application of a transferable modelling tool for sustainable system design). Dissertation. Karls ruhe Institute of Technology. Institute for Industrial Production (IIP), in press.

Majorowicz, Jacek; Grasby, Stephen E. (2010): High Potential Regions for Enhanced Geothermal Systems in Canada. In Natural Resources Research 19 (3), pp. 177-188. DOI: 10.1007/s11053-010-9119-8.

Makhanlall, Deodat;Zhang, Fuzhen; Xu, Ruina; Jiang, Peixue (2015): Exergy-topological analysis and optimization of a binary power plant utilizing medium-grade geothermal energy. In Applied Thermal Engineering 88, pp. 459-463. DOI: 10.1016/j.applthermaleng.2014.09.017.

Martínez-Gomez, Juan; Peña-Lamas, Javier; Martín, Mariano; Ponce-Ortega, José María (2017): A multi-objective optimization approach for the selection of working fluids of geothermal facilities. Economic, environmental and social aspects. In Journal of environmental management203 (Pt 3), pp. 962-972.DOI: 10.1016/j.jenvman.2017.07.001.

Marty, Fabien; Serra, Sylvain; Sochard, Sabine; Reneaume, Jean-Michel (2018): Simultaneous optimization of the District Heating Network topology and the Organic Rankine Cycle sizing of a geothermal plant. In Energy. DOI: 10.1016/j.energy.2018.05.110. 
McKenna, Russell; Herbes, Carsten; Fichtner, Wolf (2015): Energieautarkie. Vorschlag einer Arbeits definition als Grundlage für die Bewertung konkreter Projekte und Szenarien (Energy autonomy. Proposal of a working definition as a basis for the evaluation of concrete projects and scenarios). In Z Energiewirtsch 39 (4), pp. 235-252. DOI: 10.1007/s 12398-015-0164-1.

McKenna, Russell; Merkel, Erik; Fichtner, Wolf (2017): Energy au tonomy in residential buildings. A techno-economic modelbased analys is of the scale effects. In Applied Energy 189, pp. 800-815. DOI: 10.1016/j.apenergy.2016.03.062.

McKenna, R. (2018): The double-edged sword of decentralized energy autonomy. In Energy Policy 113, pp. 747-750. DOI: 10.1016/j.enpol.2017.11.033.

McKenna, R.; Bertsch, V.; Mainzer, K.; Fichtner, W. (2018): Combining local preferences with multi-criteria decision analysis and linear optimization to develop feasible energy concepts in small comm unities. In European Journal of Operational Research 268 (3), pp. 1092-1110. DOI: 10.1016/j.ejor.2018.01.036.

Mohammadzadeh Bina, Saeid; Jalilinasrabady, Saeid; Fujii, Hikari (2017): Thermo-economic evaluation of various bottoming ORCs for geothermal power plant, determination of optimum cycle for Sabalan power plant exhaust. In Geothermics 70, pp. 181-191. DOI: 10.1016/j.geothermics.2017.06.007.

Mohammadzadeh Bina, Saeid; Jalilinasrabady, Saeid; Fujii, Hikari (2018): Exergoeconomic analys is and optimizatio n of single and double flash cycles for Sabalan geothermal power plant. In Geothermics 72, pp. 74-82. DOI: 10.1016/j.geothermics.2017.10.013.

Mosaffa, A. H.; Mokarram, N. Hasani; Farshi, L. Garousi (2017): Thermo-economic analysis of combined different ORCs geothermal power plants and LNG cold energy. In Geothermics 65, pp. 113-125. DOI: 10.1016/j.geothermics.2016.09.004.

Müller, Matthias Otto; Stämpfli, Adrian; Dold, Ursula; Hammer, Thomas (2011): Energy autarky. A conceptual framework for sustainable regional development. In Energy Policy 39 (10), pp. 5800-5810. DOI: 10.1016/j.enpol.2011.04.019.

Mundaca, Luis; Busch, Henner; Schwer, Sophie (2018): 'Successful' low -carbon energytransitions at the communitylevel? An energy justice perspective. In Applied Energy 218, pp. 292-303. DOI: 10.1016/j.apenergy.2018.02.146.

Nakomcic-Smaragdakis, Branka; Dvornic, Tijana; Cepic, Zoran; Dragutinovic, Natasa (2016): Analysis and possible geothermal energy utilization in a municipality of Panonian Basin of Serbia. In Ren ewable and Sustainable Energy Reviews 59, pp. 940951. DOI: 10.1016/j.rser.2015.12.337.

OpenStreetMap contributors (2018): $\quad$ OpenStreetMap. Available online https ://www.openstreetmap.org/\#map=5/51.330/10.453, checked on 1/29/2018.

Østergaard, Poul Alberg; Mathiesen, Brian Vad; Möller, Bernd; Lund, Henrik (2010): A renewable energyscenario for Aalborg Municipality based on low-temperature geothermal heat, wind power and biomass. In Energy 35 (12), pp. 4892-4901. DOI: 10.1016/j.energy.2010.08.041.

Østergaard, Poul Alberg; Lund, Henrik (2011): Arenewable energysystem in Frederikshavn using low -temperature geothermal energy for district heating. In Applied Energy 88 (2), pp. 479-487. DOI: 10.1016/j.apenergy.2010.03.018.

OVB24 GmbH (2009): Geothermie: Startklar für Anfang September (Geothermal energy: Ready for the beginning of September). Available online at https://www.innsalzach24.de/innsalzach/region-waldkraiburg/geothermie-projektwaldkraiburg-startklar-anfang-september-is24-388190.html, checked on 3/20/2018.

Ozgener, Leyla; Ozgener, Onder (2009): Monitoring of energy exergy efficiencies and exergoeconomic parameters of geothermal district heating sys tems (GDHSs). In Applied Energy 86 (9), pp. 1704-1711. DOI: 10.1016/j.apenergy.2008.11.017.

Pambudi, Nugroho Agung; Itoi, Ryuichi; Jalilinasrabady, Saeid; Jaelani, Khasani (2014): Exergy analysis and optimization of Dieng single-flash geothermal power plant. In Energy Conversion and Management 78, pp. 405-411. DOI: 10.1016/j.enconman.2013.10.073.

Pambudi, Nugroho Agung; Itoi, Ryuichi; Jalilinasrabady, Saeid; Gürtürk, Mert (2018): Sustainability of geothermal power plant combined with thermodynamic and silica scaling model. In Geothermics 71, pp. 108-117. DOI: 10.1016/j.geothermics.2017.09.003.

Peña-Lamas, Javier; Martinez-Gomez, Juan; Martín, Mariano; María Ponce-Ortega, José (2018): Optimal production of power from mid-temperature geothermal sources. Scale and safety issues. In Energy Conversion and Management 165, pp. 172182. DOI: 10.1016/j.enconman.2018.03.048.

Peter, Stefan (2013): Modellierung einer vollständig auf erneuerbaren Energien basierenden Stromerzeugung im Jahr 2050 in autarken, dezentralen Strukturen (Modelling of electricity generation based entirely on renewable energies in 2050 in selfsufficient, decentralised structures). Edited by Umweltbundesamt.

Petrakopoulou, Fontina; Robinson, Alexander; Loizidou, Maria (2016): Simulation and evaluation of a hybrid concentratingsolar and wind power plant for energy autonomy on islands. In Renewable Energy 96, pp. 863-871. DOl: 10.1016/j.renene.2016.05.030.

Peura, Pekka; Haapanen, Ari; Reini, Kaarina; Törmä, Hannu (2018): Regional impacts of sustainable energ y in westem Finland. In Journal of Cleaner Production 187, pp. 85-97. DOI: 10.1016/j.jclepro.2018.03.194.

Pollet, Mathieu; Gosselin, Louis; Dallaire, Jonathan; Mathieu-Potvin, François (2018): Optimization of geothermal power plant design for evolving operating conditions. In Applied Thermal Engineering 134, pp. 118-129. DOI: 10.1016/j.applthermaleng.2018.01.030.

Purkus, Alexandra; Barth, Volker (2011): Geothermal power production in future electricity markets -A scenario analys is for Germany. In Energy Policy 39 (1), pp. 349-357. DOI: 10.1016/j.enpol.2010.10.003.

Quoilin, Sylvain; van den Broek, Martijn; Declaye, Sébastien; Dewallef, Pierre; Lemort, Vincent (2013): Techno -economic survey of Organic Rankine Cycle (ORC) systems. In Renewable and Sustainable Energy Reviews 22, pp. 168-186. DOI: 10.1016/j.rser.2013.01.028. 
Rohloff, K.; Kather, A. (2011): Geothermische Stromerzeugung. Kraftwerkstechnologien und Technologien zur gekoppelten Erzeugung von Strom und Wärme (Geothermal power generation. Power plant technologies and technologies for combined generation of electricity and heat). Edited by Bundesministerium für Umwelt, Naturschutz und Reaktorsicherheit. Available online at https://www.bgr.bund.de/MAGS/DE/Downloads/BMU_Strom.pdf?_blob=publicationFile\&v=1, checked on 4/10/2018.

Rubio-Maya, Carlos; Pastor Martínez, Edgar; Romero, Carlos E.; Ambriz Díaz, Víctor M.; Pacheco-lbarra, J. Jesús (2016): Techno-economic as sessment for the integration into a multi-product plant based on cascade utilization of geothermal energy. In Applied Thermal Engineering 108,pp. 84-92. DOI: 10.1016/j.applthermaleng.2016.07.108.

Schallenberg, K. (1996): Vergleich des energiekonzeptionellen Aufbaus von drei geothermischen Heizzentralen (Comparison of the energy conceptual structure of three geothermal heating plants). Edited by Geoforschungszentrum Potsdam (Geothermie-Report 96-1). Available online at

potsdam.de/pubman/item/escidoc:8432:7/component/escidoc:10033/9608.pdf, checked on 4/5/2018.

Scheffer, K. (2008): Vom Bioenergiedorf zur autonomen Solarenergieregion (From a bioenergyvillage to an autonomous solar energy region). In Solarzeitalter 20 (4), pp. 23-30, checked on 11/2/2017.

Schlagermann, Pascal (2014): Exergoökonomische Analyse geothermischer Strombereitstellung am Beispiel des Oberrheingrabens (Exergoeconomic analys is of geothermal power supply using the Upper Rhine Graben as an example). München: Dr. Hut.

Schmalwasser, O.; Brede, S. (2015): Grund und Boden als Bestandteil der volkswirtschaftl ichen Vermögensbilanzen (Land as a component of the economic balance sheets of assets). Edited by Statistisches Bundesamt (WISTA). Available online at https://www.destatis.de/DE/Publikationen/WirtschaftStatistik/2015/06/GrundBodenBestandteilVermoegensbilan zen_062015.p df? _ blob=publicationFile, checked on 4/16/2018.

Schmidt, J.; Schönhart, M.; Biberacher, M.; Guggenberger, T.; HausI, S.; Kalt, G.; Leduc, S.; Schardinger, I.; Schmid, E. (2012): Regional energyautarky. Potentials, costs and consequences for an Austrian region. In Energy Policy 47, pp. 211-221. DOI: 10.1016/j.enpol.2012.04.059.

Schröder, E.; Thomauske, K.; Schmalzbauer, J.; Herberger, S. (2015): Measuring Techniques for in Situ Measurements of Thermodynamic Properties of Geothermal Water. Melbourne, Australia (Proceedings World Geothermal Congress 2015). Available online at $h$ ttps://pangea.stanford.edu/ERE/db/WGC/papers/WGC/2015/15022.pdf, checked on 4/3/2018.

Shengjun, Z.; Huaixin, W.; Tao, G. (2011): Performance comparison and parametric optimization of subcritical Organic Rankine Cycle (ORC) and transcritical power cycle system for low-temperature geothermal power generation. In Applied Energy 88 (8), pp. 2740-2754. DOI: 10.1016/j.apenergy.2011.02.034.

Sigurdardottir, Silja R.; Valfells, Agust; Palsson, Halldor; Stefansson, Hlynur (2015): Mixed integer optimization model for utilizing a geothermal reservoir. In Geothermics 55, pp. 171-181. DOI: 10.1016/j.geothermics.2015.01.006.

Statistisches Bundesamt (2016a): Kauffälle, Veräußerte Fläche, Durchschnittlicher Kaufwert für Bauland:Deutschland, Jahre, Baulandarten, Gemeindegrößenklassen (Purchase cases, area sold, average purchase value for building land: Germany, years, building land types, municipal size classes). Available online at https://wwwgenesis.destatis.de/genesis/online/logon?language=de\&sequenz=tabelleErgebnis\&selectionname=61511 -0005 , checked on 3/15/2018.

Statistisches Bundesamt (2016b): Preise. Kaufwerte für Bauland (Prices. Purchase values for building land). Available online at https ://www.destatis .de/DE/Publikationen/Thematisch/Preise/Baupreise/KaufwerteBaulandVj2170500163234.pdf?_blob=pu blicationFile, checked on 3/15/2018.

Statistisches Bundesamt (2017a): Bruttostromerzeugung in Deutschland für 2015 bis 2017 (Gross electricity generation in Germany for 2015 to 2017). Available online https://www.destatis .de/DE/ZahlenFakten/Wirtschafts bereiche/Energie/Erzeugung/Tabellen/Bruttostromerzeugung.htm, checked on 5/9/2018.

Statistisches Bundesamt (2017b): Gemeindeverzeichnis - Gebietsstand:30.06.2017 (2. Quartal). Alle politisch selbständigen Gemeinden (mit Gemeindeverband) in Deutschland nach Fläche, Bevölkerung (auf Grundlage des Zensus 2011), Bevölkerungs dichte und der Postleitzahl des Verwaltungssitzes der Gem einde (Municipality directory - Area status: 30.06 .2017 (2nd quarter). All politically independent municipalities (with municipal association) in Germany by area, population (on the basis of the 2011 census), population density and the postcode of the administrative seat of the municipality). Edited by Statistische Ämter des Bundes und der Länder. Wiesbaden. Available online at https://www.destatis .de/DE/ZahlenFakten/LaenderRegionen/Regionales/Gemeindeverzeichnis/Administrativ/Archiv/GVAuszu gQ/AuszugGV2QAktuell.html, checked on 9/7/2017.

Stober, Ingrid; Bucher, Kurt (2014): Geothermische Nutzungsmöglichkeiten (Geothermal applications). In Ingrid Stober, Kurt Emil Bucher (Eds.): Geothermie. 2., überarb. u. aktualisierte Aufl. 2014. Berlin: Springer Spektrum, pp. 37-64.

Sun, Qingxuan; Wang, Yaxiong; Cheng, Ziyang; Wang, Jiangfeng; Zhao, Pan; Dai, Yiping (2017): Thermodynamic Optimization of a Double-pressure Organic Rankine Cycle Driven by Geothermal Heat Source. In Energy Procedia 129, pp. 591-598. DOI: 10.1016/j.egypro.2017.09.214.

Sun, Jie; Liu, Qiang; Duan, Yuanyuan (2018): Effects of evaporator pinch point temperature difference on thermo-economic performance of geothermal organic Rankine cycle systems. In Geothermics 75, pp. 249-258. DOI: 10.1016/j.geothermics.2018.06.001.

Sveinbjörnsson, Dadi; Ben Amer-Allam, Sara; Hansen, Anders Bavnhøj; Algren, Loui; Pedersen, Allan Schrøder (2017): Energy supplymodelling of a low-CO 2 emitting energy system. Case study of a Danish municipality. In Applied Energy 195, pp. 922-941. DOI: 10.1016/j.apenergy.2017.03.086. 
trend:research (2017): Eigentümerstruktur: Erneuerbare Energien. Entwicklung der Akteurs vielfalt, Rolle der Energievers orger, Ausblick bis 2020 (Ownership structure: Renewable energies. Diversity of actors, role of energy suppliers, outlook until 2020). Available online at https://www.trendresearch.de/studie.php?s=672, checked on 5/9/2018.

UBA (2018a): Erneuerbare Energien in Deutschland. Daten zur Entwicklung im Jahr 2017 (Renewable energies in Germany. Data on the development in 2017). Edited by Umweltbundesamt. Available online at https://www.umweltbundesamt.de/sites/default/files/medien/376/publikationen/180315_uba_hg_eeinzahlen_2018_bf.pdf, checked on 6/28/2018.

UBA (2018b): Stromerzeugung erneuerbar und konventionell (Renewable and conventional power generation). Edited by Umweltbundesamt. Available online at https://www.umweltbundesamt.de/daten/energie/stromerzeugung-erneuerbarkonventionell\#textpart-1, checked on 4/6/2018.

van Erdeweghe, Sarah;van Bael, Johan; Laenen, Ben; D'haeseleer, William (2018): Optimal combined heat-and-power plant for a low-temperature geothermal source. In Energy 150, pp. 396-409. DOI: 10.1016/j.energy.2018.01.136.

van Erdeweghe, S.; van Bael, J.; Laenen, B.; D`haeseleer, W. (2019): Design and off-design optimization procedure for lowtemperature geothermal organic Rankine cycles. In Applied Energy 242, pp. 716-731. DOI: 10.1016/j.apenergy.2019.03.142. Walraven, D.; Laenen, B.; D`haeseleer, W. (2015): Minimizing the levelized co st of electricity production from low-temperature geothermal heat sources with ORCs: Water or air cooled? In Applied Energy 142, pp. 144-153. DOI: 10.1016/j.apenergy.2014.12.078.

Weber, J.; Ganz, B.; Sanner, B.; Moeck, I. (2016): Geothermal Energy Use, Cou ntry Update for Germany. Strasbourg, France (European Geothermal Congress 2016). Available online at https://www.geothermalenergy.org/pdf/IGAstandard/EGC/2016/GERMANY\%20country\%20update\%20EGC\%202016.pdf, checked on 6/28/2018.

Wu, Chuang; Wang, Shun-sen; Jiang, Xihang; Li, Jun (2017): Thermodynamic analysis and performance optimization of transcritical power cycles using CO2 -based binary zeotropic mixtures as working fluids for geothermal power plants. In Applied Thermal Engineering 115, pp. 292-304. DOI: 10.1016/j.applthermaleng.2016.12.077.

Weinand, Jann Michael; Kleinebrahm, Max; McKenna, Russell; Mainzer, Kai; Fichtner, Wolf (2019a): Developing a combinatorial optimisation approach to design district heating networks based on deep geothermal energy. In Applied Energy 251, p. 113367. DOI: 10.1016/j.apenergy.2019.113367.

Weinand, Jann Michael; McKenna, Russell; Fichtner, Wolf (2019b): Developing a municipality typology for modelling decentralised energysystems. In Utilities Policy57, pp. 75-96. DOI: 10.1016/j.jup.2019.02.003.

Woyke, Wolfgang; Forero, Mario (2014): Methoden zur Bewertung regionaler Energieautarkie (Methods for assessing regional energy self-sufficiency). Beitrag auf dem 13. Symposium Energieinnovation. Graz, Österreich.

Yang, Min-Hsiung; Yeh, Rong-Hua (2015): Economic performances optimization of the transcritical Rankine cycle systems in geothermal application. In Energy Conversion and Management 95, pp. 20-31. DOI: 10.1016/j.enconman.2015.02.021.

Yilmaz, Ceyhun (2017): Thermoeconomic modeling and optimization of a hydrogen production system using geothemal energy. In Geothermics 65, pp. 32-43. DOI: 10.1016/j.geothermics.2016.08.008.

Zare, V. (2015): A comparative exergoeconomic analys is of different ORC configurations for binary geotherm al power plants. In Energy Conversion and Management 105, pp. 127-138. DOI: 10.1016/j.enconman.2015.07.073.

Zarrouk, Sadiq J.; Moon, Hyungsul (2014): Efficiency of geothermal power plants. A worldwide review. In Geothermics 51, pp. 142-153. DOI: 10.1016/j.geothermics.2013.11.001.

Zarrouk, Sadiq J.; Woodhurst, Blair C.; Morris, Chris (2014): Silica scaling in geothermal heat exchangers and its impact on pressure drop and performance. Wairakei binary plant, New Zealand. In Geothermics 51, pp. 445-459. DOI: 10.1016/j.geothermics.2014.03.005.

Zeitungsverlag tz (2014): Erdwärme-Projekt: Viel zu teuer gebohrt (Geothermal energy project: drilled far too expensively). Edited by Zeitungsverlag tz München $\mathrm{GmbH} \& \mathrm{Co}$. KG. Available online at https://www.tz.de/muenchen/s tadt/erdwaemeprojekt-viel-teuer-gebohrt-tz-3701680.html, checked on 3/26/2018.

Zhao, Yajing; Wang, Jiangfeng (2016): Exergoeconomic analys is and optimization of a flash -binary geothermal power system. In Applied Energy 179, pp. 159-170. DOI: 10.1016/j.apenergy.2016.06.108. 


\section{Appendix}

\section{A1. Literature review table}

Table A1: Literature review on energy system analyses with geothermal plants.

\begin{tabular}{|c|c|c|c|c|c|c|c|}
\hline Study & Methodology & $\begin{array}{l}\text { Assessment } \\
\text { area/region or } \\
\text { plant site }\end{array}$ & Objective function & Energy system & Plant type & $\begin{array}{l}\text { Energy } \\
\text { Gener- } \\
\text { ation }\end{array}$ & $\begin{array}{l}\text { Brine } \\
\text { tempera- } \\
\text { ture }\end{array}$ \\
\hline Aali et al. (2017) & $\begin{array}{l}\text { Exergoeconomic analysis and multi- } \\
\text { objective optimisation }\end{array}$ & $\begin{array}{l}\text { Site: Sablan } \\
\text { geothermal } \\
\text { field (Iran) }\end{array}$ & Specific cost of output pow er and exergy efficiency & Geothermal plant & $\begin{array}{l}\text { Combined flash- } \\
\text { binary ORC }\end{array}$ & Power & $165-183$ \\
\hline Astolfiet al. (2014) & Optimisation & - & Thermodynamic efficiency & Geothermal plant & Binary ORC & Pow er & $120-180$ \\
\hline $\begin{array}{l}\text { Budisulistyo et al. } \\
\text { (2017) }\end{array}$ & Thermo-economic analysis & $\begin{array}{l}\text { Taupo } \\
\text { Volcanic Zone } \\
\text { (New Zealand) }\end{array}$ & Plant performance and lif etime & Geothermal plant & Binary ORC & Pow er & 131 \\
\hline $\begin{array}{l}\text { Chagnon-Lessard et } \\
\text { al. (2016) }\end{array}$ & $\begin{array}{l}\text { Thermodynamic numerical } \\
\text { simulation and optimisation }\end{array}$ & - & Specific pow er output & Geothermal plant & ORC & Pow er & $80-180$ \\
\hline Clarke et al. (2014) & $\begin{array}{l}\text { Comparison of genetic algorithm w ith } \\
\text { particle sw arm optimisation for the } \\
\text { constrained, non-linear, simulation- } \\
\text { based optimisation }\end{array}$ & - & Plant performance (power output) & Geothermal plant & Double flash & Pow er & - \\
\hline $\begin{array}{l}\text { Clarke \& McLeskey } \\
(2015)\end{array}$ & $\begin{array}{l}\text { Multi-objective particle sw arm } \\
\text { optimisation (MOPSO) }\end{array}$ & - & $\begin{array}{l}\text { Pareto-optimal set of designs depending on brine } \\
\text { temperature and dry-bulb temperature }\end{array}$ & Geothermal plant & Binary ORC & Pow er & $80-180$ \\
\hline Ghaebi et al. (2018) & $\begin{array}{l}\text { Exergoeconomic analysis \& single- } \\
\text { and multi-objective optimisations } \\
\text { (using genetic algorithm (GA)) }\end{array}$ & - & $\begin{array}{l}\text { Total levelized cost of energy system products; } \\
\text { thermal efficiency along with the exergy efficiency. }\end{array}$ & Geothermal plant & $\begin{array}{l}\text { Cascade } \\
\text { cycle }(\mathrm{CKC})\end{array}$ & Heat & 170 \\
\hline $\begin{array}{l}\text { Ghasemi et al. } \\
(2013)\end{array}$ & Parametric optimisation & - & Net pow er output & Geothermal plant & Binary ORC & Pow er & 135 \\
\hline Guzović et al. (2012) & $\begin{array}{l}\text { Optimisation of the main parameters } \\
\text { of ORC and Kalina cycle. }\end{array}$ & $\begin{array}{l}\text { Lunjkovec- } \\
\text { Kutnajk, } \\
\text { Croatia }\end{array}$ & $\begin{array}{l}\text { Power output, by optimising the main cycle } \\
\text { parameters: } \\
\text { ORC: upper cycle pressure } \\
\text { Kalina: concentration of ammonia } \\
\end{array}$ & Geothermal plant & $\begin{array}{l}\text { ORC and Kalina } \\
\text { cycle }\end{array}$ & Pow er & 140 \\
\hline Huster et al. (2017) & $\begin{array}{l}\text { Deterministic global optimisation of } \\
\text { component size and operating } \\
\text { conditions (Non Linear Program) }\end{array}$ & - & Net pow er; LCOE & Geothermal plant & ORC & Pow er & 135.85 \\
\hline $\begin{array}{l}\text { Karimi \& Mansouri } \\
\text { (2018) }\end{array}$ & $\begin{array}{llr}\text { Exergoeconomic } & \text { analysis } & \text { and } \\
\text { optimisation of different } & \text { ORC } \\
\text { configurations } & & \end{array}$ & $\begin{array}{l}20 \text { countries } \\
\text { (e.g. Australia, } \\
\text { Brazil, Jordan) }\end{array}$ & $\begin{array}{l}\text { Exergy efficiency, specific investment cost (SIC) and } \\
\text { a combination of exergy and SIC }\end{array}$ & Geothermal plant & $\begin{array}{l}\begin{array}{l}\text { Organic } \\
\text { Cycle }\end{array} \text { (Onkine } \\
\text { Regenerative } \\
\text { Rankine } \\
\text { (RORC) and Two- } \\
\text { Stage Evaporation } \\
\text { Organic Rankine } \\
\text { Cycle (TSEORC) }\end{array}$ & Pow er & $\begin{array}{l}61.85 \\
211.85\end{array}$ \\
\hline
\end{tabular}




\begin{tabular}{|c|c|c|c|c|c|c|c|}
\hline Study & Methodology & $\begin{array}{l}\text { Assessment } \\
\text { area/region or } \\
\text { plant site }\end{array}$ & Objective function & Energysystem & Plant type & $\begin{array}{l}\text { Energy } \\
\text { Gener- } \\
\text { ation }\end{array}$ & $\begin{array}{l}\text { Brine } \\
\text { tempera- } \\
\text { ture }\end{array}$ \\
\hline Kolahi et al. (2018) & Particle sw armoptimisation & $\begin{array}{l}\text { Sabalan } \\
\text { geothermal } \\
\text { pow er plant } \\
\text { (Iran) }\end{array}$ & Maximum total output pow er & Geothermal plant & Flash-binary ORC & Power & $31-188$ \\
\hline $\begin{array}{l}\text { Lazzarin et al. } \\
\text { (2017) }\end{array}$ & $\begin{array}{l}\text { Cycle and turbine re-optimisation on } \\
\text { geothermal resources }\end{array}$ & - & Net electrical output & Geothermal plant & - & Pow er & 145 \\
\hline Liu et al. (2015) & $\begin{array}{l}\text { Parametric optimisation } \quad \text { and } \\
\text { performance analysis }\end{array}$ & - & Net pow er output & Geothermal plant & ORC & Pow er & $110-150$ \\
\hline Liu et al. (2016) & $\begin{array}{l}\text { Analysis of the thermodynamic } \\
\text { performance of a hybrid geothermal- } \\
\text { fossil pow er generation system for } \\
\text { various geothermal resource } \\
\text { temperatures }\end{array}$ & - & - & Plant & $\begin{array}{l}\text { Hybrid } \\
\text { fossil geothermal- } \\
\text { generation system }\end{array}$ & Pow er & $100-160$ \\
\hline Liu et al. (2017) & $\begin{array}{l}\text { Thermo-economic analysis (multi- } \\
\text { objective optimisation) }\end{array}$ & - & $\begin{array}{l}\text { Thermal efficiency, exergy efficiency, power output, } \\
\text { capital cost }\end{array}$ & Geothermal plant & Binary ORC & Pow er & $80-95$ \\
\hline Lu et al. (2018) & Optimisation & - & Net pow er output & Geothermal plant & $\begin{array}{l}\text { Single-flash system, } \\
\text { double-flash system, } \\
\text { flash-ORC system, } \\
\text { and double-flash- } \\
\text { ORC system }\end{array}$ & Pow er & 170 \\
\hline $\begin{array}{l}\text { Makhanlall et al. } \\
\text { (2015) }\end{array}$ & $\begin{array}{l}\text { Optimisation by an } \\
\text { topological methodology } \\
\text { thermodynamic tool) }\end{array}$ & & Optimal operating conditions & Geothermal plant & $\begin{array}{l}\text { Binary medium } \\
\text { grade plant }\end{array}$ & Power & $25-150$ \\
\hline $\begin{array}{l}\text { Martínez-Gomez et } \\
\text { al. (2017) }\end{array}$ & Multi-objective optimisation & - & $\begin{array}{l}\text { Maximise profitfrom energy sales, minimise risk and } \\
\text { minimise environmental impact }\left(\mathrm{CO}_{2} \text { emissions }\right)\end{array}$ & Geothermal plant & ORC & Power & 167.75 \\
\hline Marty et al. (2018) & Simultaneous optimisation & - & Net annual profit & $\begin{array}{l}\text { ORC plant, district } \\
\text { heating plant and a } \\
\text { few consumers }\end{array}$ & ORC & $\begin{array}{l}\text { Heat } \\
\text { and } \\
\text { Pow er }\end{array}$ & 185 \\
\hline $\begin{array}{l}\text { Mohammadzadeh } \\
\text { Bina et al. (2017) }\end{array}$ & $\begin{array}{l}\text { Thermo-economic analysis (EES } \\
\text { optimisation (multi-criteria)) }\end{array}$ & $\begin{array}{l}\text { Sabalan } \\
\text { geothermal } \\
\text { pow er plant } \\
\text { (Iran) }\end{array}$ & $\begin{array}{l}\text { Energy efficiency, exergy efficiency, net power } \\
\text { output, production cost, total cost rate }\end{array}$ & Geothermal plant & $\begin{array}{l}\text { Basic ORC (B-ORC), } \\
\text { Dual fluid ORC, } \\
\text { Regenerative ORC } \\
\text { (R-ORC), ORC w ith } \\
\text { Internal } \\
\begin{array}{l}\text { Exchanger } \\
\text { ORC) }\end{array} \\
\text { (IHE- } \\
\end{array}$ & Pow er & 165 \\
\hline $\begin{array}{l}\text { Mohammadzadeh } \\
\text { Bina et al. (2018) }\end{array}$ & $\begin{array}{l}\text { Exergoeconomic analysis and } \\
\text { optimisation }\end{array}$ & $\begin{array}{l}\text { Sabalan } \\
\text { geothermal } \\
\text { pow er plant } \\
\text { (Iran) }\end{array}$ & Net pow er output & Geothermal plant & $\begin{array}{l}\text { Single and Double } \\
\text { flash cycles }\end{array}$ & Pow er & $\begin{array}{l}149- \\
242.96\end{array}$ \\
\hline Mosaffa et al. (2017) & $\begin{array}{l}\text { Thermodynamic and economic } \\
\text { analysis (optimisation) }\end{array}$ & - & $\begin{array}{l}\text { Maximise energy and exergy efficiency levels, } \\
\text { minimise total product unit cost }\end{array}$ & Geothermal plant & 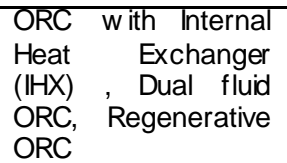 & Power & $160-180$ \\
\hline
\end{tabular}




\begin{tabular}{|c|c|c|c|c|c|c|c|}
\hline Study & Methodology & $\begin{array}{l}\text { Assessment } \\
\text { area/region or } \\
\text { plant site }\end{array}$ & Objective function & Energy system & Plant type & $\begin{array}{l}\text { Energy } \\
\text { Gener- } \\
\text { ation }\end{array}$ & $\begin{array}{l}\text { Brine } \\
\text { tempera- } \\
\text { ture }\end{array}$ \\
\hline $\begin{array}{l}\text { Nakomcic- } \\
\text { Smaragdakis et al. } \\
(2016)\end{array}$ & $\begin{array}{l}\text { 1. Determination } \\
\text { geomorphological, of } \\
\text { geophysical, hydrogeological and } \\
\text { hydrothermal characteristics of the } \\
\text { area; 2. Analysis of physicochemical } \\
\text { characteristics of geothermal and } \\
\text { mineral waters, as well as drill's } \\
\text { capacity; 3. Possible applications of } \\
\text { the geothermal fluid are considered } \\
\text { and recommendations for direct use } \\
\text { are given }\end{array}$ & Indjija (Serbia) & - & Geothermal plant & - & Heat & - \\
\hline $\begin{array}{l}\text { Østergaard et al. } \\
(2010)\end{array}$ & $\begin{array}{l}\text { Analysing scenario for supplying } \\
\text { Aalborg through renew able energies } \\
\text { on the basis of the EnergyPLAN } \\
\text { model }\end{array}$ & $\begin{array}{l}\text { Aalborg } \\
\text { (Denmark) }\end{array}$ & - & $\begin{array}{l}\text { Energy system of } \\
\text { the municipality } \\
\text { Aalborg }\end{array}$ & - & Heat & - \\
\hline $\begin{array}{l}\text { Østergaard \& Lund } \\
(2011)\end{array}$ & $\begin{array}{l}\text { Analysing scenario for supplying } \\
\text { Frederikshavn through renew able } \\
\text { energies on the basis of the } \\
\text { EnergyPLAN model }\end{array}$ & $\begin{array}{l}\text { Frederikshavn } \\
\text { (Denmark) }\end{array}$ & - & $\begin{array}{l}\text { Energy system of } \\
\text { the municipality } \\
\text { Frederikshavn }\end{array}$ & - & Heat & - \\
\hline $\begin{array}{l}\text { Pambudi et al. } \\
\text { (2014) }\end{array}$ & Optimisation & $\begin{array}{l}\text { Dieng } \\
\text { Geothermal } \\
\text { Pow er Plant } \\
\text { (Indonesia) }\end{array}$ & Energy exergy flow and efficiency & Geothermal plant & Single flash binary & Pow er & 18-179.9 \\
\hline $\begin{array}{l}\text { Pambudi et al. } \\
\text { (2018) }\end{array}$ & $\begin{array}{l}\text { Thermodynamic and silica scaling } \\
\text { analysis }\end{array}$ & $\begin{array}{l}\text { Dieng } \\
\text { Geothermal } \\
\text { Pow er Plant } \\
\text { (Indonesia) }\end{array}$ & Increase capacity, reduce the impact of silica scaling & Geothermal plant & $\begin{array}{l}\text { Single flash binary, } \\
\text { double flash binary }\end{array}$ & Pow er & 116.4 \\
\hline $\begin{array}{l}\text { Peña-Lamas et al. } \\
\text { (2018) }\end{array}$ & Optimisation & - & $\begin{array}{l}\text { Structure of the cycle, operating conditions and best } \\
\text { fluid }\end{array}$ & Geothermal plant & Binary ORC & Power & $\begin{array}{l}164.34- \\
170\end{array}$ \\
\hline Pollet et al. (2018) & Optimisation & - & Total energy output & Geothermal plant & ORC & Pow er & $120-150$ \\
\hline $\begin{array}{l}\text { Shengjun et al. } \\
(2011)\end{array}$ & $\begin{array}{l}\text { Parametric optimisation and } \\
\text { performance analysis }\end{array}$ & - & $\begin{array}{l}\text { Thermal efficiency, exergy efficiency, recovery } \\
\text { efficiency, heat exchanger area per unit power output } \\
\text { and the levelized energy cost }\end{array}$ & Geothermal plant & $\begin{array}{l}\text { Subcritical ORC and } \\
\text { transcritical power } \\
\text { cycle }\end{array}$ & Pow er & $80-100$ \\
\hline $\begin{array}{l}\text { Sigurdardottir et al. } \\
(2015)\end{array}$ & $\begin{array}{l}\text { Lumped parameter modelling (LPM) } \\
\text { combined w ith a mixed integer linear } \\
\text { programming (MLP) }\end{array}$ & $\begin{array}{l}\text { Laugarnes } \\
\text { geothermal } \\
\text { system } \\
\text { (South-West } \\
\text { lceland) }\end{array}$ & 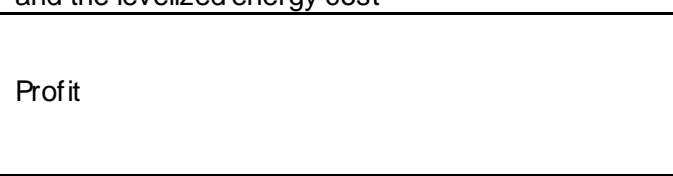 & $\begin{array}{l}\text { Geothermal } \\
\text { reservoir }\end{array}$ & Cycic & Heat & 127.55 \\
\hline Sun et al. (2017) & $\begin{array}{l}\text { Thermodynamic } \\
\text { (parametric analysis by means of } \\
\text { genetic algorithm) }\end{array}$ & - & $\begin{array}{l}\text { Turbine high-level inlet pressure and temperature, } \\
\text { turbine low-level inlet pressure }\end{array}$ & Geothermal plant & $\begin{array}{l}\text { Double-pressure } \\
\text { ORC }\end{array}$ & Pow er & 120 \\
\hline Sun et al. (2018) & Thermodynamic optimisation & & Evaporation temperature and net pow er output & Geothermal ORC & ORC & \begin{tabular}{|l} 
Pow er \\
\end{tabular} & $100-150$ \\
\hline $\begin{array}{l}\text { Sveinbjörnsson et } \\
\text { al. (2017) }\end{array}$ & $\begin{array}{l}\text { Energy supply modelling using the } \\
\text { Sifre tool }\end{array}$ & $\begin{array}{l}\text { Sonderborg } \\
\text { Municipality } \\
\text { (Denmark) }\end{array}$ & $\begin{array}{l}\text { Operating expenses of the specified energy demand } \\
\text { during all time steps }\end{array}$ & $\begin{array}{l}\text { Energy system of } \\
\text { the municipality } \\
\text { Sonderborg }\end{array}$ & - & - & - \\
\hline
\end{tabular}




\begin{tabular}{|c|c|c|c|c|c|c|c|}
\hline Study & Methodology & $\begin{array}{l}\text { Assessment } \\
\text { area/region or } \\
\text { plant site }\end{array}$ & Objective function & Energy system & Plant type & $\begin{array}{l}\text { Energy } \\
\text { Gener- } \\
\text { ation }\end{array}$ & $\begin{array}{l}\text { Brine } \\
\text { tempera- } \\
\text { ture }\end{array}$ \\
\hline $\begin{array}{l}\text { van Erdew eghe et } \\
\text { al. (2018) }\end{array}$ & Thermodynamic optimisation & - & Eectrical pow er output & $\begin{array}{l}\text { Combined heat- } \\
\text { and-pow er (CHP) } \\
\text { configurations }\end{array}$ & ORC & $\begin{array}{l}\text { Heat } \\
\text { and } \\
\text { Pow er }\end{array}$ & $110-150$ \\
\hline $\begin{array}{l}\text { van Erdew eghe et } \\
\text { al. (2019) }\end{array}$ & Tw o-step optimisation & $\begin{array}{l}\text { Balmatt site, } \\
\text { Belgium }\end{array}$ & $\begin{array}{l}\text { Design case: Net present value } \\
\text { Off-Design case: Net electrical pow er output }\end{array}$ & Geothermal plant & ORC & Pow er & $110-150$ \\
\hline $\begin{array}{l}\text { Walraven et al. } \\
\text { (2015) }\end{array}$ & $\begin{array}{l}\text { Optimisation with different types of } \\
\text { cooling systems }\end{array}$ & Belgium & Levelized cost of electricity & Geothermal plant & ORC & Pow er & $100-150$ \\
\hline Wu et al. (2017) & $\begin{array}{l}\text { Thermodynamic analysis and } \\
\text { performance optimisation } \\
\text { (parametric optimisation via pattern } \\
\text { search algorithm (PSA)) }\end{array}$ & - & $\begin{array}{l}\text { Turbine inlet temperature, turbine inlet pressure, } \\
\text { pow er output }\end{array}$ & Geothermal plant & $\begin{array}{l}\text { Transcritical Power } \\
\text { Cycle (TPC) }\end{array}$ & Pow er & $100-150$ \\
\hline Yang \& Yeh (2015) & Economic performance optimisation & - & Net pow er output & Geothermal plant & $\begin{array}{l}\text { TranscriticalRankine } \\
\text { Cycle (TRC) }\end{array}$ & Pow er & $\begin{array}{l}44.13- \\
66.02\end{array}$ \\
\hline Yilmaz (2017) & $\begin{array}{l}\text { Thermo-economic optimisation using } \\
\text { genetic algorithm method }\end{array}$ & - & Cost optimal exergetic efficiency & Geothermal plant & $\begin{array}{l}\text { Combined flash- } \\
\text { binary }\end{array}$ & Pow er & $150-159$ \\
\hline Zare (2015) & $\begin{array}{l}\text { Thermodynamic } \\
\text { exergoeconomic optimisation } \quad \text { with } \\
\text { ow n models \& profitability evaluation }\end{array}$ & - & $\begin{array}{l}\text { Optimisation: total capital investment and payback } \\
\text { period }\end{array}$ & Geothermal plant & $\begin{array}{l}\text { ORC-based binary } \\
\text { pow er plant }\end{array}$ & Pow er & $160-170$ \\
\hline $\begin{array}{l}\text { Zhao \& Wang } \\
\text { (2016) }\end{array}$ & $\begin{array}{l}\text { Exergoeconomic analysis and } \\
\text { optimisation }\end{array}$ & - & $\begin{array}{l}\text { Exergoeconomic: Minimise levelized cost per unit of } \\
\text { exergy; Thermodynamic: maximise exergy efficiency. }\end{array}$ & Geothermal plant & $\begin{array}{l}\text { Flash-binary ORC } \\
\text { cycle }\end{array}$ & Pow er & 200 \\
\hline
\end{tabular}




\section{A2. Data tables on deep geothermal projects}

Table A2: Data on German deep geothermal projects (Agemar etal.2014; Enerchange 2018; Eyerer et al. 2017). If more sources than Age mar et al. (2014), Enerchange (2018) and Eyerer et al. (2017) were used, these are indicated in the table column "sources". If the maximum wellhead temperature of the model is less than the calculated temperature, it is coloured red.

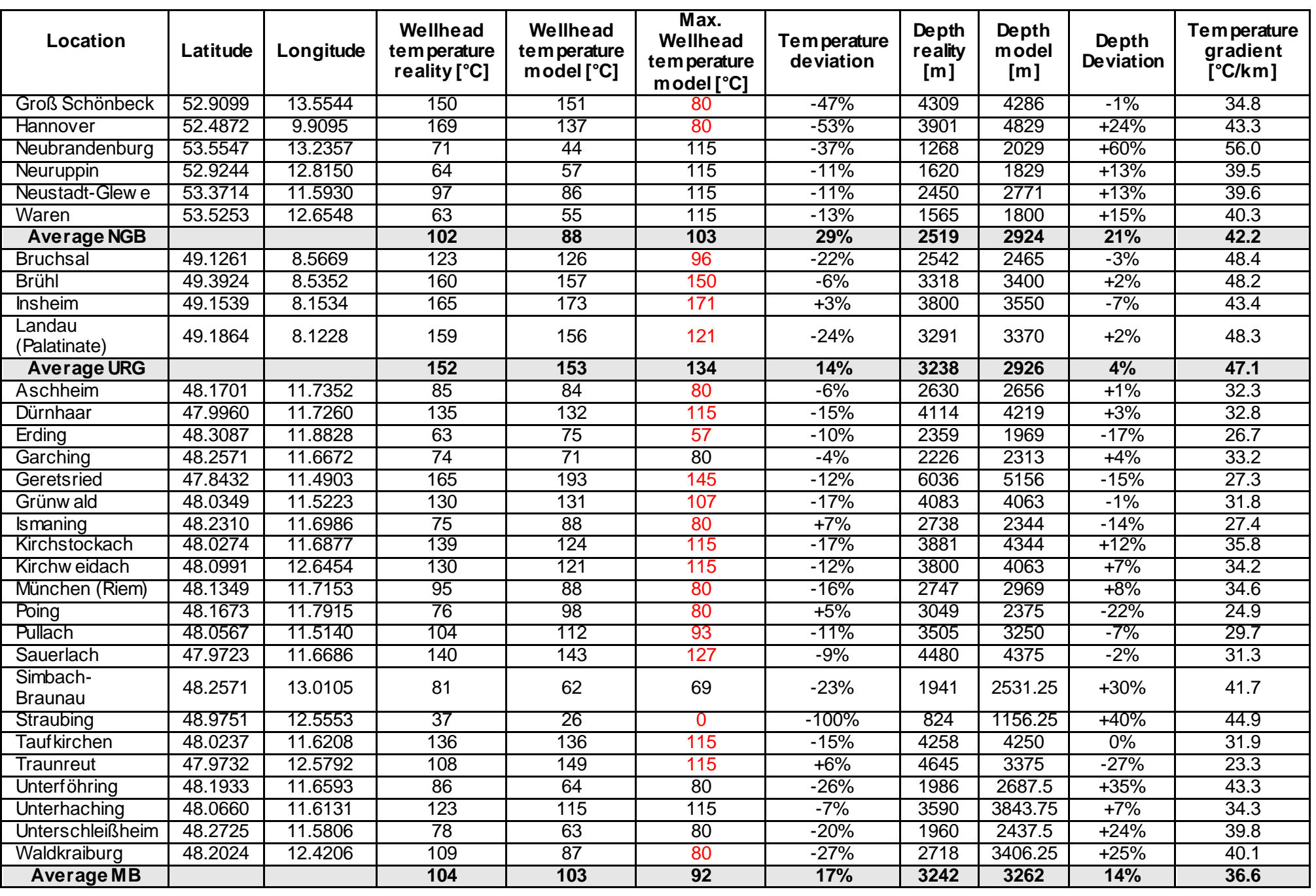


Table A2 (continued)

\begin{tabular}{|c|c|c|c|c|c|c|c|}
\hline Location & $\begin{array}{c}\text { Injection } \\
\text { Tem perature }\left[{ }^{\circ} \mathrm{C}\right]\end{array}$ & $\begin{array}{l}\text { Forw ard } / \text { return } \\
\text { tem perature }\left[{ }^{\circ} \mathrm{C}\right]\end{array}$ & $\begin{array}{c}\text { Volumetric } \\
\text { flow rate } \\
{[\mathrm{L} / \mathrm{s}]}\end{array}$ & $\begin{array}{l}\text { Nom inal power } \\
\text { (electrical) [MW] }\end{array}$ & $\begin{array}{l}\text { Nom inal Power } \\
\text { (thermal) [MW] }\end{array}$ & $\begin{array}{c}\text { Calculated electrical } \\
\text { efficiency [\%] }\end{array}$ & Sources \\
\hline Groß Schönbeck & & & 21 & 0.07 & 7 & & \\
\hline Hannover & & & 7 & 0 & 2 & & \\
\hline Neubrandenburg & & $65 / 35$ & $11-28$ & 0 & 3.8 & & Schallenberg (1996) \\
\hline Neuruppin & & & 14 & 0 & 2.1 & & \\
\hline Neustadt-Glew e & & $90 / 60$ & $11-33$ & 0.2 & $5 \longdiv { 6 . 5 }$ & & Schallenberg (1996) \\
\hline Waren & & $70 / 50$ & 17 & 0 & 3.6 & & \\
\hline Average NGB & & & $14-20$ & & & & \\
\hline Bruchsal & 60 & $90 / 65$ & 24 & 0.55 & 5.5 & & Eyerer et al. (2017) \\
\hline \multicolumn{8}{|l|}{ Brühl } \\
\hline Insheim & 70 & & 85 & 4.8 & 0 & 15 & \\
\hline Landau (Palatinate) & 50 & $70 / 40$ & 70 & 3.8 & 6 & & Eyerer et al. (2017) \\
\hline Average URG & & & 60 & & & 15 & \\
\hline Aschheim & & & 75 & 0 & 27 & & \\
\hline Dürnhaar & 45 & & 130 & $5.5 / 7$ & 0 & 15 & \\
\hline Erding & & & 48 & 0 & $34 / 10.2$ & & \\
\hline Garching & & & 100 & 0 & $15 / 8$ & & \\
\hline \multicolumn{8}{|l|}{ Geretsried } \\
\hline Grünw ald & & $120 / 65$ & 150 & 4.5 & 50 & & Bauer et al. (2014) \\
\hline Ismaning & & & 85 & 0 & 10 & & \\
\hline München (Riem) & & & 75 & 0 & 10 & & \\
\hline Poing & & & 80 & 0 & 9 & & \\
\hline Pullach & & & 71 & 0 & 15 & & \\
\hline Sauerlach & 45 & $90-105 / 60$ & 110 & 4 & 5 & & \\
\hline Simbach-Braunau & & & 80 & 0.2 & 8 & & \\
\hline Straubing & & & 45 & 0 & 4.1 & & \\
\hline Taufkirchen & & $115 / 70$ & 120 & 4.3 & 35 & & \\
\hline Traunreut & 55 & $100 / 65$ & 150 & 5 & 12 & & \\
\hline Unterföhring & & & 75 & 0 & 10 & & \\
\hline Unterhaching & 60 & $80-110 / 50-60$ & 150 & 3.4 & 38 & & Eyerer et al. (2017) \\
\hline Unterschleißheim & & & 90 & 0 & $28 / 8$ & & \\
\hline Waldkraiburg & & & 65 & 4.8 & 14 & & \\
\hline Average MB & & & 95 & & & 12.5 & \\
\hline
\end{tabular}




\begin{tabular}{|c|c|c|c|c|c|c|c|c|c|c|}
\hline Location & $\begin{array}{c}\text { Total } \\
\text { investment } \\
\text { reality }[\mathrm{m} . €]\end{array}$ & $\begin{array}{c}\text { Total } \\
\text { investment } \\
\text { model } \\
{[\mathrm{m} . €]}\end{array}$ & $\begin{array}{c}\text { Total } \\
\text { investment } \\
\text { deviation }\end{array}$ & $\begin{array}{c}\text { Investment } \\
\text { for drilling } \\
{[\mathrm{m} . €]}\end{array}$ & $\begin{array}{c}\text { Tnvestment } \\
\text { distric } \\
\text { heating } \\
\text { network } \\
\text { [m. } €]\end{array}$ & $\begin{array}{c}\text { Tnvestment } \\
\text { for plant } \\
\text { process } \\
{[\mathrm{m} . €]}\end{array}$ & $\begin{array}{l}\text { Plant } \\
\text { Process }\end{array}$ & $\underset{\text { year }}{\text { Commissioning }}$ & $\begin{array}{l}\text { Number } \\
\text { of wells }\end{array}$ & Sources \\
\hline GroßSchönbeck & 12.1 & 38 & $+212 \%$ & & & & ORC & Testing phase & 2 & GTN (2012a) \\
\hline Hannover & 15 & 17 & $+15 \%$ & & & & & development & 1 & Bundesverband Geothermie (2018) \\
\hline Neubrandenburg & & 21 & & & & & & 1987 & 3 & Bundesverband Geothermie (2018) \\
\hline Neuruppin & & 16 & & & & & & 2007 & 2 & Bundesverband Geothermie (2018) \\
\hline Neustadt-Glew e & 10.8 & 24 & $+122 \%$ & 1.7 & 1.8 & 3.2 & ORC & 2003 & 2 & GTN (2012b); Enerchange (2009) \\
\hline Waren & & 27 & & & & & & 1984 & 4 & \\
\hline Average NGB & 13 & 24 & $116 \%$ & & & & & & 2.3 & \\
\hline Bruchsal & 17 & 24 & $+43 \%$ & 8.1 & & & Kalina & 2001 & 2 & \\
\hline Brühl & & & & & & & & development & & \\
\hline Insheim & 50 & 40 & $-20 \%$ & & & & ORC & 2012 & 2 & Eyerer et al. (2017) \\
\hline Landau (Palatinate) & 20 & 39 & $+93 \%$ & & & & ORC & 2007 & 2 & \\
\hline Averaqe URG & 19 & 34 & $52 \%$ & & & & & & 2 & \\
\hline Aschheim & 60 & 45 & $-24 \%$ & & & & & 2009 & 2 & BundesverbandGeothermie (2018) \\
\hline Dürnhaar & 60 & 50 & $-17 \%$ & & & & & 2012 & 2 & $\begin{array}{c}\text { Bundesverband Geothermie (2018); } \\
\text { Eyerer et al. (2017) }\end{array}$ \\
\hline Erding & 18.7 & 51 & $+172 \%$ & & & & & 1998 & 2 & Bundesverband Geothermie (2018) \\
\hline Garching & & 32 & & 13 & & & & 2011 & 2 & Bundesverband Geothermie (2018) \\
\hline Geretsried & & & & & & & & development & & \\
\hline Grünw ald & 150.4 & 92 & $-39 \%$ & & 53.8 & & ORC & 2011 & 2 & Erdw ärme Grünw ald GmbH (2013) \\
\hline Ismaning & 71.6 & 36 & $-50 \%$ & 18 & 41 & & & 2012 & 3 & \\
\hline Kirchstockach & 62 & 44 & $-30 \%$ & 23 & & & ORC & 2013 & 2 & Eyerer et al. (2017) \\
\hline Kirchw eidach & & 40 & & & & & & 2012 & 2 & BundesverbandGeothermie (2018) \\
\hline München (Riem) & & 31 & & & & & & 2004 & $\frac{5}{2}$ & Bundesverband Geothermie (2018) \\
\hline Poing & & 30 & & & & & & 2013 & 2 & \\
\hline Pullach & & 47 & & 9 & & & & 2005 & 3 & \\
\hline Sauerlach & 90 (initially 25) & 62 & $-31 \%$ & & & & ORC & 2014 & 3 & $\begin{array}{c}\text { Bundesverband Geothermie (2018; } \\
\text { Zeitungsverlag tz (2014) }\end{array}$ \\
\hline Simbach-Braunau & 21 & 24 & $+14 \%$ & & & & ORC & 2001 & 2 & Bundesverband Geothermie (2018) \\
\hline Straubing & 12 & 16 & $+33 \%$ & & & & & 1999 & 2 & Bundesverband Geothermie (2018) \\
\hline Taufkirchen & 65 & 78 & $+20 \%$ & & & & Kalina & $\begin{array}{l}\text { Testing phase } \\
(2014)\end{array}$ & 2 & $\begin{array}{c}\text { Bundesverband Geothermie (2018); } \\
\text { Eyerer et al. (2017) }\end{array}$ \\
\hline Traunreut & 80 & 62 & $-23 \%$ & & & & ORC & 2014 & 2 & \\
\hline Unterföhring & 37.5 & 36 & $-5 \%$ & 12.5 & 14.5 & & & 2009 & 4 & \\
\hline Unterhaching & 80 & 73 & $-9 \%$ & & 48 & 16 & Kalina & 2009 & 2 & Geothermie Unterhaching (2017) \\
\hline Unterschleißheim & 22 & 44 & $+99 \%$ & & & & & 2013 & 2 & Bundesverband Geothermie (2018) \\
\hline Waldkraiburg & 12 & 46 & $+281 \%$ & & & & & 2012 & 2 & $\begin{array}{c}\text { OVB24 GmbH (2009); Bundesverband } \\
\text { Geothermie (2013) }\end{array}$ \\
\hline Average MB & 55 & 47 & $56 \%$ & & & & & & 2.3 & \\
\hline
\end{tabular}




\section{A3. Model deviation compared to reality}

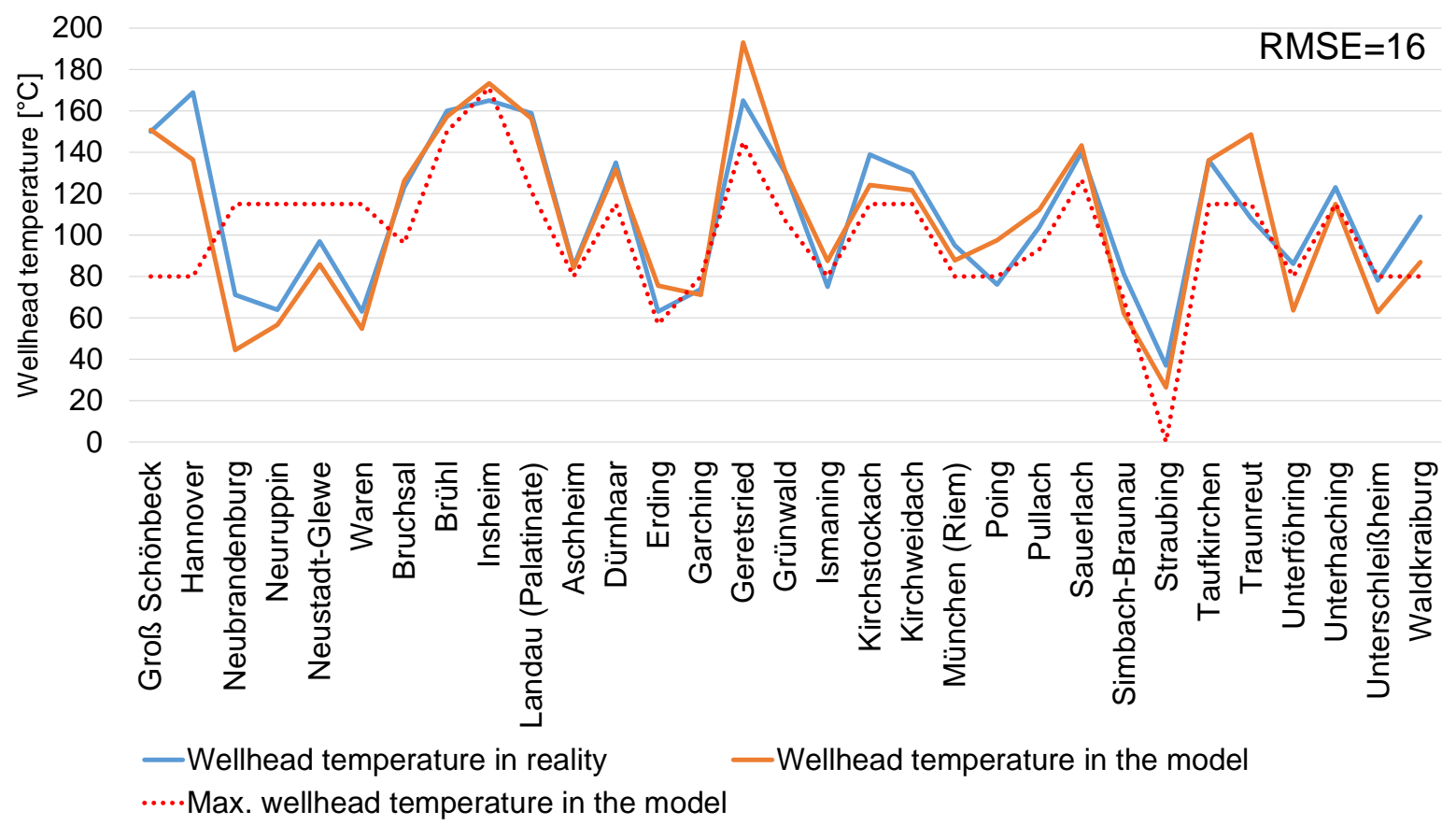

Figure A1: Wellhead temperature of geothermal projects in reality compared to the model (cf. columns "Wellhead temperature reality", "Wellhead tem perature model" and "Max. wellhead temperature model" in Table A 2 for precise values). For a better analysis of the colours in this figure, please refer to the online version of the paper.

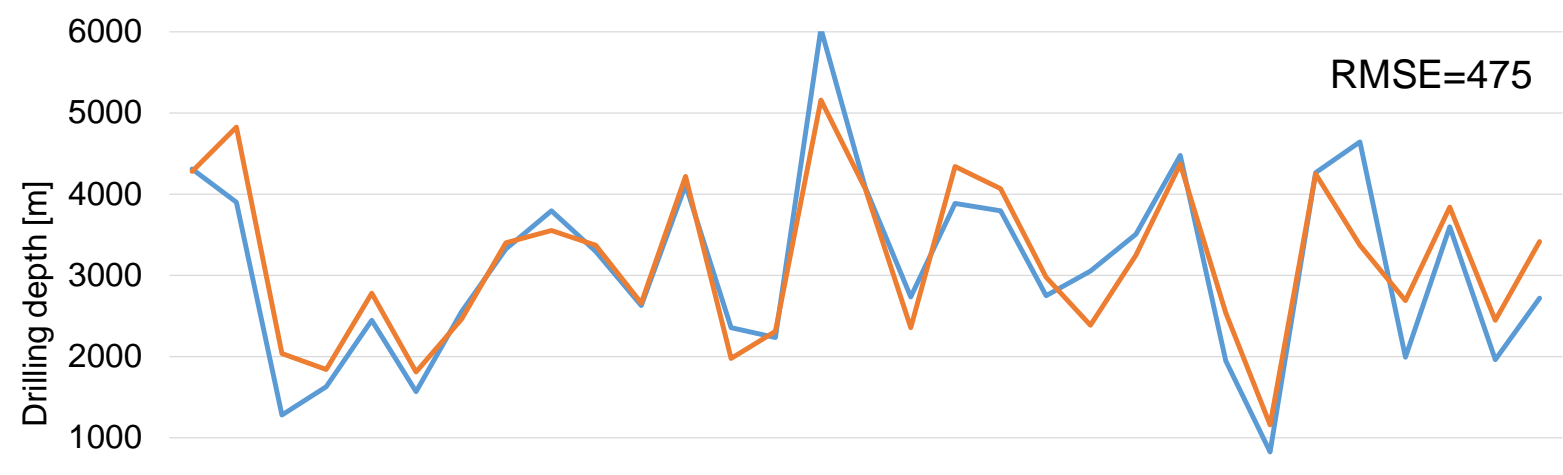

0

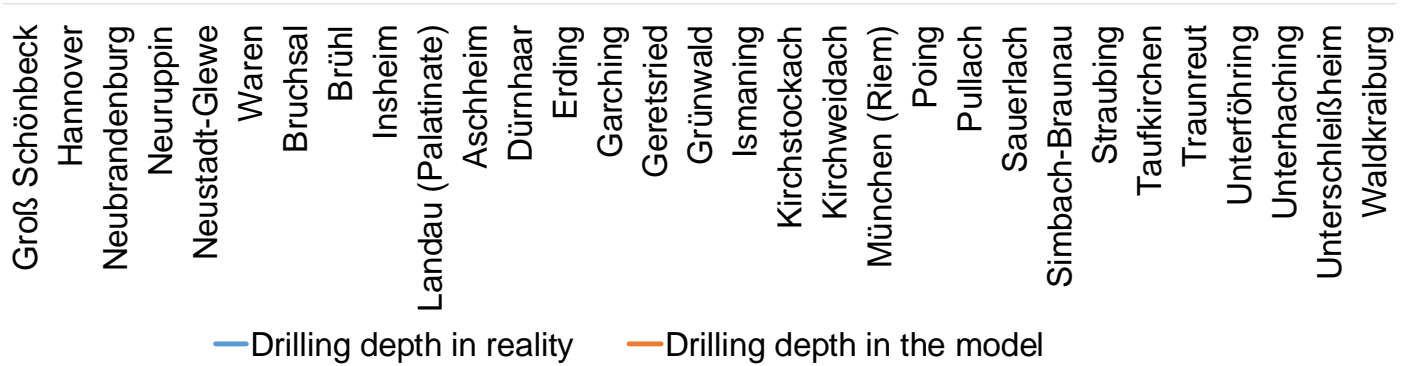

Figure A2: Drilling depth of geothermal projects in reality compared to the model. (cf. columns "Depth reality" and "Depth model" in Table A2 for precise values). For a better analysis of the colours in this figure, please refer to the online version of the paper. 


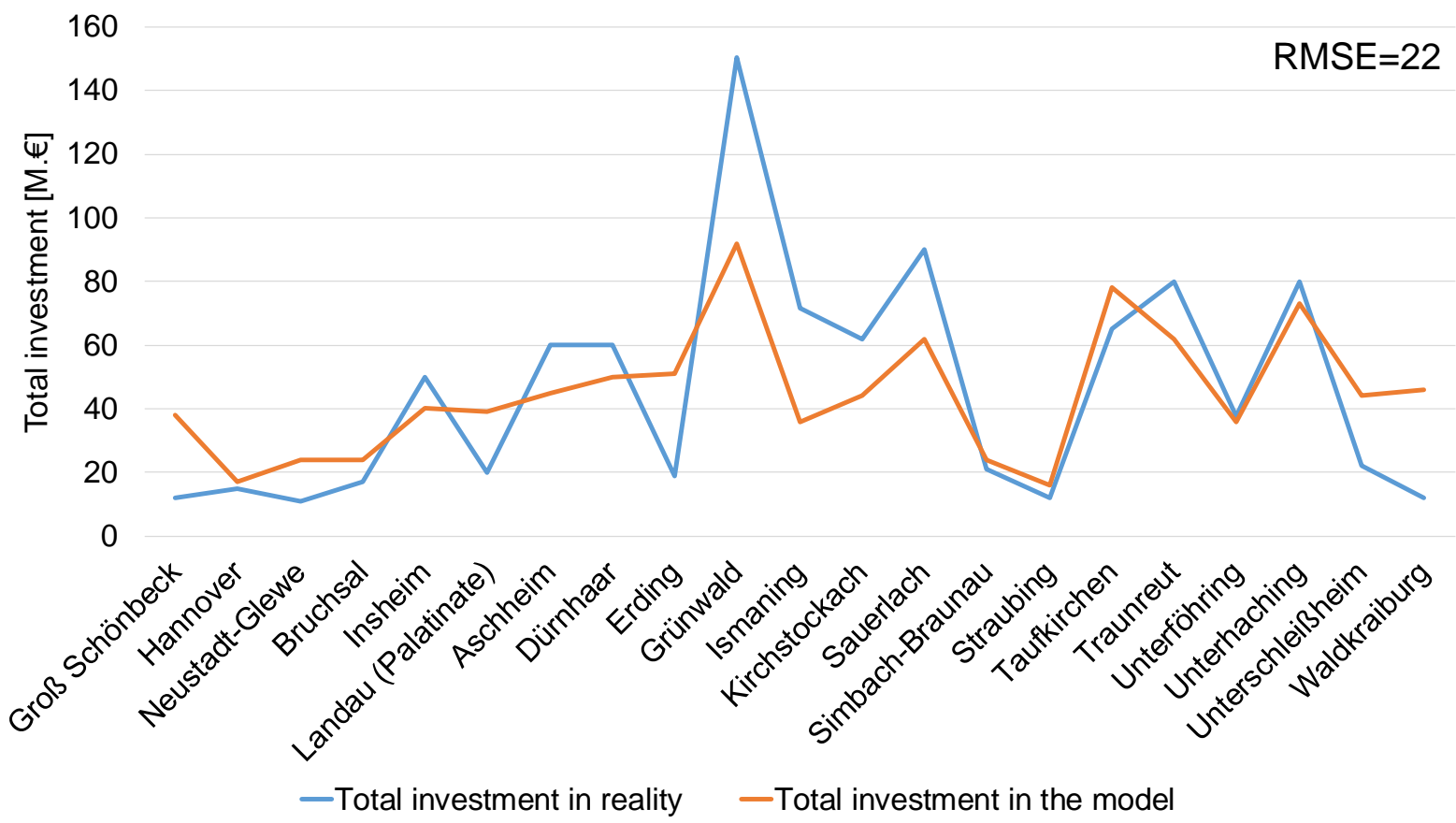

Figure A3: Total investment of geothermal projects in reality compared to the model. (cf. columns "Total investment reality" and "Total investment model" in Table A2 for precise values). For a better analysis of the colours in this figure, please refer to the online version of the paper.

\section{A4. Further economic assessment}

The purchase values for properties $C_{P}$ in German municipalities are given in Statistisches Bundesamt (2016a) divided into municipal size classes, i. e. depending on the population in the municipality. A distinction is made here between developed building land, undeveloped building land and other building land. Other building land can be developed building land and undeveloped building land, but differs from both in its fixed use to date. It includes industrial land, land for transport and open spaces (Statistisches Bundesamt2016b). As commercial and industrial sites are included in the other building land, it is assumed that the geothermal plants will be built on this kind of land. Figure A4 shows the cost structure of other building land for different municipality sizes (Statistisches Bundesamt 2016a).

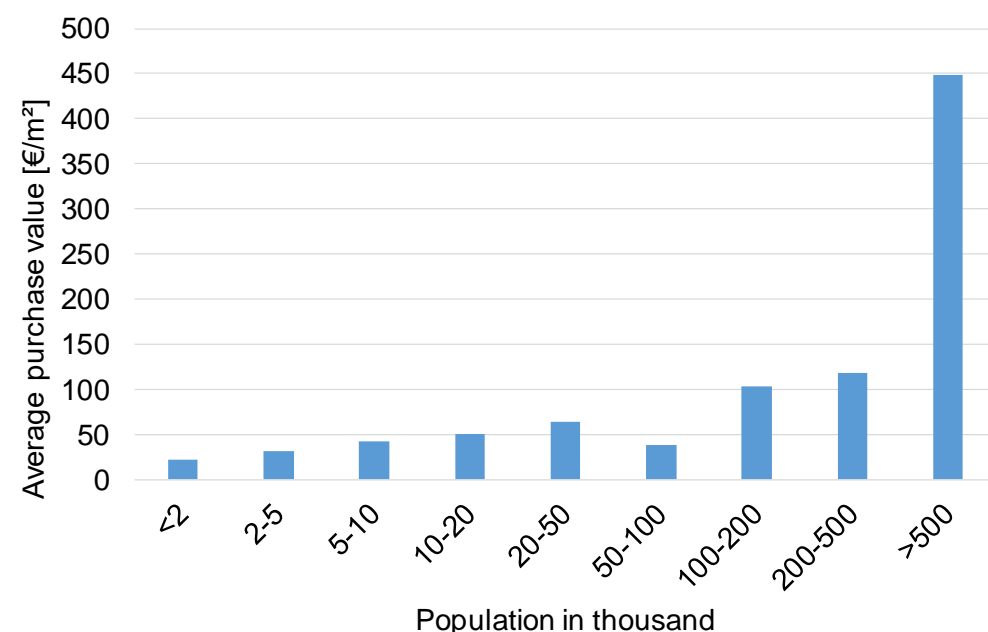

Figure A4: Average purchase value for other building land for different municipality sizes (Statistisches Bundesamt2016a). 
The figure shows that the land prices can differ significantly from the $60 € / \mathrm{m}^{2}$ assumed in Schlagermann (2014). With the exception of the outlier in municipalities with between 50,000 and 100,000 inhabitants, property costs increase with the number of inhabitants, probably due to the scarcity of free space in municipalities with many inhabitants. However, as Schmalwasser \& Brede (2015) show, land prices depend more on population density. Therefore, the average population densities are determined for the municipal size classes in Table A3 by using the municipality data from Statistisches Bundesamt (2017b) and the prices are set for the resulting population density classes.

Table A3: Costs for other building land depending on the number of inhab itants of the municipality.

\begin{tabular}{|l|l|l|l|l|l|l|l|l|l|}
\hline Population (in thsd.) & $<2$ & $2-5$ & $5-10$ & $10-20$ & $20-50$ & $50-100$ & $\begin{array}{l}100- \\
200\end{array}$ & $200-500$ & $>500$ \\
\hline $\begin{array}{l}\text { Mean population density in } \\
\text { municipality } \\
{\left[\text { Inhabitants/km }{ }^{2}\right]}\end{array}$ & 80 & 170 & 245 & 380 & 565 & 885 & 1385 & 1695 & 2700 \\
\hline Purchase value [€/m $\left.{ }^{2}\right]$ & 21.5 & 31.0 & 42.0 & 50.5 & 64.0 & 37.5 & 103.0 & 117.5 & 449.0 \\
\hline
\end{tabular}

Finally, the cost of land and infrastructure $C_{2}$ can be estimated using the following equation:

$$
\begin{aligned}
\boldsymbol{C}_{\mathbf{2}} & =C_{P} \cdot\left(\boldsymbol{A}_{\boldsymbol{D}}+\boldsymbol{A}_{\boldsymbol{e l}}+\boldsymbol{A}_{\boldsymbol{t h}}\right) \\
& =C_{P} \cdot\left(2400 \mathrm{~m}^{2} \cdot \boldsymbol{b}_{\boldsymbol{G P}}+\left(2000 \mathrm{~m}^{2} \cdot \boldsymbol{b}_{\boldsymbol{P P}}+0.25 \frac{\mathrm{m}^{2}}{\mathrm{~kW}_{\mathrm{el}}} \cdot \boldsymbol{P}_{\boldsymbol{e l , \text { max }}}\right)+\left(100 \mathrm{~m}^{2} \cdot \boldsymbol{b}_{\boldsymbol{D} \boldsymbol{H} P}+0.01 \frac{\mathrm{m}^{2}}{\mathrm{~kW}_{\mathrm{th}}} \cdot \dot{\boldsymbol{Q}}_{\boldsymbol{t h}, \text { max }}\right)\right)
\end{aligned}
$$

$A_{D}$ is the area required for the well site, $A_{e l}$ for the power generation plant and $A_{t h}$ for the district heating plant.

The pumps in a low-temperature geothermal plant consume approximately $D_{p}=30 \%$ of the gross output (Quoilin et al. 2013; Kraml \& Walzer 2008). Therefore, the demand $D_{\text {pump }}$ has to be added to the electricity demand $D_{e}$ if a geothermal plant is built during the optimisation in order to determine the total electricity demand $D_{e l, t o t a l}$ :

$$
\boldsymbol{D}_{\text {el,total }}(t)=\boldsymbol{D}_{\text {el }}(t)+\boldsymbol{D}_{\text {pump }}(t)
$$

with

$$
\boldsymbol{D}_{\text {pump }}(t)=D_{p} \cdot\left(\boldsymbol{P}_{\text {el }}(t)+\dot{\boldsymbol{Q}}_{\boldsymbol{t h}}(t) \cdot \frac{\eta_{e l}}{\eta_{t h}}\right)
$$

As a conservative estimate, the assumption is made that the required amount $D_{\text {pump }}$ is not yet included in the calculation to determine $\eta_{\text {th }}$ in Ozgener \& Ozgener (2009). The nominal power $P_{\text {pump }}$ of the pump is determined via Eq. A4 with a pump efficiency $\eta_{\text {pump }}$ of 0.95 .

$$
\boldsymbol{P}_{\text {pump }} \geq \boldsymbol{D}_{\text {pump }}(t) \cdot \eta_{\text {pump }}
$$

Eyerer et al. (2017) specify the installation depth of the pumps in the production wells for eight German power plants. With the help of the average value of $700 \mathrm{~m}$, the costs for the production well pump $C_{4}$ can then be calculated according to Eq. A5 (Schlagermann 2014).

$$
\boldsymbol{C}_{\mathbf{4}}=15.7 \frac{€}{\mathrm{~kW}} \cdot \boldsymbol{P}_{\text {pump }}+98,500 € \cdot \boldsymbol{b}_{\boldsymbol{G P}}
$$

The costs for the thermal water circuit $C_{5}$ are determined as a function of the volumetric flow rate rate $\dot{V}_{B}$, assuming a constant length of the circuit (Jancik \& Kupfermann 2014):

$$
\boldsymbol{C}_{5}=5,000 \frac{€ \cdot \mathrm{s}}{\mathrm{l}} \cdot \dot{V}_{B}+600,000 € \cdot \boldsymbol{b}_{\boldsymbol{G P}}
$$


For the ORC plant and the grid connection, a linear cost function $C_{6}$ is assumed according to the values from Jancik \& Kupfermann (2014), Campos Rodríguez et al. (2013) and RubioMaya et al. (2016):

$$
\boldsymbol{C}_{\mathbf{6}}=2,470 \frac{€}{\mathrm{~kW}} \cdot \boldsymbol{P}_{\text {el } \boldsymbol{l} \text { max }}+14,100 € \cdot \boldsymbol{b}_{\boldsymbol{P P}}
$$

The costs for project management, control and finance planning as well as other capital-related costs such as insurance, seismic monitoring and public relations $C_{8}$ are determined according to the following equation (Schlagermann 2014):

$C_{8}=0.08 \cdot\left(C_{1}+C_{2}+C_{3}+C_{4}+C_{5}+C_{6}+C_{7}\right)+0.035 \cdot C_{3}+0.005 \cdot\left(C_{4}+C_{5}+C_{6}+C_{7}\right)+650,000 € \cdot b_{G P} A 8$

\section{A4.1. Total investment in model and reality}

The total investment is determined for comparison with the real investments for the projects in Table A2. Since the costs for district heating depend on the population density and thus on the individual case of consideration, an equation is derived from (Jancik \& Kupfermann 2014) for the calculation of the total investment in Table A2:

$$
\boldsymbol{f}\left(\dot{\boldsymbol{Q}}_{\boldsymbol{t h}, \boldsymbol{m a x}}\right)=815 € / \mathrm{kW}_{\mathrm{th}} \cdot \dot{\boldsymbol{Q}}_{\boldsymbol{t h}, \boldsymbol{m a x}}-130,000 €
$$

The more accurate investment calculation for the district heating plant from section 3.4.2 cannot be used in this comparison but is used in the optimisations. The total investment was determined only for those geothermal plants for which sufficient information was available. By comparing the total investment calculated in the model and in reality, it is noticeable that the total investment is usually overestimated in the model (40\% on average). However, a RMSE of $22 \mathrm{M} €$ is achieved (cf. Figure A3). This conservative assessment is taken over for the optimisation.

\section{A4.2. Demand-related costs, operating costs and other variable costs}

The yearly costs for working fluid and other demand-related resources $C_{D R}$ are applied in accordance with Schlagermann (2014):

$$
\boldsymbol{C}_{\boldsymbol{D R}}(\boldsymbol{a})=0.01 \cdot\left(\boldsymbol{C}_{\mathbf{4}}+\boldsymbol{C}_{\mathbf{5}}+\boldsymbol{C}_{\mathbf{6}}+\boldsymbol{C}_{\mathbf{7}}+150,000 € \cdot \boldsymbol{b}_{\boldsymbol{G P}}\right)
$$

The operating costs include yearly labour costs $C_{L}$, which are calculated as a function of the thermal output of the thermal water mass flow (Eyerer et al. 2017):

$$
\boldsymbol{C}_{\boldsymbol{L}}(\boldsymbol{a})=220,000 \cdot e^{5 \cdot 10^{-6} \cdot \dot{V}_{B} \cdot \rho_{W} \cdot c_{p, w} \cdot\left(\boldsymbol{T}_{P W, \text { max }}-\boldsymbol{T}_{\boldsymbol{D H P}, \text { returm }}\right)}
$$

This equation has to be linearised. However, since it depends on the temperature of the water in the production well $T_{P W, \max }$ and the injection temperature $T_{I w}$, a value must be set for $T_{I W}$. Since the influence of the injection temperature on the costs is not high, $65^{\circ} \mathrm{C}$ is set as an estimate for the safe side. This results in the following equation for labour costs:

$$
\boldsymbol{C}_{\boldsymbol{L}}(\boldsymbol{a})=380 € /{ }^{\circ} \mathrm{C} \cdot \boldsymbol{T}_{\boldsymbol{P W}, \boldsymbol{m a x}}+205,500 € \cdot \boldsymbol{b}_{G P}
$$

Other operating costs $C_{O P}$ include costs for remote monitoring and operation of seismic monitoring as well as maintenance and repair costs and other variable costs Covinclude costs for insurance and legal assistance:

$$
\begin{gathered}
\boldsymbol{C}_{\boldsymbol{O P}}(\boldsymbol{a})=61,000 € \cdot \boldsymbol{b}_{G P}+1.25 \cdot 0.005 \cdot \boldsymbol{C}_{D}+0.03 \cdot\left(\boldsymbol{C}_{\mathbf{4}}+\boldsymbol{C}_{\mathbf{5}}+\boldsymbol{C}_{\mathbf{6}}+\boldsymbol{C}_{\mathbf{7}}\right) \\
\boldsymbol{C}_{\boldsymbol{O}}(\boldsymbol{a})=0.006 \cdot\left(\boldsymbol{C}_{\mathbf{4}}+\boldsymbol{C}_{\mathbf{5}}+\boldsymbol{C}_{\mathbf{6}}+\boldsymbol{C}_{\mathbf{7}}\right)+115,900 € \cdot \boldsymbol{b}_{\boldsymbol{G P}}
\end{gathered}
$$

